\title{
EESTI AJALOOTEADUS 21. SAJANDIL: SISSEJUHATUSEKS
}

\author{
Marek TAMM \\ Tallinna Ülikool, humanitaarteaduste instituut, Narva mnt 25, 10120 Tallinn, Eesti; marek.tamm@tlu.ee \\ Artikkel pakub põhilises kvantitatiivse ülevaate Eesti ajalooteaduse arengust ja korraldusest 21. sajandi \\ esimesel kahel kümnendil. Lähemalt on vaatluse all viis teemat: esiteks kaardistatakse Eesti ajaloo- \\ teadust uurijate vaates; teiseks kirjeldatakse ajaloouurimise olulisemaid institutsioone (ülikoolid, \\ uurimiskeskused, arhiivid, muuseumid, raamatukogud ja seltsid); kolmandaks pakutakse ülevaade \\ ajalooteaduse konkurentsipõhisest rahastusest; neljandaks tutvustatakse ajaloolaste publitseerimis- \\ praktikaid ja olulisemaid kommunikatsioonikanaleid ning lõpetuseks esitatakse mõned tähelepanekud \\ Eesti ajalookirjutuse sisulistest arengusuundadest viimasel kahel aastakümnel.
}

Eesti ajalooteadus ei ole kunagi hiilanud refleksiivsusega. Põhjused on mõneti mõistetavad, sest poliitilised olud pole olnud alati soodsad ja kriitiline historiograafia on ka maailmas pigem hiljutine nähtus. Nii tulebki mõneti ootamatult tõdeda, et esimene ja viimane ulatuslikum katse Eesti ajalooteaduse saavutusi kriitiliselt hinnata pärineb täpselt poole sajandi tagant, 1970. aastast, kui ilmus Endel Lauli koostatud koguteos „Leninlik etapp eesti ajalooteaduses“. ${ }^{1}$ See tõdemus mõistagi ei tähenda, et katseid Eesti ajalookirjutuse traditsiooni uurida ja mõtestada poleks vahepealsel ajal tehtud. Aastatel 1998-2002 viidi näiteks Tiit Rosenbergi juhtimisel Tartu Ülikooli ajaloo osakonnas ellu riiklikult sihtfinantseeritud uurimisprojekt ,Eesti ajaloo historiograafia“, mille vahetu väljund kirjasõnasse on jäänud küll siiani vaoshoituks. 1999. aasta jaanuaris peeti Tartu Ülikoolis esinduslik teaduskonverents „Eesti ajalooteadus III aastatuhande künnisel“", mille ettekanded ilmusid osaliselt sama aasta Ajaloolise Ajakirja teemanumbris. ${ }^{2}$

\footnotetext{
1 Leninlik etapp eesti ajalooteaduses: Historiograafilisi artikleid. Koost ja toim E. Laul. Eesti Raamat, Tallinn, 1970. Raamat kannatab mõistagi ajastu kõikide hädade all, eriti teose esimeses pooles, ent sisaldab siiski kasutamiskõlblikku ainest teises pooles, mis kätkeb ülevaateid talurahva- ja agraarajaloo uurimisest, arheoloogiast, etnograafiast, kunstiajaloost, arhiivindusest ja ajaloobibliograafiast. Mainida tuleb ka hilisemat ettevõtmist Saksamaal - pakkuda ajalooline ülevaade baltisaksa ajalookirjutuse traditsioonist Baltikumis: Geschichte der deutschbaltischen Geschichtsschreibung. Hrsg. v. G. von Rauch. Böhlau, Köln, 1986.

2 Ajalooline Ajakiri, 1999, 1 (104). Koost T. Rosenberg. Lisaks võib mainida 2000. aasta varasügisel ilmunud Vikerkaare kaksiknumbrit (8/9), mis oli samuti pühendatud põhiosas Eesti ajalookirjutuse
} 
Viimastel kümnenditel on kirjutatud ridamisi lühemaid üksikkäsitlusi Eesti ajalooteaduse olulisematest autoritest, institutsioonidest ja teemadest nii sõjaeelses vabariigis kui ka nõukogude perioodil (sh paguluses). ${ }^{3}$ Ajaloolise suunitlusega eneserefleksiooni on täiendanud mõned suurema üldistusjõuga artiklid Eesti ajalookirjutuse keerdkäikude ja väljavaadete üle üldiselt ning eriti viimastel kümnenditel, seda nii eesti, inglise kui ka saksa keeles. ${ }^{4}$ Eneseanalüüse on sel sajandil kirjutatud samuti mõnes konkreetses ajaloouurimise valdkonnas, seda eriti arheoloogias ja kunstiajaloos. ${ }^{5}$

kriitilisele vaatlusele. Viimane arutelu jõudis Karsten Brüggemanni vahendusel ka saksakeelsete lugejate ette, vt: Wie schreibt man estnische Geschichte? Zur Forsetzung der estnischen Debatte über die eigene Geschichte. - Osteuropa, 2001, 7, A188-A200. Vt ka Brüggemann, K. Von der Renationalisierung zur Demontage nationaler Helden. Oder „Wir schreibt man estnische Geschichte? - Osteuropa, 2001, 7, 810-819.

3 Kõigile asjakohastele töödele viitamine läheks siin pikale, mistõttu mainin vaid mõningaid olulisemaid ja pikaajalisemaid uurijaid selles vallas: Jüri ja Sirje Kivimäe, Krista Kodres, Tiit Rosenberg, Jaan Undusk. Nimekirja tuleb lisada ka mõned teemakohased väitekirjad ülikoolides (Raido Kahm, Helen Lausma-Saar, Mihkel Truman jt).

4 Vt nt Jansen, E. Hajamõtteid Eesti ajaloo uurimisest. - Kleio, 1997, 1, 35-41; Kivimäe, J. Rewriting Estonian history? - National identity and history: Approaches to the writing of national history in the north-east Baltic region. Ed. by M. Branch. (Studia Fennica: Ethnologica, 6.) Finnish Literature Society, Helsinki, 1999, 205-212; Must, Ü. Estonian historical science in the 1990s. Research Evaluation, 1999, 8, 2, 77-81; Undusk, J. Ajalootõde ja metahistoorilised žestid: Eesti ajaloo mitmest moraalist. - Tuna, 2000, 2, 114-130; Rosenberg, T. Ajaloo raiumisest raamatusse: Eesti ajaloo suurest narratiivist. - Raamatu osa Eesti arengus: Eesti Raamatu Aasta avakonverentsi ettekanded Tartus 6.-7. aprillil 2000. Toim T. Tender. Eesti Raamatu Aasta Peakomitee, Tartu, 2001, 66-81; Brüggemann, K. Rahvusliku vaenlasekuju demontaažist ehk Carl Schirren kui Eesti iseseisvuse rajaja? - Tuna, 2002, 3, 93-98; Undusk, J. Eesti ajaloo kotkaperspektiivist: minu vaidlus Brüggemanniga. - Tuna, 2002, 3, 99-116; Kivimäe, S., Kivimäe, J. Geschichtsschreibung und Geschichtsforschung in Estland 1988-2001. - Klio ohne Fesseln: Historiographie im östlichen Europa nach dem Zusammenbruch des Kommunismus. Hrsg. v. A. Ivanišević, A. Kappeler, W. Lukan, A. Suppan. (Osthefte, 16.) Peter Lang, Wien etc., 2003, 159-170; Brüggemann, K. „Wir brauchen viele Geschichten“: Estland und seine Geschichte auf dem Weg nach Europa? - GegenErinnerung: Geschichte als politisches Argument im Transformationsprozeß Ost-, Ostmittel- und Südosteuropas. Hrsg. v. H. Altrichter. (Schriften des Historischen Kollegs, 61.) Oldenbourg, München, 2006, 27-50; Karjahärm, T. Oleviku minevikud: Ajaloolase käsiraamat. 2., ümbertöötatud tr. Argo, Tallinn, 2010; Kivimäe, J. Märkmeid teiselt kaldalt: Ajaloo talumatu kergus. - Tuna bibliograafia 1998_ 2010. Koost B. Kibal. Rahvusarhiiv, Tallinn, 2011, 5-11; Tamm, M. Monumentaalne ajalugu: Esseid Eesti ajalookultuurist. (Loomingu Raamatukogu, 28-30.) Kultuurileht, Tallinn, 2012; Brüggemann, K., Laur, M. Kulturtransfer und nationale Wissenschaft: Einige Thesen aus estnischer Perspektive. - Jahrbücher für Geschichte Osteuropas, 2013, 61, 3, 366-372; Rosenberg, T. Eesti ajalugu - kas rahvusajalugu, maa-ajalugu või regionaalajalugu? - Rahvusvahelised rahvusteadused: Artiklikogumik rahvusülikooli 95. juubeliks. Toim T. Hennoste. Tartu Ülikooli Kirjastus, Tartu, 2014, 19-39.

${ }^{5}$ Vt nt Konsa, M. et al. Missugune sa oled, Eesti arheoloogia? - Eesti Arheoloogia Ajakiri, 2003, 7, 1, 72-94; Archaeological research in Estonia, 1865-2005. Ed. by V. Lang, M. Laneman. (Estonian Archaeology, 1.) University of Tartu, Tartu, 2006; Kuhu lähed, Eesti kunstiteadus? Pühendatud Armin Tuulse 100. sünniaastapäevale. Koost K. Kodres. Kunstiteaduslikke Uurimusi, 2008, 17, 3; Tammela, H., Liivik, O. Kas Eesti lähiajaloos on endiselt „valgeid laike“? - Tuna, 2010, 4, 129135; A socialist realist history? Writing art history in the post-war decades. Ed. by K. Kodres, K. Jõekalda, M. Marek. Böhlau, Köln, Weimar, Wien, 2019. 
Käesolevat Acta Historica Tallinnensia teemanumbrit võibki käsitleda seniste harali historiograafiaarutelude jätkuna ja see on kantud soovist pakkuda kriitilist vahekokkuvõtet Eesti ajalooteaduse arengust käimasoleval sajandil. Mõistagi ei pretendeeri ajakirjanumber ammendavale käsitlusele, sest põhjalikumaks alusuuringuks puudusid nii vahendid kui ka avaldamismaht, kummati peaks siit välja joonistuma linnulennuline ülevaade olulisematest töödest ja trendidest peamiste ajalooperioodide lõikes, seda täiendavad mõned temaatilised sissevaated. Kaastööd kajastavad Acta Historica Tallinnensia üldist haaret, s.t keskendutud on ajaperioodile keskajast tänapäevani ning ajalooteadusele kitsamas mõttes (seega on vaatluse alt välja jäänud arheoloogia, kunstiajalugu, etnoloogia jt ajalooteadusele lähedased distsipliinid). Vaatlusalused ajalooperioodid on eristatud suure üldistusastmega: keskaeg (1200-1500), varauusaeg (1500-1800), uusaeg (1800-1900) ja lähiaeg (1900-2000), nii et selle taga ei tule näha Eesti ajaloo uut periodiseerimiskatset, vaid väga tinglikku viisi uurimisainest käepäraselt liigendada. Kuna teemanumbri põhiartiklid keskenduvad peamiselt ideedele, siis siinse sissejuhatuse ülesanne on tagasihoidlikum - pakkuda taustainformatsiooni inimestest ja institutsioonidest, mis seisavad nende ideede taga. Vaatenurk on valitud teadlikult pigem kvantitatiivne, s.t näen oma peamise ülesandena varustada lugejaid olulisemate arvnäitajatega, mis Eesti ajalooteadust uuel sajandil on iseloomustanud. Konkreetsemalt keskendun viiele teemale: esiteks püüan kaardistada Eesti ajalooteadust uurijate vaates, teiseks institutsioonide vaates ning kolmandaks rahastuse vaates; seejärel peatun ajaloolaste publitseerimispraktikatel ja lõpetuseks katsun pakkuda mõne üldistava tähelepaneku Eesti ajalooteaduse arengujoontest uuel sajandil.

\section{KES UURIVAD EESTIS AJALUGU?}

Kui palju on Eestis ajaloolasi? Sellele esmapilgul lihtsale küsimusele ei ole tegelikult kuigi lihtne vastata. Seda vähemalt kahel põhjusel. Esiteks, kuidas üldse defineerida ajaloolast? Kas ajaloolased on kõik need, kes on omandanud sel alal kõrghariduse? Või ainult need, kes töötavad oma kutsetööl? Ja kuidas seda kutsetööd piiritleda - kas ainult ülikoolide ja teadusasutuste akadeemiliste ametikohtadega või mahuvad siia alla ka töökohad muuseumides ja arhiivides, ehk samuti koolides? Ja kas arvesse lähevad ainult Eestis töötavad ajaloolased või ka need, kes on rakendust leidnud välismaal? Asja ei hõlbusta ajaloo kui distsipliini enda piiritlemine, seda eriti viimastel kümnenditel, kui valdkonnaülene koostöö on üha tihedam. Seega tundub kõige paslikum lähtuda ajaloolase n-ö ad hoc defineerimisest, kord kitsamalt, kord avaramalt, vastavalt vajadusele ja vaatenurgale. Teiseks tuleb aga tõdeda, et teadaolevalt ei korja Eestis ükski asutus andmeid kutseliste ajaloolaste arvukuse kohta. ${ }^{6}$ Seega saab opereerida vaid oletuslike arvudega. Üks viis oleks

\footnotetext{
${ }^{6}$ Kõige usaldusväärsem andmebaas on tõenäoliselt ETIS (Eesti Teadusinfosüsteem), kuhu iga teadlane ise oma andmed üles annab, ent sealt ajaloolaste eraldi väljaotsimine on väga keeruline ja aeganõudev töö; lisaks on Eestis kindlasti päris palju ajaloolasi, kellel ETIS-es konto puudub. Statistikaameti kinnitusel nemad ajaloolaste kohta süsteemselt andmeid ei korja.
} 
vaadata ajaloolaste peamise kutseühingu liikmete arvu. 2020. aasta seisuga on Eesti Akadeemilisel Ajalooseltsil ligemale sada liiget, ${ }^{7}$ ent seltsi ei kuulu kaugeltki kõik Eesti ajaloolased. Võrdluseks võib tuua, et Eesti Arhivaaride Ühingul on praegu 120 liiget (sh ka au- ja välisliikmed) ning Eesti Muuseumiühingul ligikaudu 300 liiget. $^{8}$ Rääkimata Eesti Ajaloo- ja Ühiskonnaõpetajate Seltsist, millel on 391 liiget. ${ }^{9}$

Teine, ilmselt täpsem viis oleks vaadata, kui palju ajaloolaste töökohti on ülikoolides, uurimiskeskustes ja mäluasutustes. 2020. aasta 1. septembri seisuga töötab Tartu Ülikooli ajaloo ja arheoloogia instituudis poolsada akadeemilist töötajat, Tallinna Ülikooli ajaloo, arheoloogia ja kunstiajaloo keskuses ning ajaloo akadeemilisel suunal on praegu palgal 26 akadeemilist töötajat. Kui vaadata suuremaid uurimisja mäluasutusi, siis Eesti Mälu Instituudis on tööl u 10 inimest, kelle tööd võiks siduda ajalooalase uurimistööga, Eesti Ajaloomuuseumis on neid u 20, Tallinna Linnaarhiivis u 10 ja Eesti Sõjamuuseumis - Kindral Laidoneri Muuseumis u 5. Eesti Rahvusarhiivis ja selle allasutustes töötab ligemale 80 inimest, keda võiks seostada ajaloolase kutsetööga avaras mõistes. Eesti Muinsuskaitseametis on neid pea poolsada. Kui siia lisada veel mõned suuremad raamatukogud ja väiksemad ajaloomuuseumid, kus tavaliselt teeb oma kutsetööd vaid mõni üksik ajaloolane, samuti pensioneerunud uurijad, siis võiks pakkuda, et praegu tegutseb Eestis kuni 400 ajaloolast, s.t avaralt mõistetud ajalookutsetööd tegevat inimest. Neid ajaloolasi, kelle palgaline põhitegevus on teadustöö, ei ole aga ilmselt rohkem kui sadakond. Tõsi, see nimekiri saaks pikem, kui siia lisada ajalookraadiõppe üliõpilased (magistrandid ja doktorandid), ent nendest kohe edaspidi veidi lähemalt.

Kui lihtsustavalt eeldada, et ajaloo uurimise horisonti kujundavad kõige enam ülikoolide ajalooprofessorid, siis neid leiab k.a 1. septembri seisuga Eestist kokku 22 , kui lähtuda väga avarast ajaloomääratlusest, s.t kaasata erinevaid ajaloolisi distsipliine (professoreid on Eestis praegu üldse 567). Üksteist tegevprofessorit töötab Tartu Ülikoolis, neist kaheksa ajaloo ja arheoloogia instituudis (Aivar Kriiska - laboratoorse arheoloogia professor, Valter Lang - arheoloogia professor, Mati Laur uusaja professor, Juhan Maiste - kunstiajaloo professor, Eero Medijainen - uusima aja professor, Olaf Mertelsmann - Ida-Euroopa ajaloo professor, Anti Selart - keskaja professor, Tõnu-Andrus Tannberg - Eesti ajaloo professor), üks filosoofia ja semiootika instituudis (Pärtel Piirimäe - mõtteloo professor), üks õigusteaduskonnas (Marju Luts-Sootak - õiguse ajaloo professor) ja üks usuteaduskonnas (Riho Altnurme - kirikuloo professor). Tallinna Ülikoolis on praegu ametis neli ajalooprofessorit (Karsten Brüggemann - Eesti ja üldajaloo professor, Kersti Markus kunstiajaloo professor, Ulrike Plath - baltisaksa uuringute ja keskkonnaajaloo professor, Marek Tamm - kultuuriajaloo professor); viiendana võib siia lisada tiitli poolest poliitikafilosoofia professori, ent väljaõppelt ja uurijaprofiililt mõtteajaloo-

\footnotetext{
7 Akadeemilise Ajalooseltsi kodulehel (http://ajalooselts.blogspot.com/) andmed liikmete kohta puuduvad, ent siinne informatsioon on saadud AAS-i juhatuse liikme Anti Selarti käest (11.08.2020).

8 Eesti Arhivaaride Ühing - liikmed, https://eay.ee/liikmed/; Eesti Muuseumiühingu liikmete arv pärineb entsüklopeedia Estonica veebilehelt: http://www.estonica.org/et/Haridus_ja_teadus/Kultuuri$\operatorname{varad} /$ Arhiivid,_raamatukogud_ja_muuseumid_t\%C3\%A4nases_Eestis/ (11.08.2020).

$9 \mathrm{Vt} \mathrm{https://www.eays.edu.ee/liikmed/} \mathrm{(11.08.2020).}$
} 
lase Liisi Keeduse. Eesti Kunstiakadeemias on ametis neli professorit, keda võib siduda ajalooliste uurimisteemadega (Linda Kaljundi, Krista Kodres, Andres Kurg ja Virve Sarapik), ning Eesti Muusika- ja Teatriakadeemias kaks (Kristel Pappel ja Toomas Siitan). Kui kiirelt üldistada, siis Eesti ajalooteaduse üks tunnusjooni 21. sajandi esimestel kümnenditel ongi olnud professorkonna kiire kasv, sh professuuride avamine üha uutes uurimisvaldkondades.

Professorid ei ole aga kindlasti ainsad, kes Eesti ajalooteaduse ilmet kujundavad; selle kinnituseks võib näiteks vaadata, kes ajaloolastest on sel sajandil pälvinud riigi teaduspreemia humanitaarteaduste valdkonnas: Mati Laur (2004), Magnus Ilmjärv (2005), Anu Mänd (2006), Linnart Mäll (2008), Arvo Tering (2009), Valter Lang (2011), Mart Kalm (2012), Andres Tvauri (2013), Andres Kasekamp (2014), Krista Kodres (2015), Tõnu Tannberg (2016), Heiki Valk (2017), Marika Mägi (2020). ${ }^{10}$ Professoreid on selles nimekirjas viis ehk alla poole. Kuid kindlasti on rõhutamisvärne, et humanitaarteaduste valdkonna kõige hinnatuma riikliku tunnustuse on viimasel kahekümnel aastal pälvinud kolmteist ajaloolast (sh arheoloogid ja kunstiajaloolased), see tähendab, et rohkem kui pooltel aastatel on preemia läinud ajaloovaldkonda (viimasel kümnendil seitse aastat järjest).

Pakutud ligikaudsed andmed ajaloolaste hulgast käivad aga vaid praeguse olukorra kohta, mis meie teadusrahastuse heitlikkust ja ennustamatust arvestades võib muutuda võrdlemisi kiiresti, vähemalt ülikoolides. Paraku on väga raske, kui mitte võimatu, leida andmeid ajaloolaste arvukuse dünaamika kohta viimasel kahel kümnendil. Seega on keeruline hinnata, kas saab rääkida märkimisväärsest juurdekasvust või pigem mitte. Tõenäoliselt on areng olnud siiski märgatav, arvestades õppejõudude ringi laienemist ja uusi ametikohti mäluasutustes. Sellega seoses kerkib üles küsimus põlvkonnavahetusest uue sajandi Eesti ajalooteaduses. ${ }^{11}$ Seni on see läbi valgustamata teema, kuigi on loogiline eeldada, et kahekümne aasta jooksul on põlvkondlikud nihked paratamatud. Kui vaadata ühe näitajana praeguse professorkonna keskmist vanust, siis on see 55; alla 50-aastaseid ajalooprofessoreid on ainult seitse. Enne 2000. aastat on ajaloovaldkonna 22 professorist ametisse valitud siiski vaid kolm.

Akadeemilises maailmas märgib põlvkonnavahetust tihti nn Festschrift, uurimuslik koguteos või teadusajakirja teemanumber, mis on pühendatud soliidsesse ikka jõudnud kolleegile ja õpetajale. Ajaloolastele on viimasel paaril kümnendil Festschrift'e pühendatud kaheksa, need on pälvinud 1998 Vello Helk (1923-2014), 2000 Aleksander Loit (snd 1925), 2001 Sulev Vahtre (1926-2007), 2005 Helmut Piirimäe (1930-2017), 2009 Enn Tarvel (snd 1932), 2010 Raimo Pullat (snd 1935), 2016 Aadu Must (snd 1950) ja 2017 Jüri Kivimäe (snd 1947). ${ }^{12}$ Arheoloogidest on

${ }^{10} \mathrm{https}: / / w w w . h m . e e / e t / t e a d u s p r e e m i a d ~(11.08 .2020)$; olgu lisatud, et mitu ajaloolast on sel sajandil pälvinud ka riigi teaduspreemia pikaajalise tulemusliku teadus- ja arendustöö eest: Sulev Vahtre (2004), Ea Jansen (2005), Ants Viires (2007) ja Enn Tarvel (2014).

${ }^{11}$ Vt võrdlevalt: Pistohlkors, G. von. Põlvkonnad baltisaksa ajalookirjutuses aastail 1919-2009. Tlk J. Undusk. - Tuna, 2010, 2, 34-47.

${ }^{12}$ Festschrift für Vello Helk zum 75. Geburtstag: Beiträge zur Verwaltungs-, Kirchen- und Bildungsgeschichte des Ostseeraumes. Hrsg. v. E. Küng, H. Tamman. Eesti Ajalooarhiiv, Tartu, 1998; Time of change in the Baltic countries: Essays in honour of Aleksander Loit. Ed. by A. M. Kõll. University 
pühendusteose pälvinud seitse: 2000 Lembit Jaanits (1925-2015), 2003 Jüri Selirand (1928-2017), 2004 Vilma Trummal (snd 1924), 2006 Silvia Laul (1931-2013), 2014 Evald Tõnisson (1928-2001), 2014 Mare Aun (snd 1939) ja 2018 Jaan Tamm (snd 1948). ${ }^{13}$ Kunstiajaloolastest on pühendusteoseid pälvinud kuus, mõni küll postuumselt või korduvalt: 1995, 2009 ja 2010 Villem Raam (1910-1996), 2008 Mai Lumiste (1931-1985), 2008 Armin Tuulse (1907-1977), 1999 ja 2008 Sten Karling (1906-1987), 2011 Helmi Üprus (1911-1978) ning 2017 Kaur Alttoa (snd 1947). ${ }^{14}$ Kui vaadata seda nimekirja põlvkondlikust vaatenurgast, siis joonistub üsna selgelt välja kaks kohorti: esiteks ja põhiosas veel enne Teist maailmasõda sündinud teadlased, kelle innustada ja koolitada oli sõjajärgne ajaloolaste põlvkond, ja teiseks seesama sõjajärgne generatsioon, kes kujundas suuresti praegu aktiivses loomeeas Eesti ajaloolaste põlve. Ent lisaks põlvkonnavahetuse markeerimisele täidavad Festschrift'id kindlasti olulist rolli distsipliinimälu kultiveerimisel ja valdkonna eneseteadlikkuse tõstmisel.

of Stockholm, Department of Baltic Studies, Stockholm, 2000; Muinasaja loojangust omariikluse läveni: Pühendusteos Sulev Vahtre 75. sünnipäevaks. Koost A. Andresen. Kleio, Tartu, 2001; Die baltischen Länder und der Norden: Festschrift für Helmut Piirimäe zum 75. Geburtstag. Hrsg. v. M. Laur, E. Küng, S. Ö. Ohlsson. Akadeemiline Ajalooselts, Tartu, 2005; Sõnasse püütud minevik: In honorem Enn Tarvel. Koost P. Raudkivi, M. Seppel. Argo, Tallinn, 2009; Modus vivendi III: Studia historica in honorem Raimo Pullat LXXV. Toim T. Liibek. (Vana Tallinn, 21 (25).) Estopol, Tallinn, 2010; Aadu Must - 65. Ajalooline Ajakiri, 2016, 2; Jüri Kivimäele 70. sünnipäevaks. Koost J. Kreem. (Vana Tallinn, 28 (32).) Tallinna Linnaarhiiv, Tallinn, 2017.

${ }^{13}$ De temporibus antiquissimis ad honorem Lembit Jaanits. Koost ja toim V. Lang, A. Kriiska. Teaduste Akadeemia Kirjastus, Tallinn, 2000; Arheoloogiga Läänemeremaades: Uurimusi Jüri Seliranna auks. Koost ja toim V. Lang, Ü. Tamla. Teaduste Akadeemia Kirjastus, Tallinn, Tartu, 2003; Linnusest ja linnast: Uurimusi Vilma Trummali auks. Koost ja toim A. Haak, E. Russow, A. Tvauri. Teaduste Akadeemia Kirjastus, Tallinn, Tartu, 2004; Etnos ja kultuur: Uurimusi Silvia Laulu auks. Koost ja toim H. Valk. Tartu Ülikooli arheoloogia õppetool, Tartu, Tallinn, 2006; Strongholds and power centres east of the Baltic Sea in the 11th-13th centuries: A collection of articles in memory of Evald Tõnisson Ed. by H. Valk. University of Tartu, Institute of History and Archaeology, Tartu, 2014; Ajast ja ruumist: Uurimusi Mare Auna auks. Koost ja toim Ü. Tamla, V. Lang. Tallinna Ülikooli Ajaloo Instituut, Tartu Ülikool, Tallinn, Tartu, 2014; Pühakud, piiskopid, linnad ja linnused: Ajarännakuid kesk- ja varauusaega: Uurimusi Jaan Tamme auks. Koost ja toim E. Russow, V. Lang. Tallinna Ülikooli Ajaloo Instituut, Tartu Ülikool, Tallinn, Tartu, 2018.

${ }^{14}$ Ars Estoniae medii aevi grates Villem Raam viro doctissimo et expertissimo. Koost K. Alttoa. Eesti Muinsuskaitse Selts, Tallinn, 1995. Muinsuskaitse ja restaureerimise ajaloost: Pühendatud Villem Raami 100. sünniaastapäevale. Koost A. Randla. (Kunstiteaduslikke uurimusi, 3-4 (18).) Kunstiteadlaste ja Kuraatorite Ühing, Tallinn, 2009; Villem Raam 100. Ed. by A. Randla. Baltic Journal of Art History, 2010, 2; Uurides kesk- ja uusaja kunsti ENSV-s: Mai Lumiste 80. Toim A. Randla. (Kunstiteaduslikke uurimusi, 22, 3-4) Kunstiteadlaste ja Kuraatorite Ühing, Tallinn, 2013; Kuhu lähed, Eesti kunstiteadus? Pühendatud Armin Tuulse 100. sünniaastapäevale. Koost K. Kodres. (Kunstiteaduslikke uurimusi, 17, 3) Kunstiteadlaste ja Kuraatorite Ühing, Tallinn, 2008; Sten Karling and Baltic art history. Ed. by K. Kodres, J. Maiste, V. Vabar. Teaduste Akadeemia Kirjastus, Tallinn, 1999; Art and the church: Religious art and architecture in the Baltic region in the 13th18th centuries: Conference dedicated to the centenary of Sten I. Karling in Tallinn, Sept. 6-9, 2006. Ed. by K. Kodres, M. Kurisoo. Eesti Kunstiakadeemia, Tallinn, 2008; Helmi Üprus 100. Ed. by J. Maiste. Baltic Journal of Art History, 2011, 3; Järelevastamine: Kaur Alttoale. Toim A. Randla. Eesti Kunstiakadeemia, Tallinn, 2017; Kaur Alttoa 70. Baltic Journal of Art History, 2017, 13. 
Kui kutseliste ajaloolaste juurdekasvu statistika, nagu tuleb tõdeda, on puudulik, siis palju parem on seis järelkasvu osas, s.t andmed üliõpilaste arvu kohta. Pole ilmselt liialdus öelda, et 2000. aastate esimesed kümnendid on olnud ajalooõppe kuldsed aastad, sest nii palju kõrgharidusega ajaloolasi ei ole Eestis ette valmistatud kunagi varem ja pole kindel, kas seda suudetakse ületada tulevikuski. Vaadeldava perioodi tähtis areng on ajalooõppe laienemine Tartust Tallinnasse. Kuigi ajaloo õppetool (juhataja Mati Graf) loodi Tallinna Pedagoogilisse Instituuti juba 1990. aastal, pakuti esialgu ainult üksikuid loenguid teiste erialade üliõpilastele. Kõrvalerialana avati ajalooõpe uue nimega Tallinna Pedagoogikaülikoolis 1992. aastal, ent peaerialana alles 1999. aastal. Ajalugu õpetati ka 1989. aastal Tallinnas asutatud Eesti Humanitaarinstituudis, mis alates 2003. aastast hakkas pakkuma koos pedagoogikaülikooliga ühist ajalooõpet (nii bakalaureuse kui ka magistri tasemel), kus kandev roll oli Ajaloo Instituudi teadlastel. Ajaloo doktorikavale toimus pedagoogikaülikoolis esimest korda vastuvõtt 2003/2004. õppeaastal, ent juba mõned aastad varem oli loodud kultuuriajaloo doktorikava (koos magistrikavaga), mille raames kaitsti esimesed doktoritööd 2000. aastal. Alates 2015. aasta struktuurireformist on ajalooõpe kõigis kolmes õppeastmes Tallinna Ülikooli humanitaarteaduste instituudi ajaloo akadeemilise suuna hallata. ${ }^{15}$

Tartu Ülikoolis, kus ajalooõpe ulatub ülikooli algaegadesse, liigendati 1990. aastate esimese poole ümberkorralduste tulemusena ajaloo osakond seitsme õppetooli vahel, millest igaüks võimaldas tudengitel spetsialiseeruda kitsamale erialale: arheoloogia, arhiivindus, Eesti ajalugu, etnoloogia, kunstiajalugu, lähiajalugu ja üldajalugu. 2007. aasta struktuurireformiga moodustati ajaloo osakonna baasil ajaloo ja arheoloogia instituut, mis alates 2013. aastast koosneb kuuest osakonnast: arheoloogia, arhiivinduse, Eesti ajaloo, kunstiajaloo, uusima aja ja üldajaloo osakond. Iga osakond pakub oma valdkonnas õpet kõigis kolmes õppeastmes (lisaks saab magistriastmes spetsialiseeruda ajaloo ja ühiskonnaõpetuse õpetajaks, nagu ka Tallinna Ülikoolis). ${ }^{16}$

Kui heita pilt üliõpilaste statistikale, siis bakalaureuseõppes joonistub üsna selgelt välja rajajoon kahe viimase kümnendi vahel, mis on osaliselt seotud 2013/2014. õppeaasta sügisel lõpule jõudnud kõrgharidusreformiga, mis ühtlustas kõigi sisseastujate jaoks tasuta kõrghariduse omandamise võimalused ehk teisisõnu kaotas tasulise õppe. Võrreldes eelmise kümnendiga on ajalootudengite üldarv vähenenud reformijärgselt umbes kolmandiku võrra (joonis 1), samas tuleb täheldada, et lõpetanute seas on vähenemine olnud mõõdukam (joonis 2). Ajalootudengite arvu kahanemine on kindlasti seotud ka demograafilise arengu ja välisülikoolide tõmbejõuga, mistõttu Eesti ülikoolidesse ongi viimasel kümnendil jõudnud vähem tudengeid kui varem. Samuti näitavad arvandmed, et lõviosa ajaloolaste järelkasvust tuleb endiselt Tartu Ülikoolist, kuigi reformijärgselt on vahe Tallinnaga kahanenud.

${ }^{15}$ Vt Oja, M. Development of the history teacher curriculum in Tallinn University: Trends and challenges. - The International Journal of Research on History Didactics, History Education and History Culture, 2017, 38, 33-50.

${ }^{16} \mathrm{Vthttps}$ //www.flaj.ut.ee/et/ajalugu (10.08.2020). 


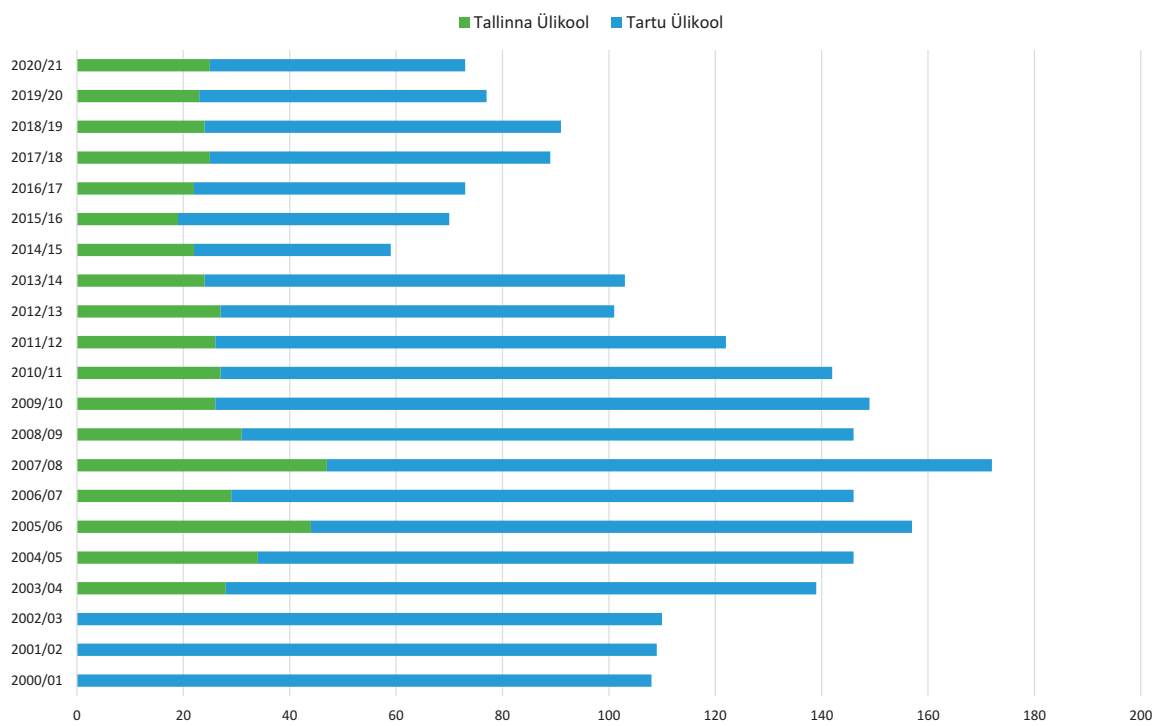

Joonis 1. Ajaloo erialal bakalaureuseõppesse vastuvõetute arv Tallinna ja Tartu Ülikoolis aastatel 2000-2020..$^{17}$

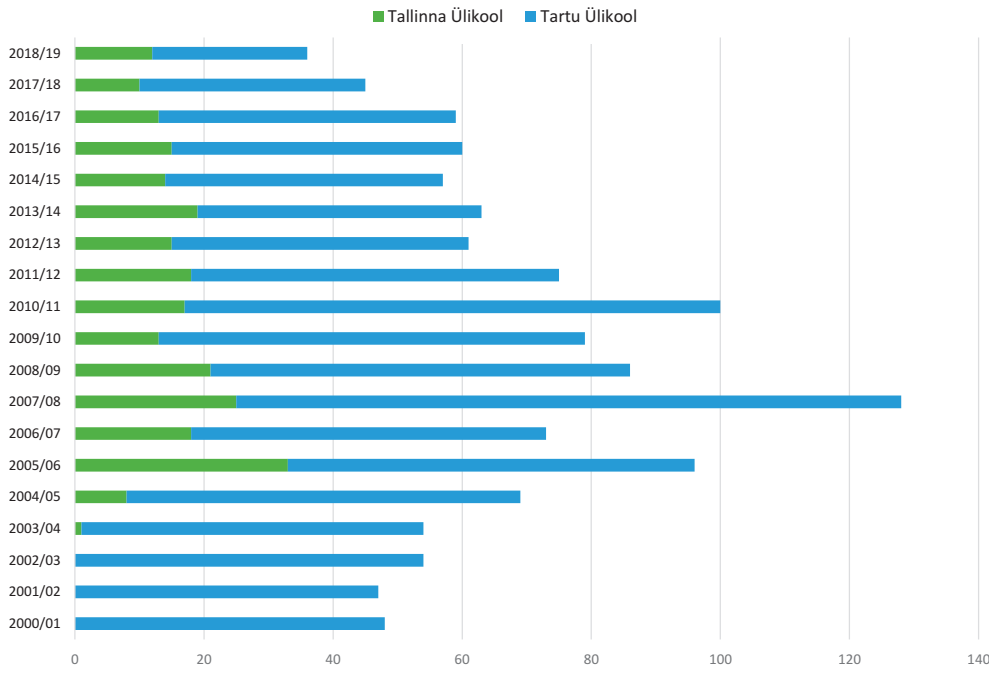

Joonis 2. Ajaloo erialal bakalaureuseõppe lõpetanute arv Tallinna ja Tartu Ülikoolis aastatel 2000-2019. ${ }^{18}$

${ }^{17}$ Põhiosas on andmed võetud Haridus- ja Teadusministeeriumi andmebaasist Haridussilm (https://www.haridussilm.ee/); aastate 2000-2005 andmeid, mis Haridussilmas puuduvad, on täiendatud TLÜ ja TÜ ÕIS-i põhjal. TLÜ esimese kolme aasta andmed puuduvad. Viimase aasta andmed pärinevad SAIS-ist (https://sais.ee/). Silmas tuleb pidada, et 2002/2003. õppeaastal mindi Eestis üle 3+2 (nn Bologna) kõrgharidusmudelile, mis tähendab, et varem sisse astunud tudengid õppisid 4-aastases diplomiõppes. Joonisel ei ole seda erisust välja toodud. Kõik andmed on kogutud seisuga 10.08.2020.

${ }^{18}$ Andmed on põhiosas võetud andmebaasist Haridussilm; aastate 2000-2005 andmeid on täiendatud TLÜ ja TÜ ÕIS-i põhjal. TLÜ esimese kolme aasta kohta andmed puuduvad. Silmas tuleb pidada, et enne 2002/2003. õppeaastat immatrikuleeritud tudengid õppisid 4-aastases diplomiõppes, ent joonisel ei ole seda erisust välja toodud. Kõik andmed on kogutud seisuga 10.08.2020. 
Magistriõppes on pilt stabiilsem, vastuvõtt on viimase viieteistkümne aasta jooksul püsinud üldiselt 30-35 tudengi piires, lõpetajate hulk on olnud keskmiselt kümne inimese võrra väiksem (joonised 3 ja 4). Ka magistriõppes on Tartu Ülikoolis olnud tudengeid rohkem.

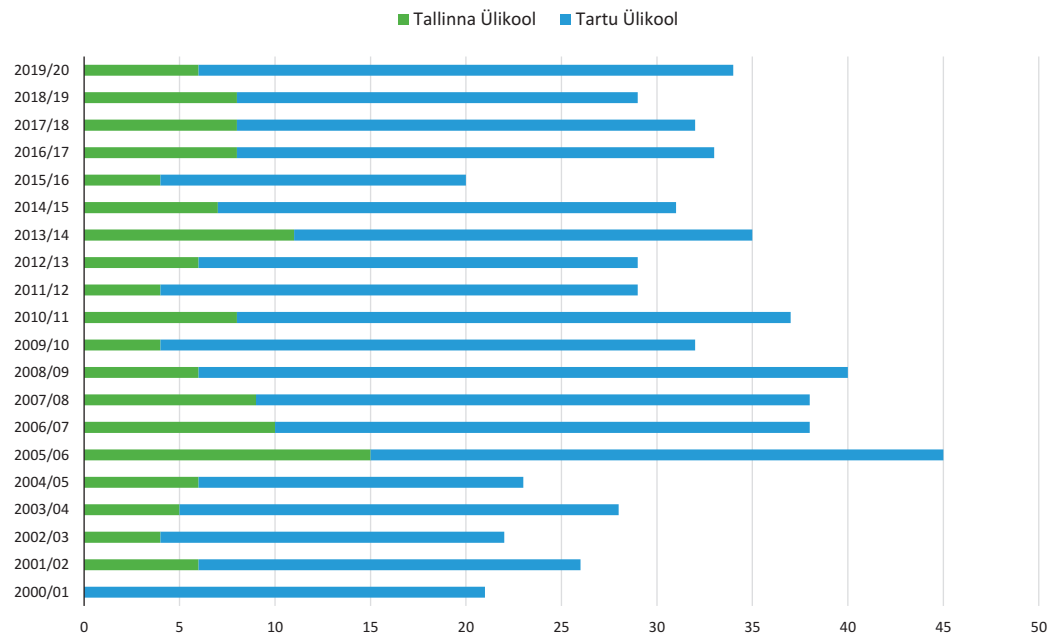

Joonis 3. Ajaloo erialal magistriõppesse vastuvõetute arv Tallinna ja Tartu Ülikoolis aastatel 2000 $2020 .{ }^{19}$

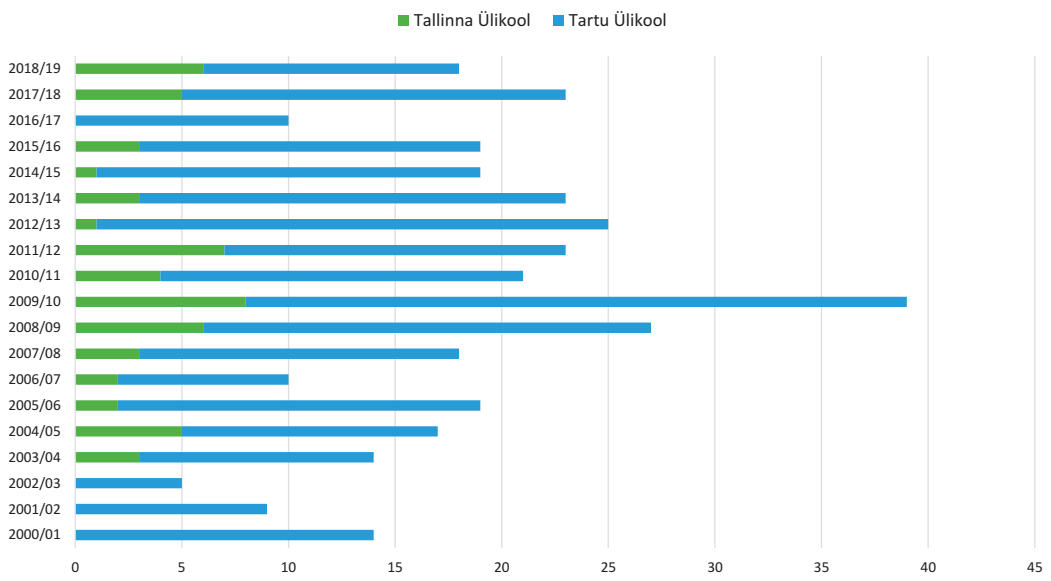

Joonis 4. Ajaloo erialal magistriõppe lõpetanute arv Tallinna ja Tartu Ülikoolis aastatel 2000-2019. ${ }^{20}$

${ }^{19}$ Andmed on põhiosas võetud andmebaasist Haridussilm; aastate 2000-2005 andmeid, mis Haridussilmas puuduvad, on täiendatud TLÜ ja TÜ ÕIS-i põhjal. Viimase aasta andmed pärinevad SAIS-ist. TLÜ magistrivastuvõtt algas 2001. Silmas tuleb pidada, et enne 01.06.2002 oli Eestis võimalik magistrikraadi teaduskraadina kaitsta Eesti Hariduse Infosüsteemi kantud magistriõppe ehk nn 4+2 magistriõppekava läbimise järel. Vastuvõtt nn teadusmagistri õppekavadele lõpetati 01.09.2005. Joonisel ei ole seda erisust välja toodud. Kõik andmed on kogutud seisuga 10.08.2020.

${ }^{20}$ Andmed on põhiosas võetud andmebaasist Haridussilm; aastate 2000-2005 andmeid on täiendatud TLÜ ja TÜ ÕIS-i põhjal. TLÜ ajaloo magistriõppe esimesed lõpetajad on 2004. aastast. Silmas 


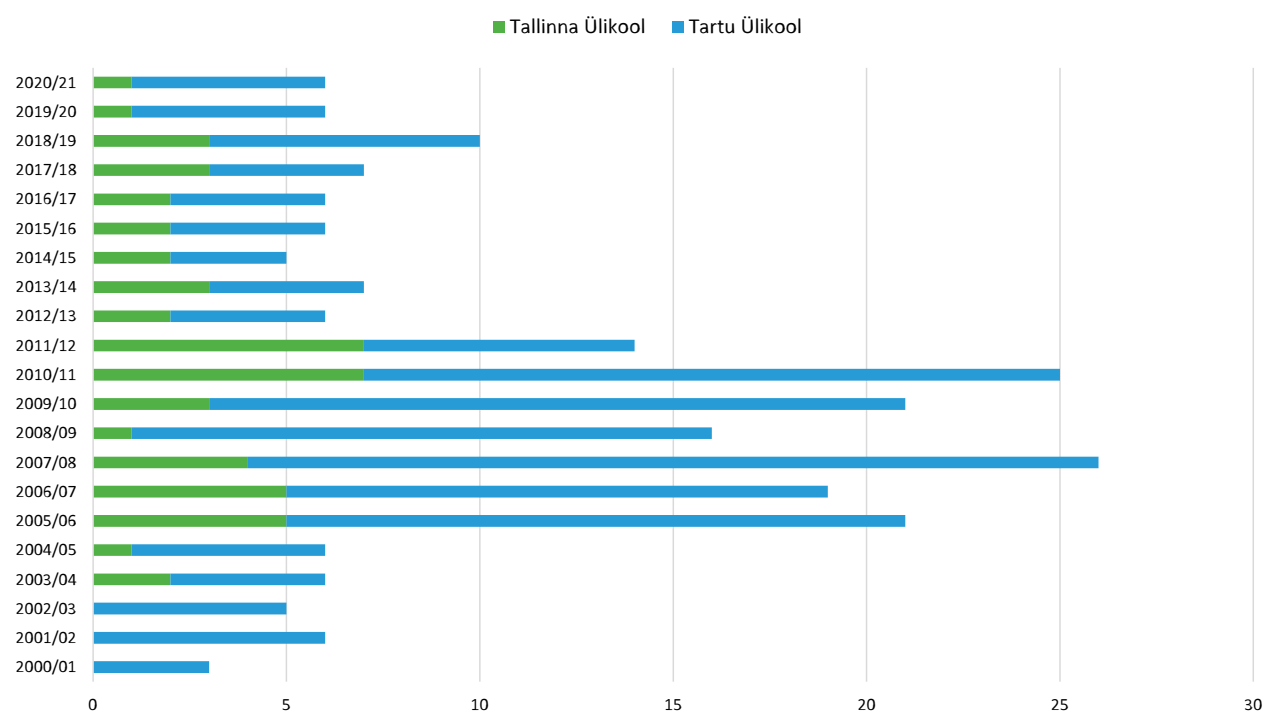

Joonis 5. Ajaloo erialal doktoriõppesse vastuvõetute arv Tallinna ja Tartu Ülikoolis aastatel 2000-2020. ${ }^{21}$

Doktoriõppes on eelmisel kümnendivahetusel toimunud samasugune katkestus kui bakalaureuseõppes - alates 2012/2013. õppeaastast on ajaloodoktorantide hulk kahanenud pea poole võrra, kusjuures viimased paar aastat kinnitavad pigem langustrendi jätkumist (joonis 5). Osaliselt on see seotud nn riigieelarveväliste doktorandikohtade kaotamisega kõrgharidusreformi käigus. Kindlasti ei saa lugeda kestlikuks praegust olukorda, kus aastas võetakse doktoriõppesse vaid kuus ajaloolast (viis Tartus ja üks Tallinnas), eriti kui arvestada, et õppekava hõlmab ka arheolooge ja kunstiajaloolasi. Veidi lohutust pakub vaid teadmine, et üha enam ajaloolasi läbib doktoriõppe välismaal, aga siingi ei saa selgest tõusutrendist rääkida (joonis 6). Roosiline ei ole pilt ka vastsete doktorite osas, kuigi siin on veel vara langustrendist rääkida, arvestades, et keskmiselt kulub doktorantuuri läbimiseks mitu aastat rohkem kui nelja-aastane nominaalaeg (joonis 7).

Kuna kogutud statistika seda lubab, siis on huvitav heita pilk ka Tartu ja Tallinna Ülikooli ajaloodoktorantide ealisele ja soolisele jaotusele. Vanuselises vaates võib rääkida doktorantide mõningasest noorenemisest uuel sajandil (joonis 8). Kui veel selle kümnendi keskel oli enamik doktorante vanuses 35 ja enam, siis viimastel aastatel on kõige suuremaks rühmaks tõusnud doktorandid vanuses 30-34, samuti on veidi kasvanud vanuserühm 25-29, mis ülikooliõppe üldist loogikat $(3+2+4)$ arvestades peaks moodustama doktorantuuris enamuse. Vanuseline jaotus räägib üsna selget keelt sellest, et doktorantuuri ei astuta enamasti kohe pärast magistriõppe läbimist, vaid n-ö uuel ringil, pärast esimesi töökogemusi. Samuti viitab see tõsiasjale,

tuleb pidada, et vastuvõtt nn teadusmagistri õppekavadele lõpetati 01.09.2005, ent joonisel ei ole seda erisust välja toodud. Kõik andmed on kogutud seisuga 10.08.2020.

${ }^{21}$ Andmed on põhiosas võetud andmebaasist Haridussilm; aastate 2000-2005 andmeid on täiendatud TLÜ ja TÜ ÕIS-i põhjal. TLÜ ajaloo doktoriõppesse algas vastuvõtt 2003/2004. õppeaastal. Viimase aasta andmed pärinevad SAIS-ist. Kõik andmed on kogutud seisuga 10.08.2020. 


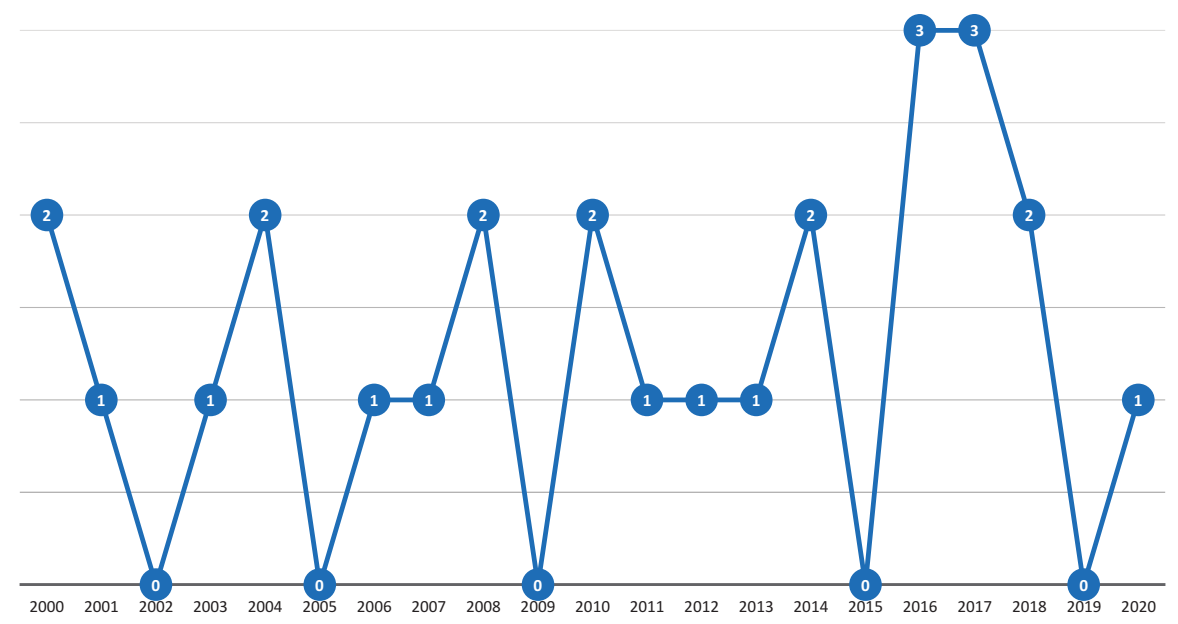

Joonis 6. Eestist pärit doktorantide välismaal kaitstud ajalooaineliste doktoritööde arv aastatel 2000 $2020 .^{22}$

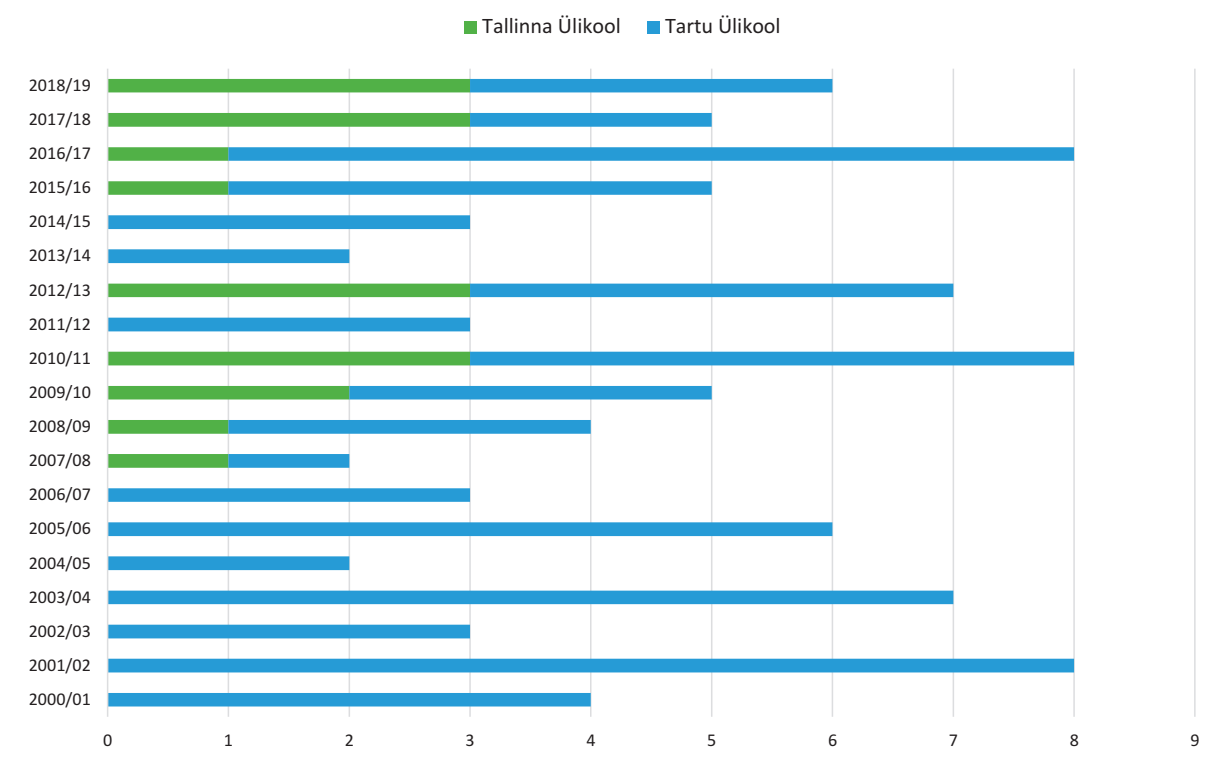

Joonis 7. Ajaloo erialal doktoriõppe lõpetanute arv Tallinna ja Tartu Ülikoolis aastatel 2000-2019.23

${ }^{22}$ Andmed on kogutud ise, kasutades veebimaterjale (ETIS, ülikoolide veebilehed) ja kolleegidelt saadud informatsiooni. Nimekirja on võetud ainult need doktorandid, kes on Eestis sündinud, s.t arvestatud pole väliseesti doktorante. Pole võimatu, et mõni väitekiri jäi kahe silma vahele. Nimekirjas on doktoritööd nii ajaloo, arheoloogia kui ka kunstiajaloo valdkonnast. Kaasatud on ka see doktoritöö, mis kaitsti 2020. aastal enne 1. septembrit.

${ }^{23}$ Andmed on põhiosas võetud andmebaasist Haridussilm; aastate 2000-2005 andmeid on täiendatud TÜ ÕIS-i põhjal. TLÜ ajaloo doktoriõppe esimene lõpetaja oli 2008. aastal; joonisel ei ole arvestatud varem TLÜ kultuuriajaloo doktorikava lõpetanuid (kokku 4). Kõik andmed on kogutud seisuga 10.08.2020. 


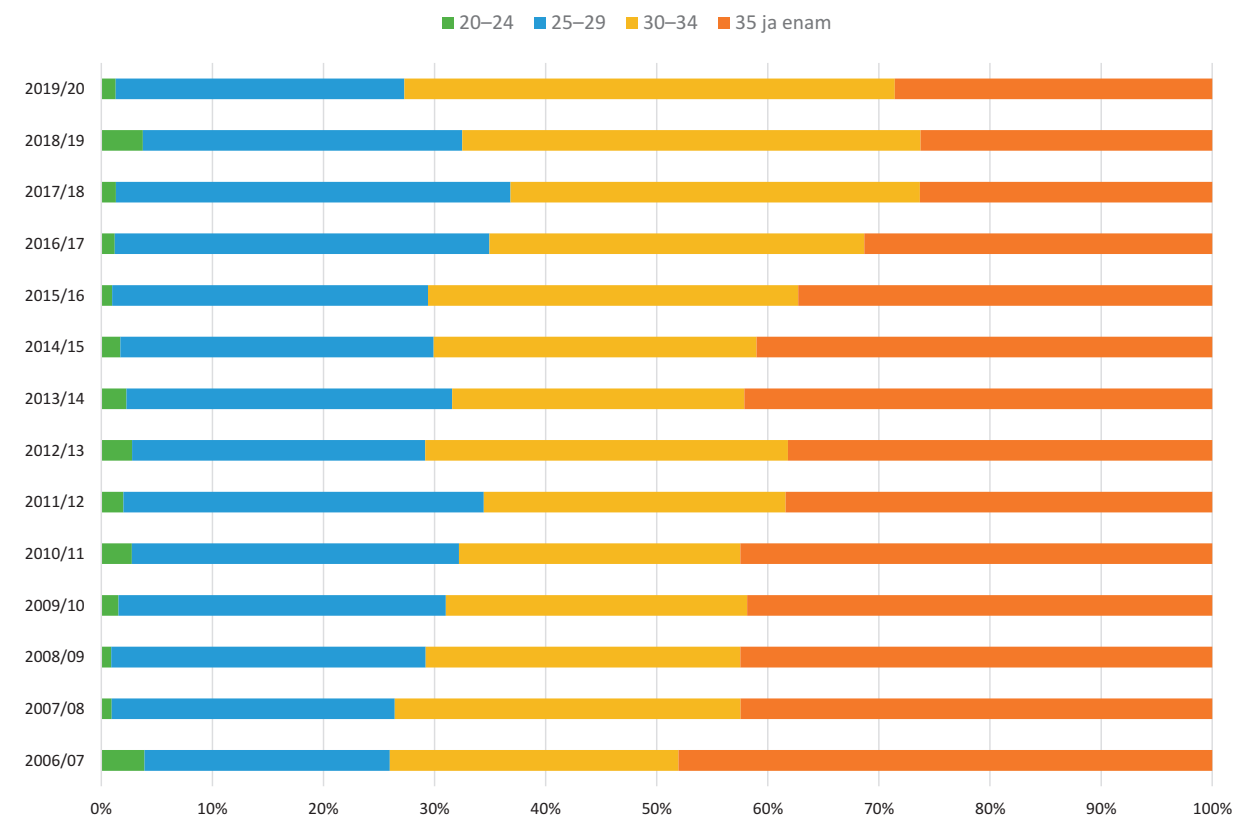

Joonis 8. Ajaloodoktorantide vanuseline jaotus Tallinna ja Tartu Ülikoolis aastatel 2006-2019. ${ }^{24}$

et nominaalajaga lõpetavad doktorandid on erandlikud. Ajaloodoktorantide sooline jaotus püsib aga üllatavalt stabiilne, viimasel viieteistkümnel aastal on see kõikunud ainult mõne protsendi võrra, s.o naisdoktorante on keskmiselt $52 \%$ (joonis 9). Kui vaadata ülikoolide professorkonda, siis seal on mehed endiselt selges ülekaalus (nt Tartu Ülikooli ajaloo ja arheoloogia instituudis pole sellel sajandil ametisse valitud ühtegi naisprofessorit).

Kui teha väike vahekokkuvõte, siis tooksin viimase kahe kümnendi Eesti ajalooteaduse isikkoosseisu iseloomustamiseks välja kolm märksõna. Esiteks võime puuduliku statistika kiuste eeldada, et uus sajand on märkinud ajaloolaskonna selget juurdekasvu. Sellest räägib nii kõrgharidusega ajaloolaste kiire kasv üldiselt kui ka kitsamalt doktorikraadiga ajaloolaste arvu mitmekordistumine. Kõige ilmekama näite pakub arheoloogiaeriala, kus aastatel 1990-2000 kaitsti vaid üks doktoritöö, samas kui järgmisel kümnendil kaitsti neid juba kakskümmend (9 Eestis ja 11 välismaal). Kui siia lisada muuseumivõrgu tihenemine, siis ei ole ilmselt liialdus väita, et mitte kunagi pole Eestis olnud kutselisi ajaloolasi nii palju kui praegu. Teine märksõna võiks olla rahvusvahelistumine - eales varem pole Eesti ajaloolased saanud nii ulatuslikult välismaal õppida ja nii intensiivselt rahvusvahelist koostööd teha kui selle sajandi esimestel kümnenditel. Esimesed uue põlve ajalooalased doktorikraadid kaitsti välismaal 1999. aastal (Anneli Randla Cambridge'is ja Kristjan Toomaspoeg Pariisis), sellest alates on ulgvel gradueerimine püsinud võrdlemisi stabiilne: kokku on viimasel kahel kümnendil kaitsnud välismaal oma doktorikraadi vähemalt 26 Eesti ajaloolast, arheoloogi või kunstiajaloolast (joonis 6); selget kasvu

\footnotetext{
${ }^{24}$ Andmed on võetud andmebaasist Haridussilm; aastate 2000-2005 andmed puuduvad.
} 


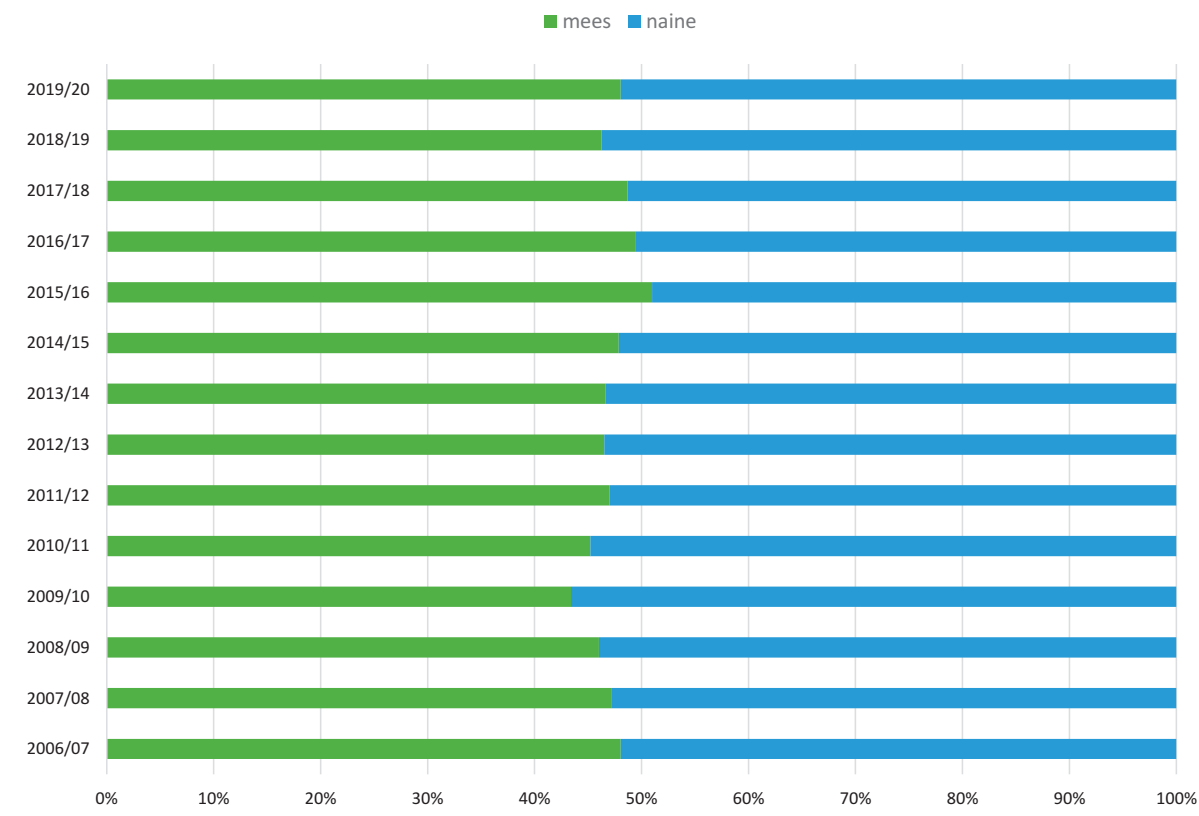

Joonis 9. Ajaloodoktorantide sooline jaotus Tallinna ja Tartu Ülikoolis aastatel 2006-2019.25

võib siiski eeldada bakalaureuse- ja magistriõppe tasandil, mille kohta statistikat paraku pole. Märkimisväärne on üha sagedasem välismaal sündinud ja hariduse saanud ajaloolaste eneseteostus Eesti ülikoolides, sh professoriametis. Seda positiivset üldpilti rikub aga viimaste aastate nähtus, mida võib nimetada teadustöötajate ametikohtade ebakindluseks. See on seotud ennekõike Eesti teaduse kroonilise alarahastusega, mis ühest küljest sunnib erialaselt töölt lahkuma ennast edukalt tõestanud ajaloouurijaid, kuid teisest küljest pärsib noorte ajaloolaste pühendumist akadeemilisele tööle. Kuid selle küsimuse juurde naasen veidi hiljem.

\section{KUS UURITAKSE EESTIS AJALUGU?}

Ajalooteadust teevad inimesed tavaliselt institutsioonide toel. Kui hakatuseks meenutada varasemat aega, siis hilisnõukogude Eestis uuriti ajalugu peamiselt kahes asutuses - Tartu Riikliku Ülikooli ajalooteaduskonnas, mis oli jagatud kahe kateedri, üldajaloo ja NSV Liidu ajaloo kateedri vahel, ja ENSV Teaduse Akadeemia Ajaloo Instituudis Tallinnas (asutatud 1947), kus töö toimus viies sektoris. Neile lisaks tegeldi ajaloo uurimisega EKP KK Partei Ajaloo Instituudis Tallinnas (1947-1990), samuti suuremates muuseumides ja arhiivides. Uurimistöö koondumine kahte keskusesse iseloomustab Eesti ajalooteadust veel selgi sajandil, kuigi iseseisvuse taastamise järel on tehtud mitu institutsionaalset reformi ja asutatud ka päris uusi

${ }^{25}$ Andmed on võetud andmebaasist Haridussilm; aastate 2000-2005 andmed puuduvad. 
uurimiskeskusi. Nagu eespool öeldud, reorganiseeriti Tartu Ülikooli ajaloo osakond 1990. aastate alguses seitsmeks õppetooliks, millest praeguseks on välja kasvanud kuus osakonda, mis tegutsevad ajaloo ja arheoloogia instituudi egiidi all (etnoloogia õppetool ühines filosoofiateaduskonna kultuuriteaduste instituudiga ja moodustas seal omaette osakonna). Eesti Teaduste Akadeemia Ajaloo Instituut muudeti 1997. aastal iseseisvaks teadus- ja arendusasutuseks, kuni see liideti 2005. aastal asutajaliikmena Tallinna Ülikooliga. 2015. aastal reorganiseeriti instituut TLÜ humanitaarteaduste instituudi ajaloo, arheoloogia ja kunstiajaloo keskuseks, mille kõrvale loodi ajaloo akadeemiline suund (s.t osakond). Mõlema ülikooli juures tegutsevad ka ühe või teise ajaloovaldkonna edendamisele pühendunud uurimiskeskused, nagu näiteks Tallinna Ülikoolis keskaja keskus (asutatud 2005) ja keskkonnaajaloo keskus (asu-tatud 2011), Tartu Ülikoolis ajaloo ja ühiskonnaõpetuse didaktika keskus (asutatud 2008) ning Lähis-Ida ja vahemeremaade vanade kultuuride uurimise keskus (asutatud 2014). Ajalooalase uurimistööga tegeletakse kitsama nurga alt teisteski Eesti ülikoolides, eeskätt Eesti Kunstiakadeemias ning Eesti Muusika- ja Teatriakadeemias. Spetsiifilistel ajalooteemadel koostatakse akadeemilisi uurimistöid ka Tallinna Tehnikaülikoolis, Kaitseväe Akadeemias ja Viljandi Kultuuriakadeemias.

Lähiajaloo uurimise valdkonnas on uuel sajandil oluliseks keskuseks kujunenud Eesti Mälu Instituut, mille asutamise algatas 2008. aastal president Toomas Hendrik Ilves. Õigupoolest on see käsitatav eelmise presidendi Lennart Meri poolt 1998. aastal kokku kutsutud Inimsusevastaste Kuritegude Uurimise Eesti Rahvusvahelise Komisjoni uurimisrühma järglasena, mis lõpetas tegevuse 2008. aasta detsembris. Eesti Mälu Instituut jätkas komisjoni alustatud tööd Saksamaa ja Nõukogude Liidu okupatsioonide ajal Eestis toime pandud inimsusvastaste kuritegude uurimise vallas, ent laiendas seda inimõiguste rikkumisele terve Nõukogude perioodi ulatuses. 2017. aastal ühines Eesti Mälu Instituut sihtasutusega Unitas uueks sihtasutuseks, mis lõimib inimvaenulike režiimide ja ideoloogiate alase akadeemilise uurimistöö sellega seotud teavitustööga. ${ }^{26}$

Traditsiooniliselt on ajaloolise uurimistöö keskused olnud arhiivid. Kui hilisnõukogude perioodil oli arhiivide juhtimine allutatud Arhiivide Peavalitsusele Moskvas (mida kohapeal esindas ENSV Arhiivide Peavalitsus), siis 1990. aastatel ennistati arhiivide iseseisev haldamine, moodustati Arhiiviamet ja 1998. aastal vastu võetud arhiiviseaduse alusel alustas järgmisest aastast tegevust Rahvusarhiiv, mis hõlmas ajalooarhiivi Tartus, riigiarhiivi ja filmiarhiivi Tallinnas ning 15 maa-arhiivi üle Eesti. Rahvusarhiiv kuulus Riigikantselei ametkonda ja seda juhtis riigiarhivaar.

\footnotetext{
${ }^{26} \mathrm{Vt}$ http://mnemosyne.ee/meist/ (10.08.2020). Laiema tausta koht vt: Pettai, E.-C. Estonian International Commission for the Investigation of Crimes against Humanity. - Encyclopedia of transitional justice. Ed. by L. Stan, N. Nedelsky. Vol. 1. Cambridge University Press, Cambridge, 2013, 117-121; Pettai, E.-C. Negotiating history for reconciliation: A comparative evaluation of Baltic presidential commissions. - Europe-Asia Studies, 2015, 67, 7, 1079-1101; Pettai, E.-C. Interactions between history and memory: Historical commissions and reconciliation. - Research companion to memory studies. Ed. by S. Kattago. Ashgate, Farnham, 2015, 237-250; Pettai, E.-C. Historical expert commissions and their politics. - The Palgrave handbook of state-sponsored history after 1945. Ed. by B. Bevernage, N. Wouters. Palgrave Macmillan, London, 2018, 687-712. Lähemalt lähiajaloo uutest uurimiskeskustest vt Toomas Hiio artiklit siinsamas ajakirjanumbris.
} 
2012. aastast kehtib Eestis uus arhiiviseadus, mille üheks põhieesmärgiks on õiguslike tingimuste loomine üleminekul digitaalsele dokumendi- ja arhiivihaldusele. Uue seadusega allutati Rahvusarhiiv haridus- ja teadusministeeriumile ning kehtestati uus juhtimisstruktuur. Viimase suurema muudatusena lõpetasid 2016. aastal eraldiseisvate üksustena tegevuse Riigiarhiiv ja Ajalooarhiiv. 2017. aastal avati Tartus Rahvusarhiivi uus peahoone Noora. ${ }^{27}$ Rahvusarhiiv on praeguseks sisuliselt sünonüümne Eesti arhiivisüsteemiga, sellest väljaspool tegutsevad üksnes Tallinna Linnaarhiiv ning Narva ja Maardu linnavalitsuse juures asuvad arhiivid. Kuigi akadeemiline uurimistöö ei ole olnud ei Rahvusarhiivi ega munitsipaalarhiivide põhitegevus, on siiski teadusürituste korraldamise, allikate publitseerimise, uurimistööde koostamise ja nende avaldamise vallas ära tehtud väga suur töö, mis ei jää palju alla ülikoolide panusele. Selle juures tuleb aga kohe toonitada ülikoolide ja arhiivide tihedat koostööd, sh töökohtade omavahelise jagamise osas.

Ülikoolide, uurimiskeskuste ja arhiivide kõrval on neljas Eesti ajalooteaduse institutsionaalne sammas muuseumid. Statistikaameti andmetel on Eestis praegu 180 muuseumi 244 külastuskohaga. ${ }^{28}$ Ajaloo- ja arheoloogiamuuseumeid on nende seas 49 , koduloomuuseume 85 , kunstimuuseume 18 ning etnograafia- ja antropoloogiamuuseume 8. Viimasel kahekümnel aastal on muuseumide asutamise trend olnud pigem tõusev, nii oli 2000. aastal muuseumeid (koos filiaalidega) kokku 183, sh ajaloo- ja arheoloogiamuuseumeid 32 (joonis 10). Eesti muuseumide tegevust korraldab ja koordineerib Kultuuriministeerium, õiguslikult reguleerib nende tegevust 2013. aastal vastu võetud muuseumiseadus (viimati muudetud 2019. aasta kevadel). ${ }^{29}$

Alates 2012. aastast on Eesti muuseumivõrgustik teinud läbi mitu muutust, sh juriidilises vormis. Riik on asutanud 13 uut muuseumide sihtasutust, kohalike omavalitsuste juhtida on antud 5 endist riigimuuseumi. ${ }^{30}$ 2020. aasta seisuga kuulub Kultuuriministeeriumi haldusalasse 7 riigimuuseumi (sh Eesti Rahva Muuseum) ja 13 sihtasutust (sh Eesti Ajaloomuuseum, Eesti Kunstimuuseum ja Eesti Meremuuseum), lisaks on nelja teise ministeeriumi valitsemisalas veel neli riigimuuseumi (sh Eesti sõjamuuseum Kaitseministeeriumi alluvuses). ${ }^{31}$

2018. aastal tehtud uuringu järgi töötab museoloogia valdkonnas kokku 1894 inimest, nende seas u 400 koguhoidjat ja teadur-kuraatorit, 70 konservaatorit, 150 külastusjuhti ja u 100 muuseumipedagoogi. ${ }^{32}$ Ajalooalane uurimistöö ei ole

${ }^{27}$ Vt lähemalt Pirsko, P. Eesti arhiivinduse arengufaasid. - Tuna, 2020, 1, 2-7; Uuet, L. Rahvusarhiiv kui riigiasutus. - Tuna, 2020, 1, 50-59; Kibal, B. Rahvusarhiiv kui riigiasutus: Teistmoodi vaatenurk ehk mõned täiendused Liivi Uueti samanimelisele artiklile Tunas 2020, nr. 1. - Tuna, 2020, 2, 142-151.

${ }^{28} \mathrm{Vt}$ https://www.stat.ee/stat-muuseumid (11.08.2020).

${ }^{29} \mathrm{https} / / /$ www.riigiteataja.ee/akt/110072013001? leiaKehtiv (11.08.2020).

${ }^{30}$ Muudatustest lähemalt vt https://www.kul.ee/et/muudatused-muuseumivorgustiku-korrastamisel (11.08.2020).

${ }^{31}$ Muuseumide nimekirja vt https://www.kul.ee/et/eesmargid-tegevused/muuseumid/muuseumidenimekiri (11.08.2020).

32 https://oska.kutsekoda.ee/wp-content/uploads/2017/10/OSKA-Kultuur-ja-loometegevus_Iosa_uuringuaruanne_2019_06.04.20.pdf(11.08.2020). 


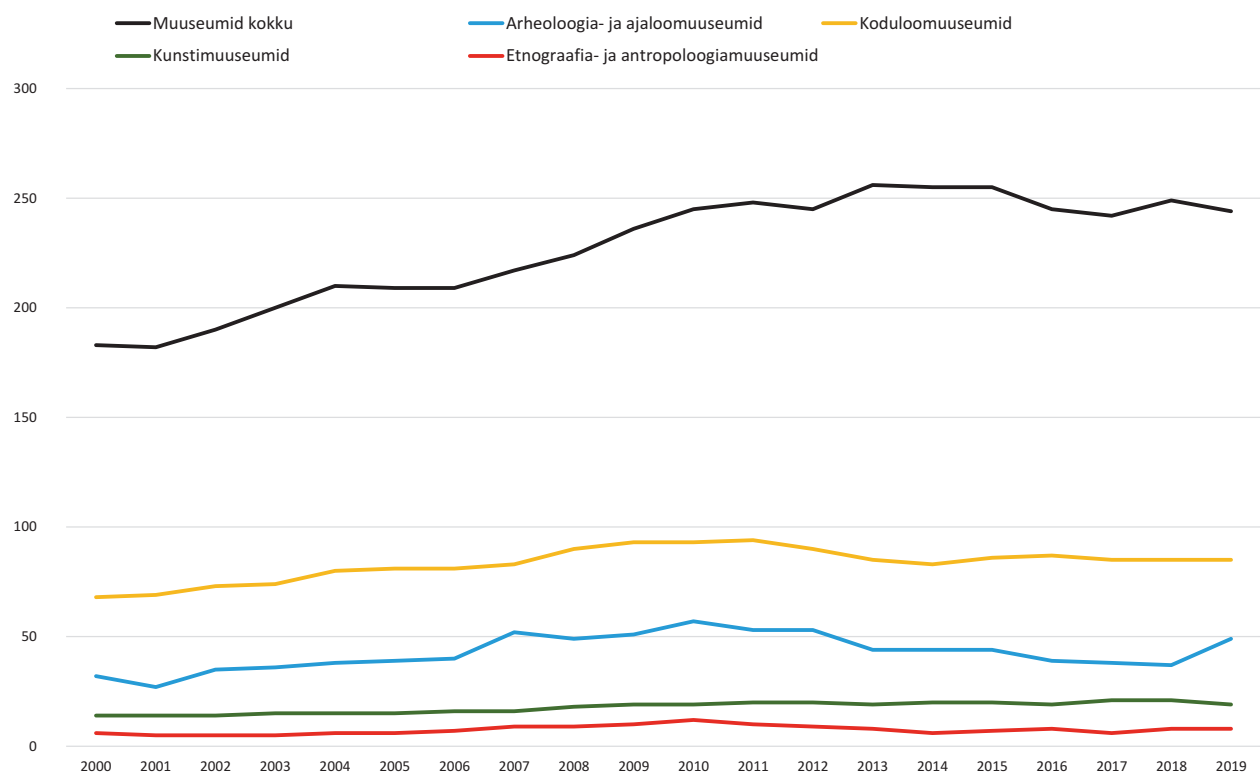

Joonis 10. Muuseumide arv Eestis aastatel 2000-2019. ${ }^{33}$

mõistagi enamikus muuseumides esikohal, kuid nagu tagapool, teaduspublitseerimisega seoses ilmneb, on muuseumide panus uute ajalooteadmiste loomisse siiski väga oluline. Eelduspäraselt on teadustöös suur roll kanda Eesti Ajaloomuuseumil, kus töötab mitu täiskohaga teadur-kuraatorit ja mille haare ulatub esiajaloo uurimisest tänapäevani välja. Kunstiajaloo vallas on keskne positsioon Eesti Kunstimuuseumil ja sõjaajaloo vallas Eesti Sõjamuuseumil - Kindral Laidoneri Muuseumil. Esile võib tõsta samuti tulemuslikku uurimistööd Läänemaa muuseumis, Tallinna Linnamuuseumis ja Tartu Ülikooli muuseumis. Lisaks oma põhitööle on argiajaloo uurimise vallas tähtsad Eesti Rahva Muuseum ja Eesti Vabaõhumuuseum.

Arhiivide ja muuseumide kõrval tuleb kesksetest mäluasutustest mainida veel teadusraamatukogusid, eeskätt Tartu Ülikooli raamatukogu ja Tallinna Ülikooli akadeemilist raamatukogu, samuti Eesti Kirjandusmuuseumi. TÜ raamatukogus tegutseb omaette teaduskeskus, kus on tööl 7 osakoormusega teadustöötajat, kellest enamik tegeleb ajalooliste teemadega. Siin vaadeldaval perioodil on korraldatud mitu teadusprojekti, sh väga olulised uuringud varauusaja raamatu-, keele- ja mõtteajaloo vallas. ${ }^{34}$ TLÜ akadeemilises raamatukogus on teadustöö põhiraskust kandnud vanaraamatu keskus (asutatud 2007) ning sellega seotud Baltika ja vanaraamatute säilitamise osakond, kus on tööl kümmekond teadurit ja spetsialisti. Eesti Rahvusraamatukogus on viimasel paaril kümnendil Piret Lotmani eestvedamisel tegeletud raamatukogunduse ning varauusaegse religiooni- ja kirjakultuuri ajaloo uurimisega. Eesti Kirjandusmuuseumis on ajalooalane teadustegevus koondunud

${ }^{33}$ Andmed on võetud 10.08.2020 seisuga Eesti Statistikaameti andmebaasist (http://andmebaas.stat.ee/ Index.aspx?lang=et\&DataSetCode=KU05).

${ }^{34} \mathrm{Vt}$ lähemalt https://utlib.ut.ee/projektid (10.08.2020). 
peamiselt Eesti Kultuuriloolisse Arhiivi, mille põhifookus on 20. sajandi kirjakultuuri ajalool.

Viimaks olgu olulise ajaloovälja institutsioonina ära nimetatud Eesti Muinsuskaitseamet (asutatud 1993), mis vastavalt 2019. aastal vastu võetud uuele muinsuskaitseseadusele vastutab lisaks mälestiste ja muinsuskaitsealasele järelevalvele ka muuseumivaldkonna arendamise eest. Muinsuskaitseamet ei tegele küll otseselt akadeemilise uurimistööga, ent panustab sellesse kaudselt väga mitmel moel (sh mälestiste inventeerimise, publitseerimistegevuse ja andmehaldusega).

Institutsioonide kõrval ja nendega koostöös kujundavad Eesti ajalooteaduse praktilist korraldust mitu erialast võrgustikku ja ühendust. Akadeemiliste ajaloolaste peamine ühing on 1999. aasta jaanuaris Tartu Ülikoolis taastatud Akadeemiline Ajalooselts, mille eelkäijaks on 1920-1941 Tartus tegutsenud samanimeline ühing. ${ }^{35}$ Põhikirjaliselt on seltsi eesmärk edendada ajaloo uurimist ja hoida ajalooteaduse akadeemilisi väärtusi, samuti toetada teaduslikke diskussioone, ajaloolaste koostööd ja ajaloo populariseerimist. ${ }^{36}$ Nagu eespool öeldud, kuulub praegu seltsi liikmete hulka sadakond ajaloolast (neist aktiivseid küll umbes veerand), ent seltsi tegevus on viimastel aastatel piirdunud peamiselt aastakoosoleku pidamisega ning keskse korraldava rolliga ajakirja Forschungen zur baltischen Geschichte ja ajalookirjanduse aastapreemia väljaandmisel. Tasub ehk samuti märkida, et Eesti on üks väheseid Euroopa riike, mille ajalooühing ei ole liitunud Rahvusvahelise Ajalooteaduste Komiteega (Comité international des Sciences historiques ehk CISH, asutatud 1926) ega saa seetõttu ametlikult osaleda iga viie aasta tagant toimuval suurel CISH-i rahvusvahelisel ajalookongressil. Akadeemilisest Ajalooseltsist aktiivsemad ja suurema liikmeskonnaga on ajaloovaldkonna kitsamad kutseühingud, nagu Eesti Arhivaaride Ühing ja Eesti Muuseumiühing. Esimene ennistati 1989. aastal, eeskujuks enne sõda lühikest aega (1939-1940) tegutsenud samanimeline organisatsioon. ${ }^{37}$ Vastavalt põhikirjale on Arhivaaride Ühingu eesmärk arhiivinduse alal tegutsevate isikute kutsealaste, õiguslike ja muude huvide kaitse, kutseoskuste arendamine, dokumentide kogumisele, korrastamisele, säilitamisele ja kasutamisele kaasaaitamine ning ajaloo ja arhiivinduse propageerimine. ${ }^{38}$ Eesti Muuseumiühing asutati 1988. aastal ja selle põhikirjaline eesmärk on aidata kaasa muuseumialase töö, sh teadustöö arengule Eestis ning kaitsta ja esindada oma liikmete töö- ja kutsealaseid õigusi ja huve. ${ }^{39}$ Seniajani tegutseb ka 1987. aastal loodud Eesti Muinsuskaitse Selts, mille kõrgaeg jääb küll 1980. aastate lõppu - 1990. aastate algusesse, ent mis ei ole minetanud oma rolli muinsushuviliste koondamisel. ${ }^{40}$ Spetsiifilisemaid seltsinguid leiab aja-

\footnotetext{
${ }^{35}$ Vt Kibal, B. Eesti ajalooteaduse tulevikusihid: Ülevaade jaanuarikuisest ajalookonverentsist ja Akadeemilise Ajalooseltsi taassünnist. - Ajalooline Ajakiri, 1999, 1, 96-101; Must, A. Akadeemilise Ajalooseltsi aruanne 1999. aasta tegevuse kohta. - Ajalooline Ajakiri, 2000, 1, 118-121. Sõjaeelse seltsi tegevusest vt: Kivimäe, J., Rosenberg, T. Akadeemilise Ajaloo Seltsi tegevusest (1920 1941). - Tartu Ülikooli ajaloo küsimusi XVI. Tartu Riiklik Ülikool, Tartu, 1985, 134-143.

${ }^{36}$ Akadeemilise Ajalooseltsi põhikiri. - Ajalooline Ajakiri, 1999, 1, 115-119.

${ }^{37}$ Vt https://eay.ee/ajalugu/ (11.08.2020); Pillak, P. Eesti Arhivaaride Ühing 70. - Tuna, 2010, 1, 146-148.

${ }^{38} \mathrm{https}: / /$ eay.ee/pohikiri/ (11.08.2020).

${ }^{39} \mathrm{https}$ ://www.muuseum.ee/wp-content/uploads/2018/01/EMU-pohikiri-2014.pdf (11.08.2020).

${ }^{40}$ Vt Eesti Muinsuskaitse Selts 25. Koost J. Tamm. Eesti Muinsuskaitse Selts, Tallinn, 2012.
} 
loovaldkonnast veelgi, nii koondab näiteks arheolooge Eesti Arheoloogiaselts (asutatud 1989), kunstiajaloolasi Eesti Kunstiteadlaste ja Kuraatorite Ühing (asutatud 1993 Eesti Kunstiteadlaste Ühinguna), sõjaajaloolasi Eesti Akadeemiline Sõjaajaloo Selts (asutatud 1988), kirikuajaloolasi Eesti Kirikuloo Selts (asutatud 1997) ja religiooniajaloolasi Eesti Akadeemiline Usundiloo Selts (asutatud 2006). ${ }^{41}$ Arvukatele genealoogiahuvilistele pakub ühistegevust Eesti Genealoogia Selts (asutatud 1990 ${ }^{42}$, aktiivsust pole minetanud ka pikkade juurtega Eesti Kodu-uurimise Selts (taasasutatud 1990), mis koondab praegu pea 200 koduloohuvilist. ${ }^{43}$ Baltisaksa ajaloopärandi huvilised on ühinenud Baltisaksa Kultuuri Seltsiks Eestis (asutatud 1988), millel praegu on 60 liiget. ${ }^{44}$ Ajaloolise uurimistöö edendamine on endiselt olulisel kohal ka Eesti vanimas teadusühingus Õpetatud Eesti Seltsis (taasasutatud 1988), mille ridadesse kuulub praegu 111 liiget (lisaks 17 auliiget). ${ }^{45}$

Üldistavalt võib öelda, et Eesti ajalooteaduse institutsionaalne ja organisatoorne korraldus on sel sajandil selgelt välja kujunenud ja võib eeldada, et lähitulevik enam suuremaid muutusi kaasa ei too. Akadeemilises ajaloouurimises on kuju võtnud kaks peamist keskust Tartu ja Tallinna Ülikooli näol, nende kõrval tehakse väga head ja olulist tööd arhiivides, muuseumides ja ülikooliraamatukogudes; iseseisvatest uurimiskeskustest tegutseb praegu aktiivselt vaid Eesti Mälu Instituut. Ajalooväljal leidub suur hulk eriilmelisi seltse ja ühinguid; mitte kõik nad ei ole võrdselt tegusad, ent vajadust uute kutseorganisatsioonide asutamise järele praegu ei paista.

\section{EESTI AJALOOTEADUSE RAHASTAMINE}

Inimeste ja institutsioonide tulemuslikkus ajalooteaduses sõltub palju neile eraldatud rahalistest vahenditest. See on paraku valdkond, kus king pigistab kõige enam, seda eriti viimasel kümnendil.

Nagu kogu Eesti teadust, nii on ka ajalooteadust sel sajandil mõjutanud oluliselt üleminek konkurentsipõhisele teadusrahastamise mudelile. ${ }^{46}$ Uue mudeli alguseks võib lugeda Eesti Teadusfondi (ETF) asutamist 1990. aastal. Kui esialgu otsustas ETF kõigi kolme teadusraha põhiliigi üle (individuaalsed ja institutsionaalsed uurimistoetused ning baasraha), siis 1997. aastal vastu võetud uue teadus- ja arendustegevuse seadusega anti viimase kahe otsustamisõigus Haridus- ja Teadusministeeriumile. Ministeeriumi juurde loodi nõuandev organ Teaduskompetentsi Nõukogu (TKN), mis hakkas konkursi korras jagama suurematele uurimisrühmadele mõeldud nn sihtfinantseeritud teadusteemasid. Kuni 2012. aastani tegutsesid ETF ja TKN rööpselt, esimene otsustas väiksemate individuaalsete uurimistoetuste ja teine suuremate

\footnotetext{
${ }^{41} \mathrm{Vt}$ vastavalt https://eass.ee/; https://kty.ee/; https://kirikulugu.ee/; https://eaus.ee/ (11.08.2020).

${ }^{42} \mathrm{http}: / /$ www.genealoogia.ee/ (11.08.2020).

${ }^{43} \mathrm{http}: / /$ www.ekus.ee/ (11.08.2020).

${ }^{44} \mathrm{http}: / /$ www.baltisaksaselts.ee/liikmed.html (11.08.2020).

$45 \mathrm{https}: / /$ oes.ut.ee/liikmed/ (11.08.2020).

${ }^{46}$ Eesti teaduse rahastamissüsteemi kujunemisest vt nt: Allik, J. Eesti teaduse lugu. - Akadeemia, 2005, 6, 963-985; 7, 1210-1229.
} 
rühmatoetuste üle. Vastavalt 2011. aastal vastu võetud uuele teadus- ja arendustegevuse seadusele alustas 2012. aastal ETF-i ja TKN-i järeltulijana tööd Eesti Teadusagentuur (ETAg), mis asus haldama kahte uut teadusrahastamise meedet: institutsionaalne uurimistoetus (IUT) ja personaalne uurimistoetus (PUT). Viimane suurem muudatus rahastamissüsteemis tehti 2015. aastal, kui lõpetati IUT-de väljaandmine ja selle asemel loodi uus PUT-de süsteem (järeldoktori, stardi- ja rühmagrandid). Kõik need heitlikud muutused on teadlaste vaatenurgast olnud seda keerulisemad, et viimased kümmekond aastat on riiklik uurimistoetuste rahastus püsinud paigal, kuigi elatustaseme tõus ja teadlaste juurdekasv on olnud kiire. See on seadnud Eesti ajalooteaduse kaunis täbarasse seisu, seda eriti suuremate algatuste, koostöö ja järelkasvu osas. Projektipõhine rahastusmudel on aga kindlasti kujundanud ka ajalooalase uurimistöö iseloomu, suunanud ajaloolasi otsima teemasid ja väljundeid, mis tagaksid tihedas konkurentsis suuremat edu. Oluline on siiski silmas pidada, et konkurentsipõhised meetmed ei moodusta ajalooalaste uurimistööde põhirahastust, vaid selle kõrval on väga oluline nii kõrghariduse rahastamine (sh rahvusteaduste professuurid), teadus- ja arendusasutuste baasraha (mis on viimastel aastatel hüppeliselt kasvanud, sh rahvusteadustele eraldatud summad) kui ka arhiivide, muuseumide ja raamatukogude töö finantseerimine. Viimastel aastatel on üha suurema kaaluga olnud ka Euroopa Liidu tõukefondide ja konkurentsipõhise teadusraha (nagu Euroopa Teadusnõukogu grandid) vahendid.

Järgnevas ülevaates keskendun siiski vaid kitsalt konkurentsipõhiselt jagatavale teadusrahale Eestis, hõlmates vaatlusse nii ajaloo, arheoloogia kui ka kunstiajaloo valdkonna viimasel kahel kümnendil. Kui alustada uurimisprojektide arvust, siis avaneb võrdlemisi hüplik pilt, isegi kui langustrend on viimasel kümnendil selge (joonis 11). Joonisel nähtav on aga selles mõttes eksitav, et sisaldab rahalises mahus väga erinevaid granditüüpe (väikestest ETF-i grantidest kuni suurte IUT-deni), nii et parema üldpildi saab siis, kui vaadata valdkonna finantseerimist rahalises väärtuses (joonis 12). Sellest nähtub, et rahastamine tõusis püsivalt kuni 2013. aastani ja kukkus siis allapoole, kuni uue väikese tõusuni 2020. aastal. Summades on tõus kahekümne aastaga olnud siiski märkimisväärne: esimeste aastate mõnekümnetuhande euro asemel on praegu aastane toetussumma üle miljoni euro.

Kui süveneda eri granditüüpidesse, siis peegeldab see mõistagi esmajoones Eesti teadusrahastamise süsteemi heitlikkust, samuti selget liikumist suurematelt institutsionaalsetelt grantidelt väiksemate personaal- ja rühmagrantide suunas (joonis 13). Kui viimase kahekümne aasta rahaeraldised kokku liita, siis on Eesti riik investeerinud konkurentsipõhist grandiraha ajaloo, arheoloogia ja kunstiajaloo valdkonda 13345417 eurot. (Nagu öeldud, üldpildi saamiseks tuleb sellele liita baasfinantseerimise vahendid, samuti kõrghariduse rahastamine, ent seda ei ole võimalik ajaloovaldkonnas eraldi välja arvutada.) Ehkki rahanumbrites on ajaloovaldkonna rahastamise kasv olnud selge, siis teadlase vaates on kõige kõnekam näitaja projektitaotluste edukusprotsent. Joonis 14 näitab kujukalt, kuidas viimasel kümmekonnal aastal on käärid esitatud ja rahastatud taotluste vahel aina kasvanud, s.t järjest väiksem hulk esitatud projektidest on leidnud finantseerimist. Edulävendi protsent 


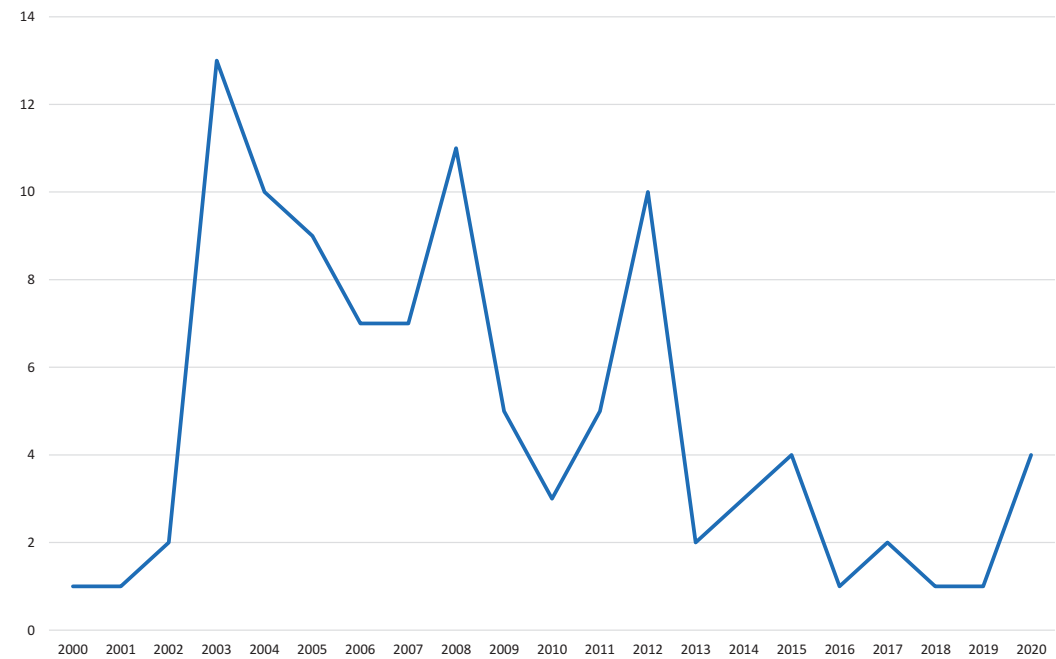

Joonis 11. Ajaloo, arheoloogia ja kunstiajaloo valdkonnas rahastatud teadusprojektide arv Eestis aastatel 2000-2020.47

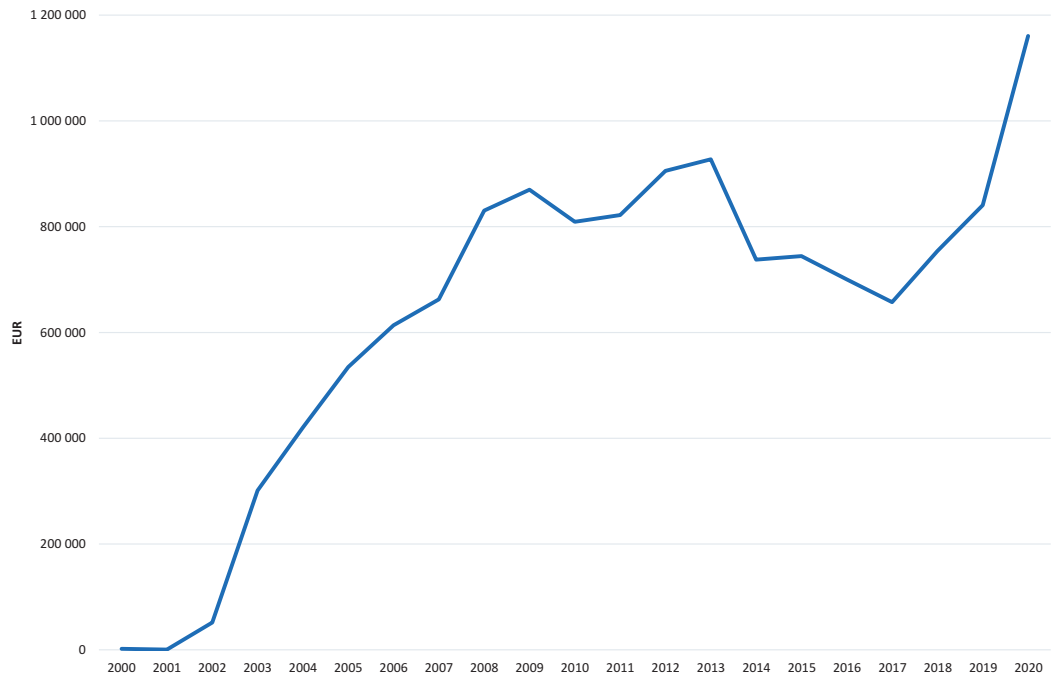

Joonis 12. Ajaloo, arheoloogia ja kunstiajaloo teadusprojektide rahastamine Eestis aastatel 2000 2020.48

${ }^{47}$ Andmed on võetud ETIS-est (https://www.etis.ee/) seisuga 14.07.2020. Arvud sisaldavad ETF-i grantide, HTM-i sihtfinantseeritud teadusteemade, ETAg-i personaalse ja institutsionaalse uurimistoetuse ning stardi- ja rühmagrantide andmeid. Ajaloo ja kunstiajaloo valdkonna projektidena on arvesse võetud projektid, milles ajaloo või kunstiajaloo osakaal on esitatud vähemalt $50 \%$. Ajaloo valdkonnana on arvestatud Frascati käsiraamatu valdkonda „6.1. Ajalugu ja arheoloogia“, varasema klassifikaatori versiooni järgi „6.1. Ajalugu (üldajalugu, eelajalugu, arheoloogia, numismaatika, paleograafia, genealoogia jne)“". Kunstiajaloo valdkonnana on arvestatud CERCS-i (Euroopa Komisjoni teadusvaldkondade klassifikaatori) valdkonda „H310 Kunstiajalugu“.

${ }^{48}$ Andmed on võetud ETIS-est seisuga 14.07.2020. Institutsionaalse uurimistoetuse summad on esitatud ilma üldkuluta. Andmete valiku põhimõtted on samad, mis kirjeldatud viites 47 


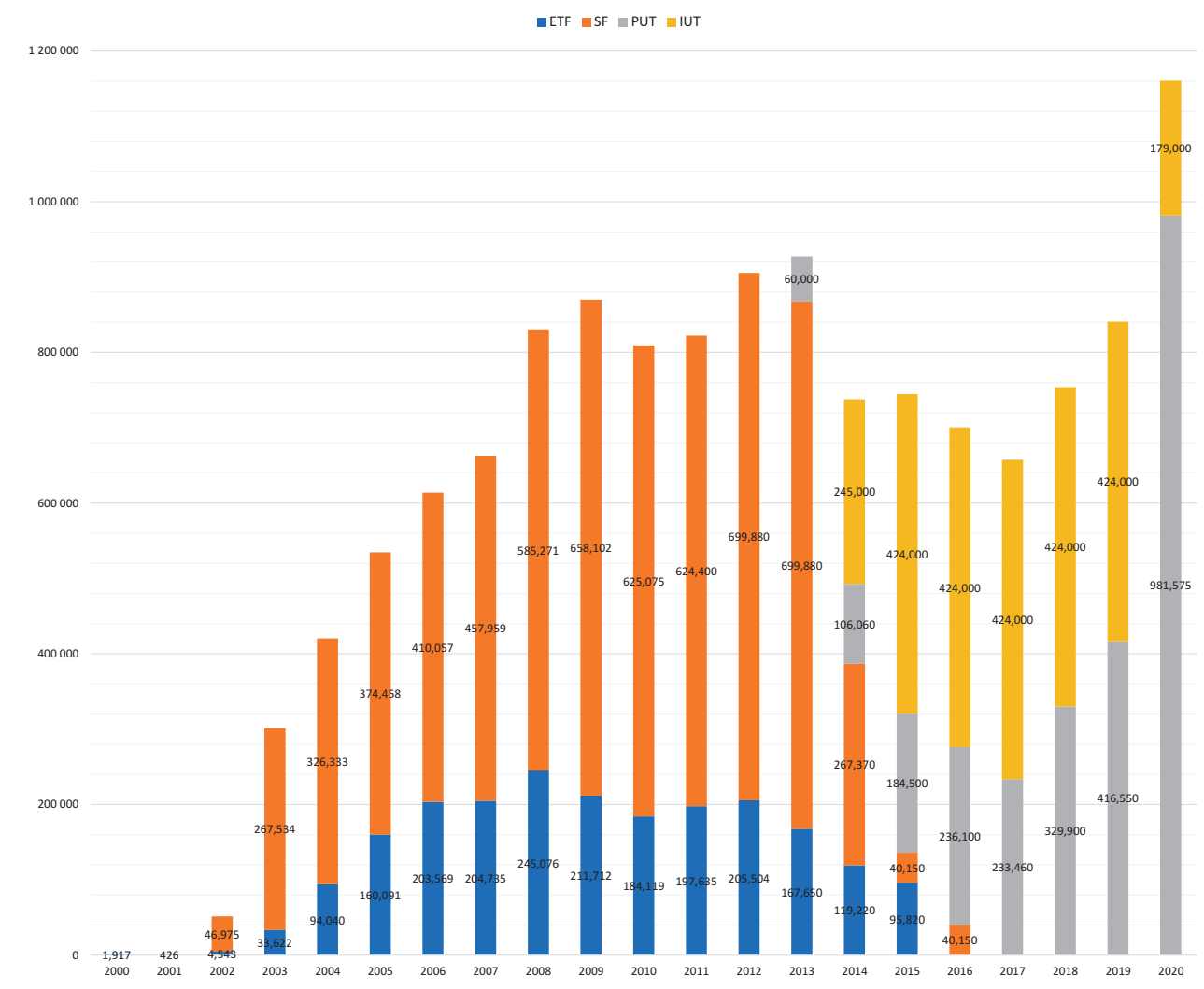

Joonis 13. Ajaloo, arheoloogia ja kunstiajaloo projektidele Eestis väljamakstud summad granditüüpide kaupa aastatel 2000-2020. ${ }^{49}$

püsis pikka aega $20-30 \%$ kandis, mida võib pidada heaks rahvusvaheliseks standardiks, ent alates 2015. aastast on taotluste edukusprotsent kukkunud 6-14\% vahele (tehes väikese tõusu vaid viimasel aastal), mis on ilmselgelt liiga madal, et tagada valdkonna kestlik areng ja muuta konkurentsis osalemine teadlastele motiveerivaks (joonis 15). Olgu lisatud, et see konkurentsinäitaja jääb selgelt alla ETAg-i grandikonkursi keskmisele näitajale, mis on viimasel viiel aastal olnud keskmiselt $20 \%$.

Eesti ajalooteaduse konkurentsipõhise rahastamise kohta viimasel kahel kümnendil saab teha kahetise üldistuse. Ühest küljest on valdkonna rahastus aastate jooksul oluliselt kasvanud ja võib eeldada, et vajadus oma ideid rahvusvaheliselt veenva projektina esitada on kaasa aidanud Eesti ajaloolaste paremale läbilöögivõimele globaalsel teadusareenil. Teisest küljest on projektitaotluste edukusnäitaja kukkunud selgelt alla mõistliku piiri, mis tähendab, et absoluutne enamus ajalooalastest grandiprojektidest on viimastel aastatel jäänud rahastamata, sh väga tugevad ja olu-

${ }^{49}$ Andmed on võetud ETIS-est 14.07.2020. Institutsionaalse uurimistoetuse summad on esitatud ilma üldkuluta. Andmete valiku põhimõtted on samad, mis kirjeldatud viites 47. 


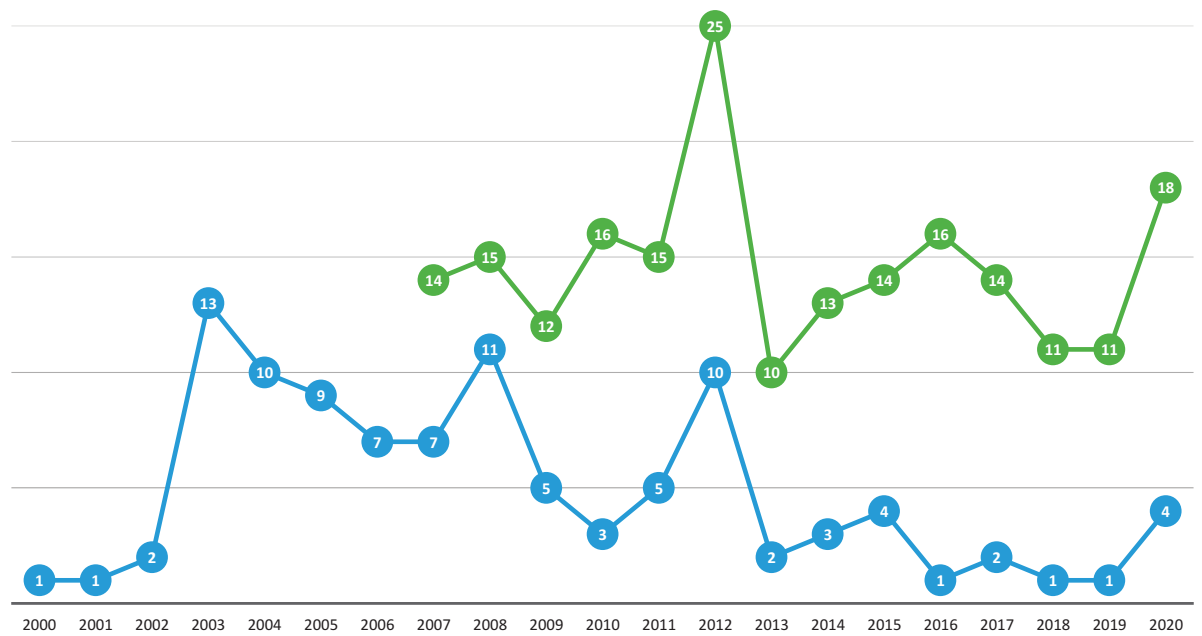

Joonis 14. Esitatud ja rahastatud projektitaotluste arv ajaloo, arheoloogia ja kunstiajaloo valdkonnas Eestis aastatel 2000-2020.50

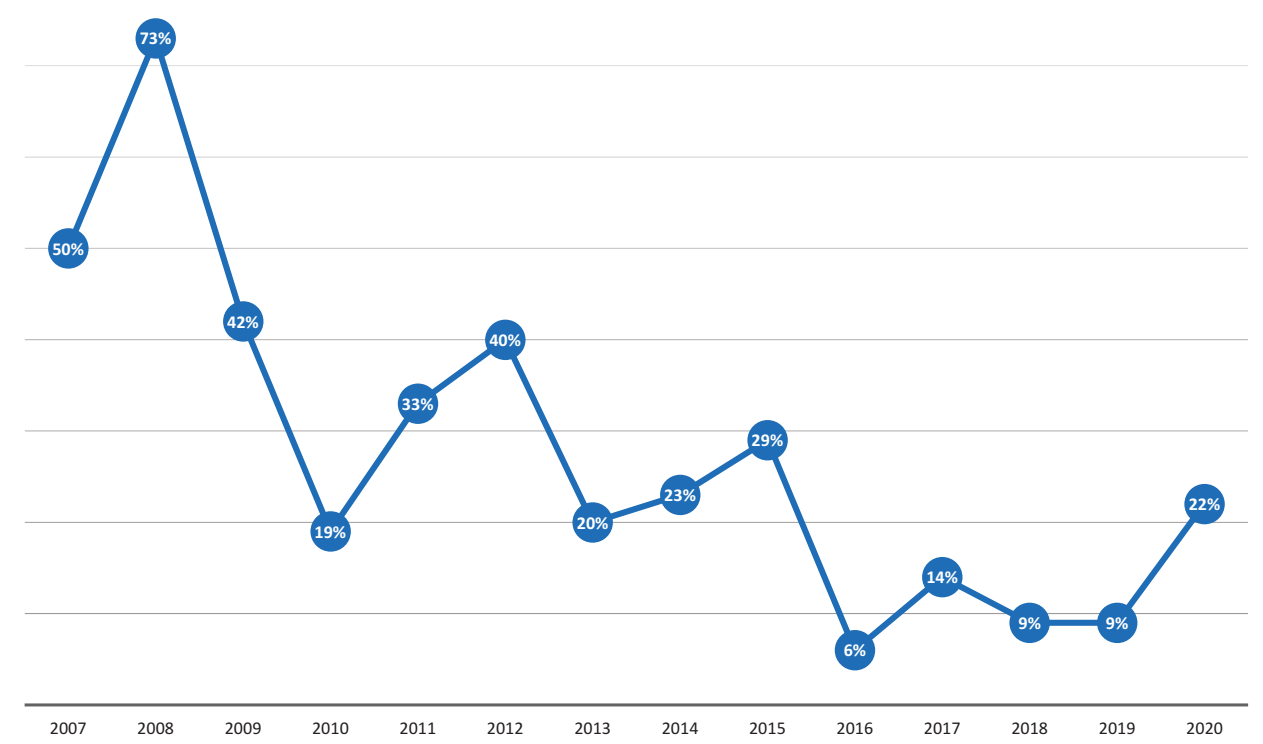

Joonis 15. Ajaloo, arheoloogia ja kunstiajaloo valdkonnas esitatud taotluste rahastamise protsent Eestis aastatel $2007-2020 . .^{51}$

${ }^{50}$ Andmed on võetud ETIS-est 14.07.2020. Aastatel 2000-2006 esitatud taotluste arvu kohta andmed puuduvad. Andmete valiku põhimõtted on samad, mis kirjeldatud viites 47.

${ }^{51}$ Andmed on võetud ETIS-est 14.07.2020. Aastatel 2000-2006 esitatud taotluste arvu kohta andmed puuduvad, mistõttu pole võimalik edukusprotsenti arvutada. Andmete valiku põhimõtted on samad, mis kirjeldatud viites 47 . 
lised taotlused (parimal juhul on need saanud kompensatsiooniks oluliselt väiksema toetuse ülikoolide baasrahast). See omakorda on seadnud löögi alla ülikoolide juures teaduritena töötavad ajaloolased, mis võib senise olukorra jätkudes päädida sellega, et kogu akadeemiline ajaloouurimine jääbki vaid õppejõudude ning muuseumi- ja arhiivitöötajate õlgadele. Arvestades aga kõrghariduse rahastamise aastatepikkust külmutamist, samuti palgaraha kroonilist nappust mäluasutustes, ei tundu seegi perspektiiv kuigi kestlik. Seega võib resümeerida, et Eesti ajalooteaduse üks olulisi ülesandeid edaspidi on saavutada stabiilne ja senisest paremini rahastatud teadusfinantseerimise süsteem, ent samuti püüda senisest enam ja edukamalt teadustööks vahendeid hankida Euroopa Liidu programmidest, võimalusel ka eratoetajatelt.

\section{KUS JA KUI PALJU EESTI AJALOOLASED PUBLITSEERIVAD?}

Nagu armastab rõhutada Eesti Teaduste Akadeemia president Tarmo Soomere, siis koosneb teadus kahest komponendist: uue teadmise loomisest ja selle kommunikatsioonist teistele. ${ }^{52}$ Ajalooteadusliku kommunikatsiooni ehk uurimistöö tulemuste publitseerimise valdkonnas on viimaste kümnendite muutused olnud erakordselt suured, mistõttu väärib teema veidi üksikasjalikumat tähelepanu. Käsitlen seda kahe nurga alt: alustuseks vaatan, millised on sel sajandil olnud peamised erialased kommunikatsioonikanalid, teiseks aga püüan mõõta ja iseloomustada Eesti ajaloolaste üldist teadusproduktsiooni vaatlusalusel perioodil.

Kui mõelda ennast nõukogude aja lõppu, siis olid Eesti ajaloolaste toonased võimalused uurimistöö tulemuste jagamiseks väga napid. Sel ajal ei ilmunud Eestis ühtegi ajalooteaduslikku ajakirja, üksnes mõned toimetiste sarjad Tartu ülikooli ja Teaduste Akadeemia juures. ${ }^{53}$ Esimeseks pääsukeseks võib pidada 1988. aastal asutatud ajalooajakirja (esialgse alapealkirjaga „Teaduslik-populaarne ajaloo almanahh") Kleio, mis lõpetas ilmumise 1997. aasta 4. numbriga. 1998. aastal hakkas selle asemel ilmuma Ajalooline Ajakiri (peatoimetaja Aadu Must, 2006-2018 Pärtel Piirimäe, alates 2019 Janet Laidla), mis esialgu oli mõeldud rööpselt taastatud Akadeemilise Ajalooseltsi häälekandjaks, sooviga jätkata sõjaeelset traditsiooni. ${ }^{54} \mathrm{Sa}$ jandivahetusest kujunes aga Eesti ajalooperioodika tõeline pöördepunkt, sest paralleelselt Ajaloolise Ajakirja taasasutamisega loodi Teaduste Akadeemia Kirjastuse juurde 1997. aastal uus ajalooajakiri Acta Historica Tallinnensia, mille eestve-

\footnotetext{
${ }^{52} \mathrm{Vt}$ nt Soomere, T. Inimliku teaduskommunikatsiooni võimalikkusest. - Sirp, 06.01.2017.

${ }^{53}$ Nt Tartu Riikliku Ülikooli sarjad „Eesti NSV ajaloo küsimusi“ (1960-1989), „Töid NLKP ajaloo alalt“ (1961-1988), „Skandinaavia kogumik“ (1962-1990), „Uurimusi Läänemeremaade ajaloost“ (1973-1992), ja ENSV Teaduste Akadeemia toimetised. Ühiskonnateadused (1967-1991).

${ }^{54}$ Vt Must, A. Eesti akadeemilise ajalooperioodika järjepidevus: Ajalooline Ajakiri ja Kleio. - Ajalooline Ajakiri, 1998, 1 (100), 5-12. Järjepidevust demonstreerib taastatud ajakirja numeratsioon, mis võtab arvesse nii sõjaeelse Ajaloolise Ajakirja, 1941. aastal ilmunud Ajaloo Ajakirja kolm numbrit kui ka Kleio numbrid. Sõjaeelse ajakirja kohta vt: Rosenberg, T. Ajalooline Ajakiri 1922-40. - Kleio, 1993, 8, 26-35. Vt ka ajakirja kodulehte veebis https://ojs.utlib.ee/index.php/EAA/index (11.08.2020).
} 
dajad olid Ajaloo Instituudi teadlased (peatoimetaja Priit Raudkivi, 2006-2019 Maie Pihlamägi, alates 2020 Marek Tamm). Käesolev teemanumber on ajakirja 26. number. ${ }^{55}$ Eesti Arhivaaride Ühingu egiidi all nägi 1998. aastal ilmavalgust veel kolmaski ajalooajakiri, sedapuhku veidi laiemale lugejaskonnale mõeldud Tuna (peatoimetaja Ott Raun), mis on sel sajandil tõusnud kõige loetumaks akadeemiliseks ajalooajakirjaks Eestis. ${ }^{56}$ Tegin kiire arvestuse, et Ajaloolises Ajakirjas on aastatel 2000-2019 ilmunud kokku 158 uurimuslikku artiklit, neist eesti keeles 128, inglise keeles 36 ja saksa keeles 4. Acta Historica Tallinnensia on samal perioodil avaldanud 145 uurimuslikku artiklit, neist eesti keeles 105, inglise keeles 36 ja saksa keeles 4. Kõige tulemuslikum, vähemalt arvuliselt, on olnud aga Tuna töö, sest ajakirjas on kõnealustel aastatel ilmunud 420 uurimuslikku artiklit (kõik eesti keeles, kui välja arvata üks ingliskeelne ja kaks venekeelset erinumbrit, mis koosnevad valdavalt varem avaldatud artiklite tõlgetest). Kokku on niisiis kolmes peamises ajalooajakirjas avaldatud 723 algupärast uurimuslikku artiklit, mis tähendab keskmiselt pea iga nädal üht artiklit. ${ }^{57}$

Kuid nende kolme valdavalt eestikeelse ajalooajakirja kõrval ilmub Eestis sel sajandil hulk teisigi, kitsama suunitlusega või võõrkeelseid ajalooajakirju ja -aastaraamatuid. Kui liikuda kronoloogilises järjekorras, siis tuleb esimesena mainida Raimo Pullati algatusel 1991. aastal taastatud väljaannet Vana Tallinn, mis jätkas 1936-1939 ilmunud samanimelise aastaraamatu sihte linnaajaloo edendamisel. ${ }^{58}$ Alates 2015. aastast üllitab aastaraamatut Tallinna Linnaarhiiv (peatoimetaja Juhan Kreem) ja praeguseks on väljaanne jõudnud 30. köiteni. ${ }^{59}$ 1997. aastal sündisid rööpselt kaks arheoloogide uut perioodilist väljaannet, ajakiri Estonian Journal of Archaeology / Eesti Arheoloogia Ajakiri ning aastaraamat Archaeological Fieldwork in Estonia / Arheoloogilised välitööd Eestis (AVE). Kui esimene avaldab kaks korda aastas peamiselt ingliskeelseid erialaseid artikleid nii Eesti kui ka välisautoritelt, siis teine pakub inglise ja saksa keeles aruandeid viimase aja olulisematest arheoloogilistest välitöödest Eestis, jätkates 1974. aastal ENSV TA toimetiste sarjas alustatud traditsiooni. Estonian Journal of Archaeology (peatoimetaja Valter Lang) ilmub Teaduste Akadeemia Kirjastuse alt ja selle toimetamise eest seisavad hea Tartu Ülikooli ajaloo ja arheoloogia instituut ning Tallinna Ülikool. ${ }^{60}$ AVE ilmub Muinsuskaitseameti, Tartu Ülikooli ja Tallinna Ülikooli koostöös. 2006. aastal hakkas Akadeemilise Ajalooseltsi egiidi all ilmuma uus, valdavalt saksakeelne ajalooajakiri Forschungen zur baltischen Geschichte (peatoimetajad Karsten Brüggemann

${ }^{55} \mathrm{Vt}$ https://kirj.ee/historica/ (11.08.2020).

${ }^{56} \mathrm{Vt}$ http://www.ra.ee/tuna/ (11.08.2020).

${ }^{57}$ Andmed pärinevad ISE andmebaasist (https://artiklid.elnet.ee/search $\sim \mathrm{S} 1$ *est), ent on käsitsi puhastatud, et välja selekteerida vaid uurimuslikud artiklid, s.t arvestuses ei kajastu raamatuarvustused, juubeliartiklid, nekroloogid, teaduselu kroonika jms.

${ }^{58}$ Samal, 1991. aastal asutati veel teinegi sariväljaanne, nimelt arheoloogide „Muinasaja teadus“ (peatoimetaja Valter Lang), mida on praeguseks välja antud 28 köidet.

${ }^{59}$ Vt Raudkivi, P. „Vana Tallinna“ mitu tulemist. - Tuna, 2016, 2, 153-154.

${ }^{60} \mathrm{Vt}$ https://kirj.ee/archaeology/ (11.08.2020). Arheoloogide perioodilistest väljaannetest üldiselt vt: Tamla, Ü. Publications on archaeology in Estonia, 1990-2008. - Lietuvos Archeologija, 2009, 35, 137-142. 
ja Mati Laur). Kord aastas ilmuv väljaanne on pühendatud peamiselt Eesti ja Läti ajaloole ning seda toimetatakse korraga Tartu ja Tallinna Ülikoolis. Seni on ilmunud 15 numbrit. ${ }^{61}$ Järgmisest aastast on aastaraamatu ametlik väljaandja rahvusvaheline Ferdinand Schöninghi kirjastus (kuulub Brillile). Kunstiajaloolaste kaks peamist häälekandjat on Kunstiteaduslikke Uurimusi, mis asutati juba 1976. aastal, ent ilmus kuni 2002. aastani mitteperioodilise kogumikuna, ja 2009. aastal Tartu Ülikooli juurde loodud ajakiri Baltic Journal of Art History. Kunstiteaduslikke Uurimusi (peatoimetaja Virve Sarapik) ilmub 2003. aastast neli numbrit aastas ja seda annab välja Eesti Kunstiteadlaste ja Kuraatorite Ühing; ajakiri avaldab eesti- ja ingliskeelseid uurimusi kunstiajaloo, -teooria ja visuaalkultuuri vallast. ${ }^{62}$ Baltic Journal of Art History (peatoimetaja Juhan Maiste) on kaks korda aastas ilmuv Tartu Ülikooli ajaloo ja arheoloogia instituudi kunstiajaloo osakonna ajakiri, mis avaldab kunstiajaloolisi kaastöid inglise ja saksa keeles. Siiani on ilmunud 19 köidet. ${ }^{63}$ Sõjaajaloolaste artikleid nii eesti kui ka inglise keeles avaldab Eesti sõjaajaloo aastaraamat (peatoimetaja Toomas Hiio), mis asutati 2011. aastal ja mida annavad välja Eesti Sõjamuuseum - Kindral Laidoneri Muuseum ja Tallinna Ülikooli kirjastus. Seni on ilmunud üheksa köidet. ${ }^{64}$

Loetletud üheksa akadeemilise ajakirja/aastaraamatu kõrval on viimasel kümnendil hakanud eesti keeles ilmuma ka hulk populaarteaduslikke ajalooajakirju. Neist kõige loetum on valdavalt tõlkesisuga Imeline Ajalugu (alates 2011), mida täiendab algupärase sisuga Eesti Ajalugu (alates 2017). Nende kõrval tuleb esile tõsta algupärast populaarteaduslikku arheoloogiaajakirja Tutulus (alates 2012). Aastatel 2016-2018 ilmus samuti tõlgitud sisuga ajakiri Ajalugu. Jätkuvalt avaldab populaarteaduslikke ajalooartikleid 1967. aastast tegutsev ajakiri Horisont. Lisaks ei saa kindlasti tähelepanuta jätta SA Kultuurilehe ajakirju Akadeemia, Looming, Keel ja Kirjandus ning Vikerkaar, mis avaldavad võrdlemisi sageli ajalooalaseid artikleid. Oma kitsas ajaloonišis tegutseb ajakiri Kultuur ja Elu.

Ülikoolide ja kirjastuste kõrval on perioodiliste ajalooväljaannete üllitamisel väga aktiivsed Eestis tegutsevad mäluasutused. Läheb pikale, et neil kõigil siinkohal peatuda, ent minu andmetel ilmub Eestis praegu vähemalt 30 arhiivide ja muuseumide rohkem või vähem regulaarset toimetiste sarja ${ }^{65}$ Neist kõige vanem ja pres-

${ }^{61} \mathrm{Vt} \mathrm{http://fzbg.ut.ee/} \mathrm{(11.08.2020).}$

${ }^{62} \mathrm{Vthttps} / /$ ktu.kty.ee/ (11.08.2020).

${ }^{63} \mathrm{Vt} \mathrm{https://ojs.utlib.ee/index.php/bjah/index} \mathrm{(11.08.2020).}$

${ }^{64} \mathrm{Vt}$ http://publications.tlu.ee/index.php/eymh/index (11.08.2020). Selle eelkäija oli Hannes Walteri algatusel asutatud Laidoneri muuseumi aastaraamat (ilmus kuus numbrit 2001-2006). Artikleid sõjaajaloost ilmus ka 1993-2015 Kaitseväe Ühendatud Õppeasutuste kirjastamisel ilmunud sarjas KVÜÕA toimetised, mida 2016. aastal jätkas ajakiri Sõjateadlane / Estonian Journal of Military Studies. Nüüdseks on seda vahepeal Eesti Kaitseväe Akadeemiaks ümbernimetatud õppeasutuse kirjastatuna ilmunud 13 numbrit. Vt https://www.ksk.edu.ee/en/research/estonian-journal-of-military-studies-1/ (11.08.2020).

${ }^{65}$ Põhjalikuma ülevaate mäluasutuste kirjastustegevusest pakuvad kaks Tallinna Ülikoolis kaitstud magistritööd: Tuuling, L. Muuseumite kirjastustegevus Eestis 2011-2015. Magistritöö. Tallinna Ülikool, Digitehnoloogiate instituut, Tallinn, 2016 (võrguteavik); Kannik, T. Arhiivide kirjastustegevus Eestis: Olukorra kaardistus. Magistritöö. Tallinna Ülikool, Digitehnoloogiate instituut, Tallinn, 2017 (võrguteavik). Pikemas ajalõikes pakuvad informatsiooni arhiivide kirjastustegevusest 
tiižikam on Rahvusarhiivi toimetised / Acta et commentationes Archivi Nationalis (peatoimetaja Tõnu Tannberg), mis selle nime all on ilmunud 2017. aastast, ent mis jätkab 1931-1938 ilmunud Eesti Riigi Keskarhiivi toimetiste sarja, mis taastati 1996. aastal Eesti Ajalooarhiivi toimetiste nime all. Sarjas on siiani ilmunud 34 köidet. Aastasse 1975 ulatub tagasi toimetiste sari „Tartu Ülikooli ajaloo küsimusi“ (peatoimetaja Lea Lepik), mida praeguseks on ilmunud 47 köidet. Oma toimetisi üllitab Tallinna Linnaarhiiv (aastast 1996), kus siiani on avaldatud 15 nimetust. Toimetiste sari on pea iga aktiivsema muuseumi juures, neist olulisematena võib esile tuua Eesti Ajaloomuuseumi toimetisi „Varia historica“ (alates 2006), Eesti Kunstimuuseumi toimetisi (alates 2007), Läänemaa muuseumi toimetisi (alates 1997), Narva Muuseumi toimetisi (alates 1999), Eesti Meremuuseumi toimetisi (alates 1999), Eesti Sõjamuuseumi - Kindral Laidoneri Muuseumi toimetisi (alates 2004) ja Saaremaa Muuseumi toimetisi (alates 2012). Kõige viimasena on ilmuma hakanud Eesti Mälu Instituudi toimetised (alates 2018), Tallinna Linnamuuseumi toimetised (alates 2019) ja Eesti Maanteemuuseumi toimetised (alates 2019) (viimased kaks jätkavad varasemat aastaraamatute traditsiooni). Kogutud statistika lubab teha kokkuvõtte arhiivide publitseerimisaktiivsusest kõikide teavikute lõikes viimasel kahel kümnendil (vt joonis 16). Jooniselt on näha, et keskmiselt avaldavad Rahvusarhiiv ja Tallinna Linnaarhiiv aastas 5-8 teavikut; rekordaastal 2006 ilmus kokku 15 teavikut.

Lisaks ajakirjadele, aastaraamatutele ja toimetistele ilmub Eestis ajaloovallas mõistagi suur hulk monograafiaid ja artiklikogumikke, samuti olulisi uurimuste sarju, mille üle paraku eraldi üksikasjalikumat statistikat ei koguta. Seega on keeruline öelda, kui palju algupäraseid ajalooraamatuid Eestis igal aastal ilmub. Statistikaameti andmebaas lubab teha väljavõtte kõigi sel sajandil valdkonnas „biograafia, genealoogia ja ajalugu“ ilmunud trükiraamatute kohta, hõlmates nii algupärandeid kui ka tõlkeid (joonis 17). Selle järgi otsustades oli ajalookirjanduse kõrgaeg Eestis eelmise kümnendi lõpus, samas kui viimastel aastatel võib täheldada nimetuste arvus mõningat langustrendi; väga tõenäoliselt saab seda aga seletada Eesti raamatuturu üldise kahanemisega samal ajal. Eesti rahvusbibliograafia andmetel ilmus teemal „Eesti ajalugu“ aastatel 2000-2019 kokku 1781 raamatunimetust, teemal „arheoloogia“ 167 nimetust ja teemal „ajalooteadus, arhiivindus“ 85 nimetust (kunstiajalugu omaette teemana bibliograafias ei ole). ${ }^{66}$

Ajalooraamatute turul etendavad ülikoolide ja mäluasutuste kõrval märkimisväärset rolli erakirjastused, mis lisaks tõlkekirjandusele avaldavad sageli ka Eesti ajaloolaste uurimusi. Kõige süsteemsemat tööd on selles vallas teinud Argo kirjas-

järgmised artiklid: Küng, E. Publitseerimistööst Eesti Ajalooarhiivis 1994-1998. - Tuna, 1998, 1, 151-152; Kõiv, L. Publitseerimistööst Tallinna Linnaarhiivis 1993-2000. - Tuna, 2001, 1, 154 155; Küng, E. Kirjastuse Eesti Ajalooarhiiv publitseermistegevus 1999-2000. - Tuna, 2001, 1, 153-154; Tannberg, T. Rahvusarhiivi teadus- ja publitseerimistegevuse kümmeaastaku piirjooni. Rahvusarhiivi tegevuse ülevaade 2007-2008: Kümme aastat rahvusarhiivi. Koost T. Tannberg, Rahvusarhiiv, Tartu, 2010, 44-51.

${ }^{66}$ Eesti Rahvusbibliograafia - statistika: teemad, https://erb.nlib.ee/statistika?leht=teemad\&aa=2000 \&ak=2019 (11.08.2020). 


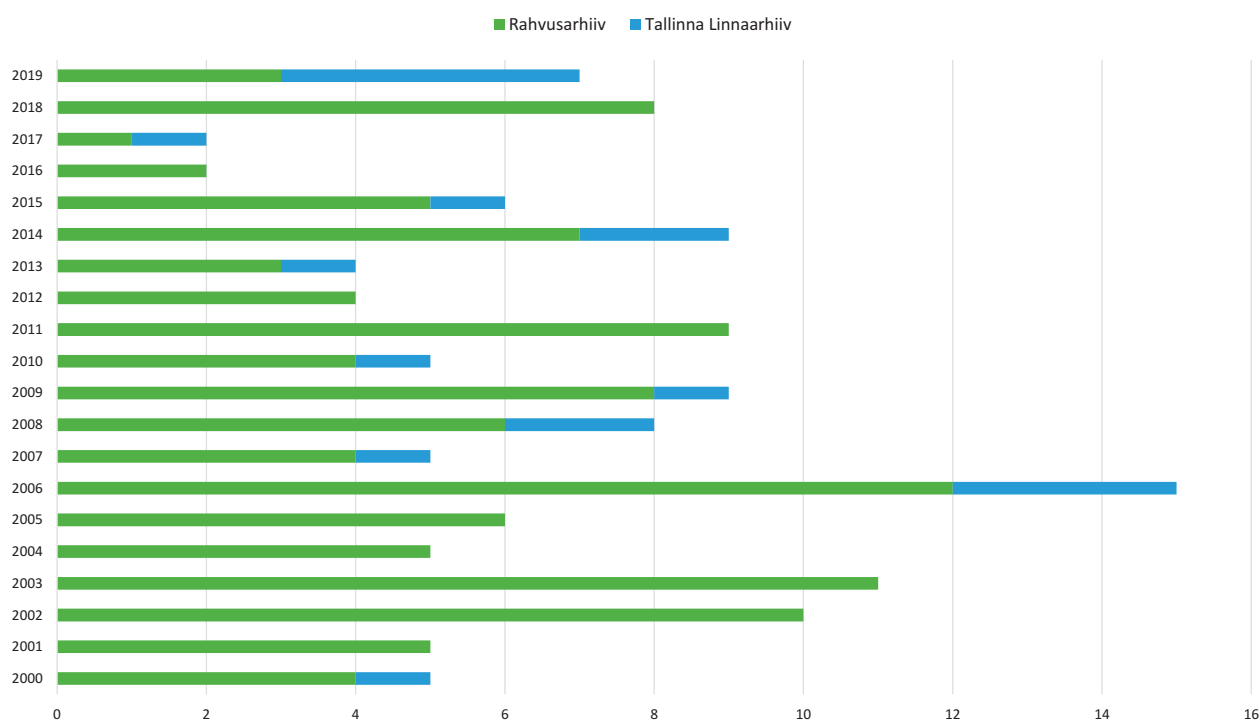

Joonis 16. Arhiivide kirjastatud teavikud Eestis aastatel 2000-2019. ${ }^{67}$

250

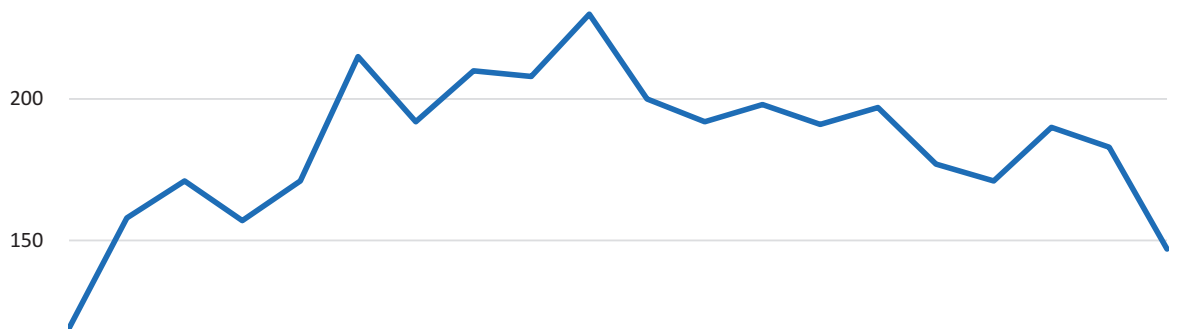

100

50

20002001200220032004200520062007200820092010201120122013201420152016201720182019

Joonis 17. Valdkonnas „biograafia, genealoogia ja ajalugu“ ilmunud trükiraamatute nimetuste arv Eestis aastatel $2000-2019 .{ }^{68}$

${ }^{67}$ Andmed pärinevad põhiosas magistritööst: Kannik, T. Arhiivide kirjastustegevus Eestis, 36, joonis 1. Viimase kolme aasta andmeid on täiendatud arhiivide kodulehel oleva teabega. Arvestatud on kõiki teavikuid, v.a ajakirjad. Joonisel nimetatud kahe arhiivi kõrval teised väikesed arhiivid publitseerimisega ei tegele.

${ }^{68}$ Andmed on võetud Eesti Statistikaameti andmebaasist (http://andmebaas.stat.ee/Index.aspx?lang= et\&DataSetCode=KU12) seisuga 10.08.2020. 
tus, mille asutasid 1999. aastal ajaloolased Andres Adamson ja Lea Adamson. Ajalookirjanduse üllitamisel on aktiivsed samuti kirjastused Ilmamaa, Varrak, Tänapäev, Tammerraamat, EKSA, SE\&JS, Hea Lugu, Postimees jt. Eeskätt sõjaajaloo raamatutele on spetsialiseerunud kirjastus Grenader.

Uue sajandi üldine trend Eesti ajalooteaduses on kindlasti üha ulatuslikum publitseerimine välismaal, eeskätt inglise keeles. Seega vajab ülevaade Eesti ajaloolaste publitseerimispraktikast kindlasti Eestist kaugemale vaatamist. Kuivõrd kõigi Eesti ajaloolaste publikatsioonide kvantitatiivne analüüs eeldaks väga suurt eeltööd andmete koondamisel ja puhastamisel, siis piirdun järgnevas Tartu Ülikooli ajaloo ja arheoloogia instituudi (TÜ AAI) ning Tallinna Ülikooli ajaloo, arheoloogia ja kunstiajaloo keskuse (TLÜ AAK) töötajate publikatsioonide eritlusega. Kõik andmed pärinevad ETIS-est ja lähtuvad sellest, millise(d) asutuse(d) on autor ise oma publikatsiooniga sidunud. Andmed ei ole kindlasti lõpuni täpsed, kuid peaksid siiski andma ülevaate üldistest publitseerimise arengujoontest. ${ }^{69}$ Selguse huvides vaatlen eraldi monograafiaid (ETIS-e kategooriad 2.1 ja 2.2) ning teadusartikleid (ETIS-e $1.1,1.2,1.3$ ja 3.1).

Kui heita pilk kahe ülikooli ajaloolaste monograafiatoodangule, siis ilmus 2000.2019. aastani 155 monograafilist uurimust (joonis 18). Areng ei ole olnud sirgjooneline, ent seda pole ka põhjust eeldada. Üldise trendina saab siiski märgata mõõdukat kasvu, kusjuures rekordaastana tõuseb esile 2018, mil ilmus 17 monograafiat. Kui vaadata kahe ülikooli andmeid eraldi, siis võib näha, et mõlemad on panustanud monograafiate avaldamisse üsna võrdselt: TLÜ AAK töötajad avaldasid vaatlusalusel perioodil 87, TÜ AAI töötajad 68 teost (joonis 19). ${ }^{70}$

Kuivõrd teadussüsteemi surve on avaldada üha enam inglise keeles, siis on huvitav vaadata, mis keeles Eesti ajaloolased oma monograafiaid publitseerivad. Mõneti üllatuslikult on eesti keel endiselt valitsev, selles keeles on kirjutatud 73\% kõigist monograafiatest, järgneb inglise keel 13\% ja saksa keel 10\%-ga; lisaks on ilmunud üksikuid raamatuid vene, rootsi, soome, taani ja läti keeles (joonis 20).

Monograafiatelt teadusartiklite juurde liikudes kasvab nimetuste arv mõistagi hüppeliselt. Kui võtta arvesse artikleid ETIS-e kategooriates 1.1, 1.2, 1.3 ja 3.1, mis kõik eeldavad eelretsenseerimist või vähemalt ilmumist Eesti kultuurile olulistes ajakirjades, siis on kahe ülikooli ajaloolased avaldanud 2000.-2019. aastani 2017 teadusartiklit: TÜ AAI töötajad 1130 ja TLÜ AAK töötajad 887 artiklit. See on päris

${ }^{69}$ Andmed on asutuste kaupa automaatselt alla laetud ETIS-est, ent seejärel käsitsi puhastatud, s.t välja on jäetud kõik topeltkirjed, samuti need kirjed, mis ei vasta ETIS-e kategooriate nõuetele (nt 1.1, 1.2, 1.3 ja 3.1 artiklite seast on välja jäetud kõik raamatuarvustused, teadusürituste ülevaated, juubeliartiklid jm lühitekstid, mis ei ole käsitatavad teadusartiklina). Andmete valikus on arvestatud TÜ AAI ja TLÜ AAK institutsionaalsete eelkäijatega (TÜ ajaloo osakond ja TLÜ ajaloo instituut). Nimetan artiklis mõlema asutuse töötajaid lihtsuse mõttes ajaloolasteks, ent tegelikult on nende seas samuti arheolooge, kunstiajaloolasi ja etnolooge. Kõik ETIS-e väljavõtted on tehtud 01.08.2020 seisuga, mistõttu 2020. aasta publikatsioone ei ole arvestatud (aasta pole veel lõppenud).

${ }^{70}$ On oluline mainida, et publitseerimisnäitajad on esitatud absoluutarvudena, mitte suhtarvuna ühe töötaja kohta, mis annaks asutuse publitseerimisedukuse kohta adekvaatsema pildi. Paraku on asutuste isikkoosseisu dünaamikat arvestades statistika esitamine suhtarvudena väga keeruline, kui mitte võimatu. 


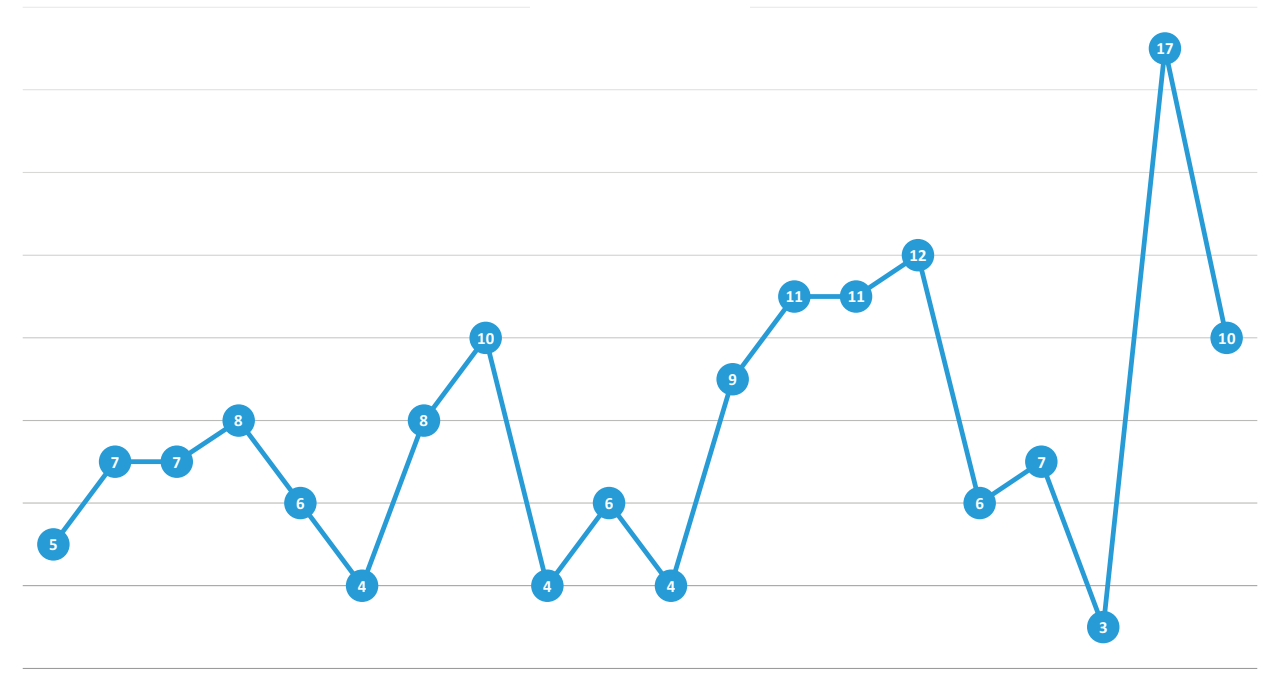

\begin{tabular}{llllllllllllllllllll}
\hline 2000 & 2001 & 2002 & 2003 & 2004 & 2005 & 2006 & 2007 & 2008 & 2009 & 2010 & 2011 & 2012 & 2013 & 2014 & 2015 & 2016 & 2017 & 2018 & 2019
\end{tabular}

Joonis 18. Tallinna Ülikooli ajaloo, arheoloogia ja kunstiajaloo keskuse ning Tartu Ülikooli ajaloo ja arheoloogia instituudi töötajate avaldatud monograafiate arv aastatel 2000-2019. ${ }^{71}$

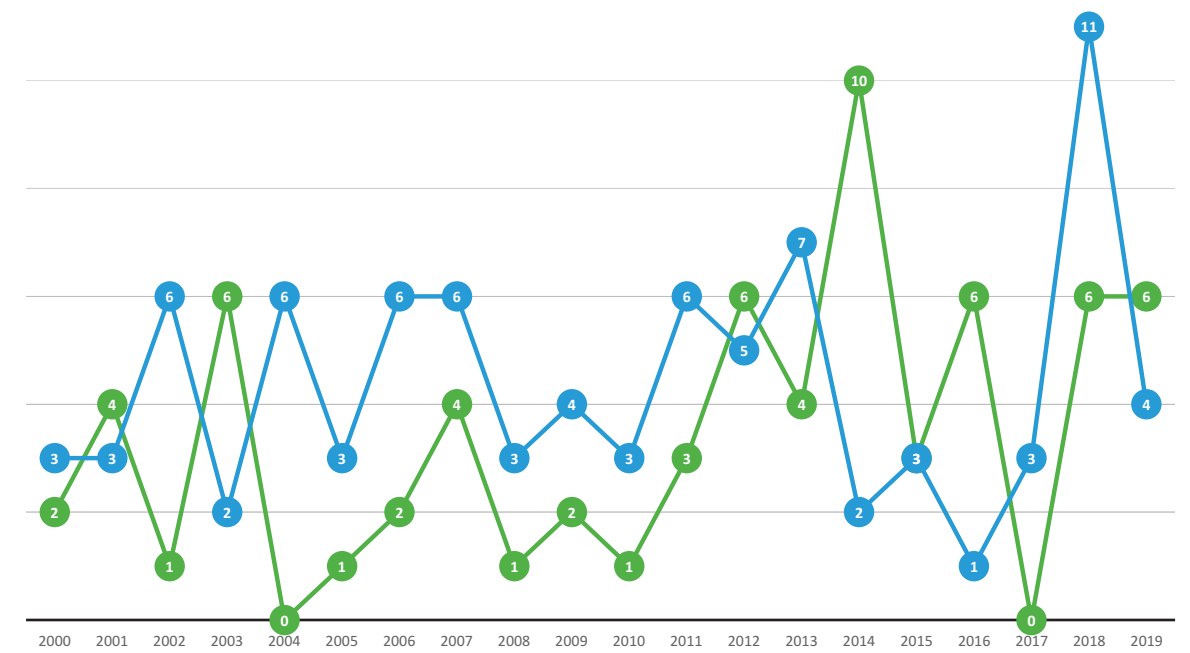

Joonis 19. Tallinna Ülikooli ajaloo, arheoloogia ja kunstiajaloo keskuse ning Tartu Ülikooli ajaloo ja arheoloogia instituudi töötajate avaldatud monograafiate arv eraldi esitatuna aastatel 2000-2019. ${ }^{72}$

${ }_{71}$ Andmed on võetud ETIS-est 01.08.2020. Andmete töötlemise kohta vt viide 69.

${ }^{72}$ Andmed on võetud ETIS-est 01.08.2020. Andmete töötlemise kohta vt viide 69. 


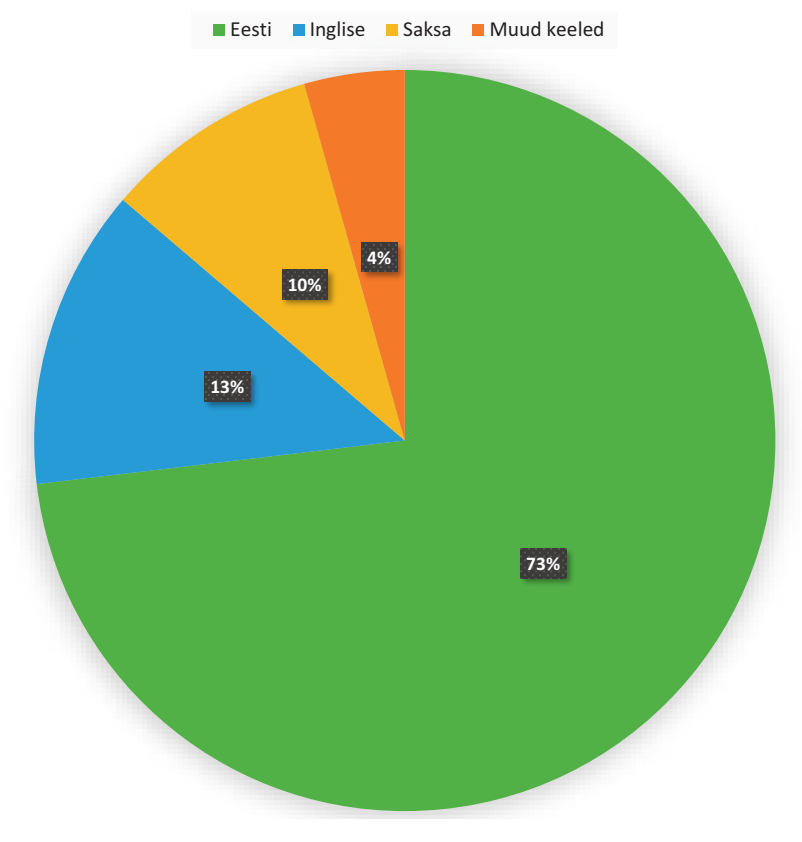

Joonis 20. Tallinna Ülikooli ajaloo, arheoloogia ja kunstiajaloo keskuse ning Tartu Ülikooli ajaloo ja arheoloogia instituudi töötajate avaldatud monograafiate keel aastatel 2000-2019. ${ }^{73}$

muljetavaldav hulk ja tähendab keskmiselt ühte uut teadusartiklit iga kolme päeva tagant. Aastate lõikes näeb publitseerimisdünaamikat ülikoolide kaupa joonisel 21. Torkab silma, et pikka aega avaldasid kahe asutuse töötajad artikleid üllatavalt võrdses tempos, ent teatav murdepunkt leidis aset 2015. aastal, millest alates on TLÜ AAK teadusproduktsioon hüppeliselt vähenenud. Seletus on tõenäoliselt seotud Tallinna Ülikooli 2015. aasta struktuurireformiga, mis päädis Ajaloo Instituudi senise iseseisva tegevuse lõpuga ja jätkamisega AAK nime all TLÜ humanitaarteaduste instituudi rüpes. Selle tulemusena lahutati senine Ajaloo Instituudi arheoloogiakogu koos töötajatega AAK-st. Olukorda pole lihtsustanud teadusrahastuse nappus, mis on sundinud viimastel aastatel AAK töötajaskonda vähendama.

Kuivõrd Eesti teadussüsteemis ei ole kõik teadusartiklid päris võrdse kaaluga, vaid kõige enam hinnatakse publikatsioone kategooriates 1.1 ja 3.1, siis olgu veel esitatud mõlema ülikooli ajaloolaste artiklitoodang kategooriate kaupa (joonis 22). Jooniselt jääb silma, et 1.1 artiklite hulk on hakanud üsna kiiresti tõusma viimase kümnendivahetuse paiku, ent selle taga ei pea ilmselt nägema üksnes suuremat aktiivsust ja edu rahvusvahelistes teadusajakirjades, vaid osaliselt ka tõsiasja, et sel ajal saavutas üha suurem hulk Eesti teadusajakirju 1.1 kategooria.

Kui lõpetuseks heita artiklitele pilk keele vaatenurgast, siis erinevalt monograafiatest võib siin täheldada selget liikumist inglise keele ülemvõimu poole (joonis 23). Kõikidest vaatlusalustest artiklitest on ilmunud inglise keeles 878 ehk 46\%, kus-

${ }^{73}$ Andmed on võetud ETIS-est 01.08.2020. Andmete töötlemise kohta vt viide 69. 


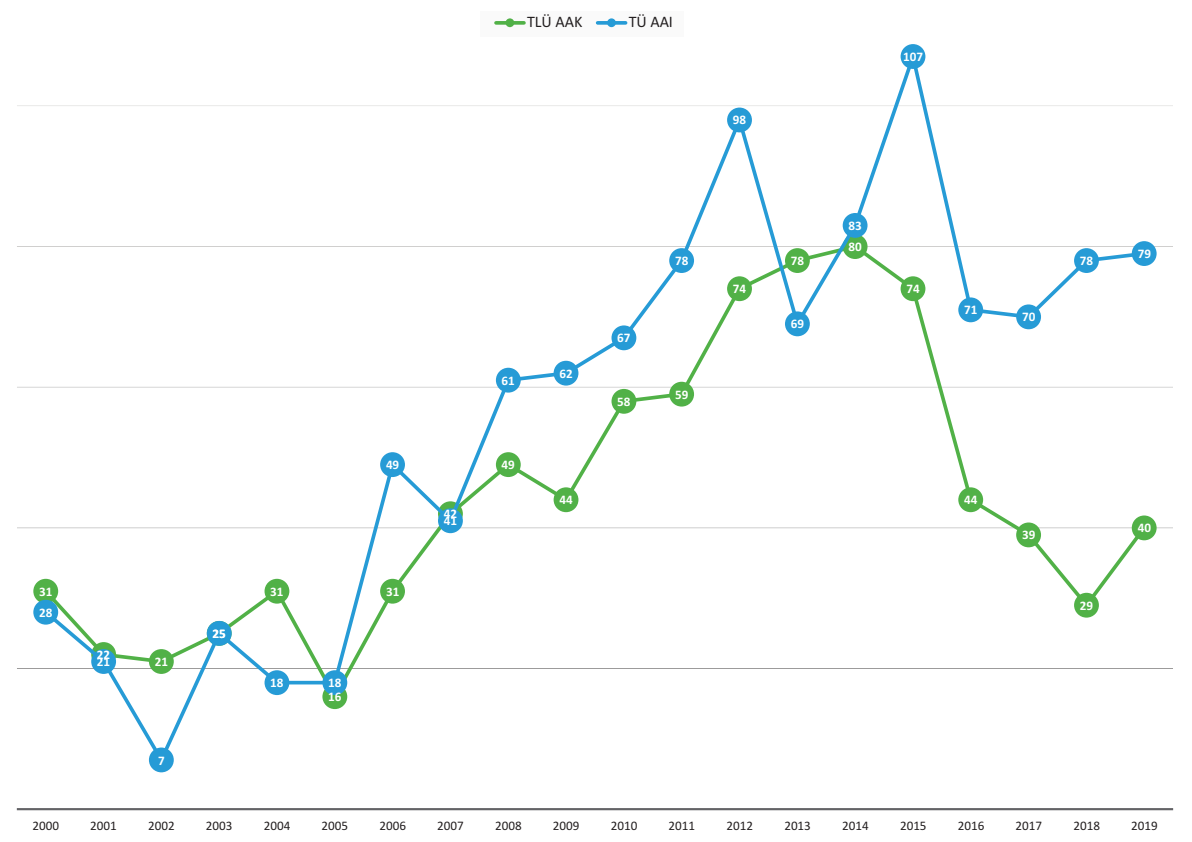

Joonis 21. Tallinna Ülikooli ajaloo, arheoloogia ja kunstiajaloo keskuse ning Tartu Ülikooli ajaloo ja arheoloogia instituudi töötajate avaldatud teadusartiklid aastatel 2000-2019 eraldi esitatuna. ${ }^{74}$

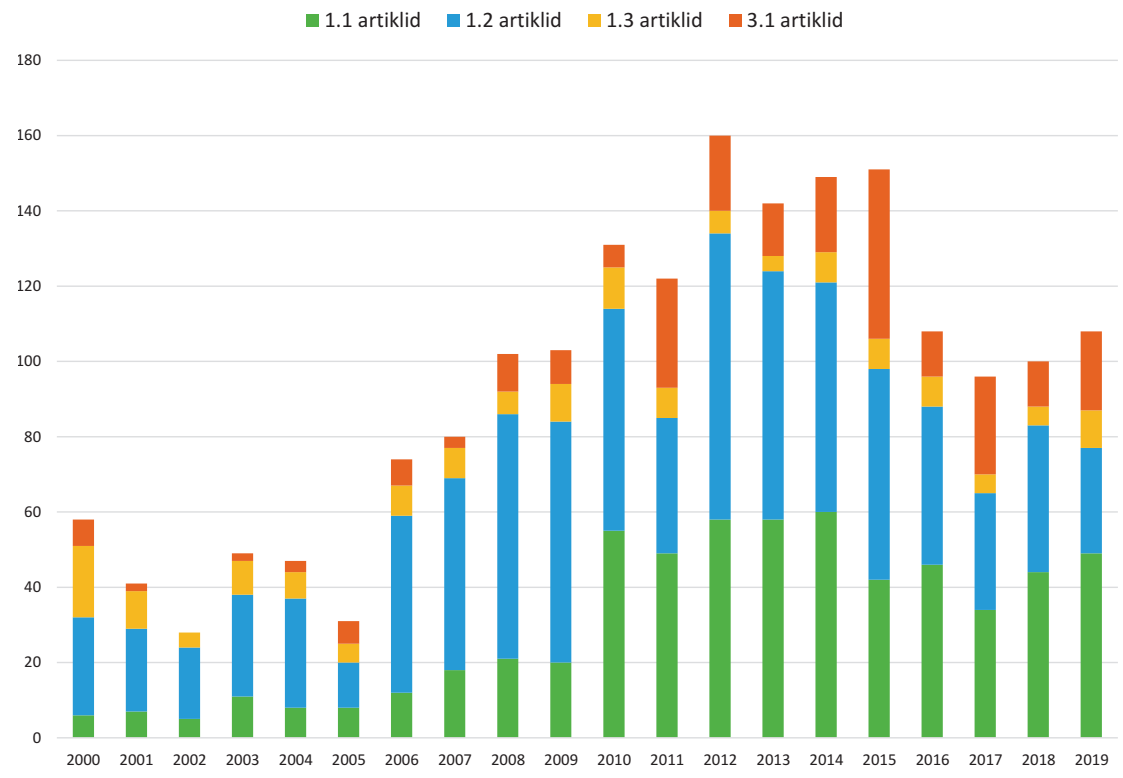

Joonis 22. Tallinna Ülikooli ajaloo, arheoloogia ja kunstiajaloo keskuse ning Tartu Ülikooli ajaloo ja arheoloogia instituudi töötajate avaldatud teadusartiklid aastatel 2000-2019 esitatud eraldi ETIS-e kategooriate järgi. ${ }^{75}$

${ }^{74}$ Andmed on võetud ETIS-est 01.08.2020. Andmete töötlemise kohta vt viide 69.

${ }^{75}$ Andmed on võetud ETIS-est 01.08.2020. Andmete töötlemise kohta vt viide 69. 


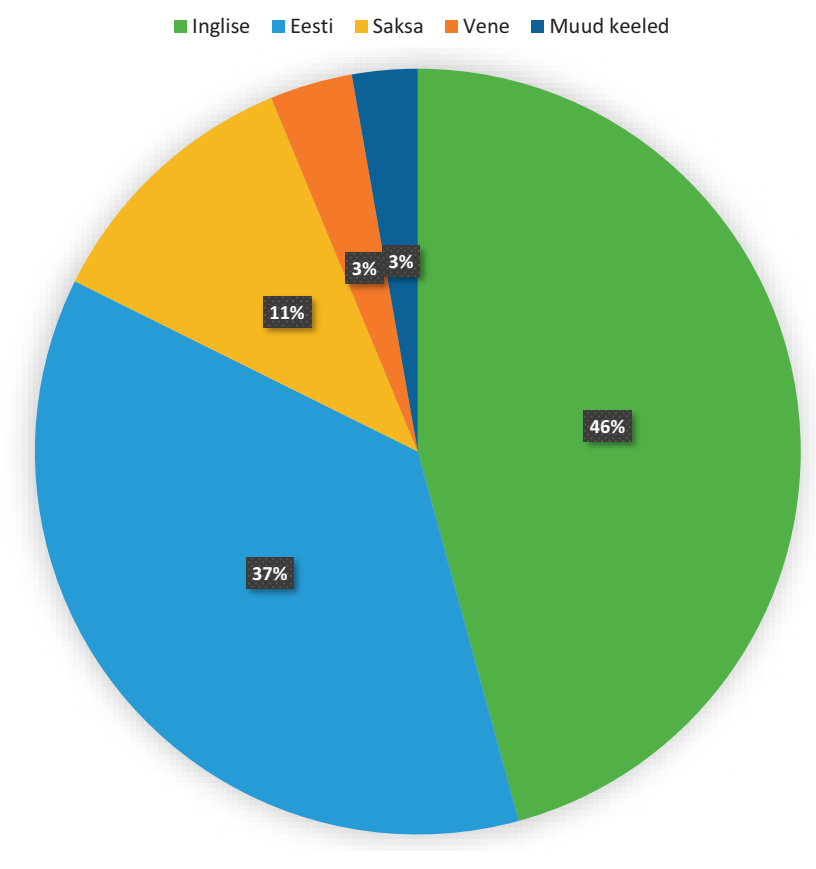

Joonis 23. Tallinna Ülikooli ajaloo, arheoloogia ja kunstiajaloo keskuse ning Tartu Ülikooli ajaloo ja arheoloogia instituudi töötajate avaldatud teadusartiklite keel aastatel 2000-2019. ${ }^{76}$

juures kõige enam on ingliskeelseid artikleid avaldatud just viimasel kümnel aastal. Eestikeelseid artikleid on kokku 702 ehk 37\% ja saksakeelseid 219 ehk 11\%. Lisaks on Eesti ajaloolased avaldanud artikleid vene keeles (67 ehk 3\%) ja veel kaheteistkümnes keeles (kokku 3\%). Mõistagi tuleb arvestada, et statistikas on kajastatud vaid n-ö kõrgema kategooria artiklid, mis ongi kõige sagedamini võõrkeelsed, alumistes kategooriates (ETIS-e $3.2 \mathrm{jt}$ ) prevaleerib endiselt eesti keel.

Visandatud ülevaade suutis loodetavasti piisava veenvusega näidata, et Eesti ajalooteadus on uuel sajandil läbi teinud tõelise kommunikatiivse plahvatuse. Vaid paari kümnendiga on publitseerimisvõimalused kasvanud eksponentsiaalselt - Eestis ilmub praegu kümmekond ajaloovaldkonna teadusajakirja või aastaraamatut, lisaks avaldavad pea kolmkümmend mäluasutust oma toimetiste sarja. Ilmub mitu populaarteaduslikku ajalooajakirja ja nii akadeemilised kui ka erakirjastused üllitavad igal aastal vähemalt poolsada algupärast ajalooraamatut. Eesti ajaloolased, arheoloogid ja kunstiajaloolased avaldavad nii kodustes kui rahvusvahelistes teadusväljaannetes vähemalt paarsada teadusartiklit aastas. Kõik see kokku lubab väita, et mitte kunagi varem pole ajalooteaduslik publitseerimine Eestis olnud nii aktiivne ja ulatuslik kui 21. sajandi esimestel kümnenditel.

\footnotetext{
${ }^{76}$ Andmed on võetud ETIS-est 01.08.2020. Andmete töötlemise kohta vt viide 69.
} 


\section{QUO VADIS, EESTI AJALOOTEADUS?}

Artikli lõpetuseks jõuan Eesti ajalooteaduse välispidise kirjelduse juurest veidi sisulisemate teemadeni ja püüan välja tuua mõned üldised arengujooned, mis minu hinnangul viimase paari kümnendi ajaloouurimise olukorda iseloomustavad. Kuigi vaatenurk on seekord subjektiivsem, siis ei säästa ma selleski alaosas lugejat päriselt arvandmetest.

Kui alustada küsimusega, mis teemad ja vaatenurgad on 21. sajandi Eesti ajalooteaduses siiani kõige tulemuslikumad olnud, siis üks viis sellele vastata on vaadata, milliseid uurimistöid on ajaloolased ise silmapaistvatena esile toonud. Selleks pakub hea võimaluse alates 1995. aastast mitme institutsiooni koostöös välja antav ajalookirjanduse aastapreemia, mille eesmärk on tunnustada kõige paremate eestikeelsete ajalooraamatute autoreid. ${ }^{77}$ Auhinnažürii on varieerunud aastati, ent koosnenud alati valdkonna hinnatud asjatundjatest. Alates 2000. aastast on auhinnaga pärjatud järgmisi teoseid:

2000 Veiko Berendsen, Margus Maiste. Esimene ülevenemaaline rahvaloendus Tartus 28. jaanuaril 1897

2001 Enn Küng. Rootsi majanduspoliitika Narva kaubanduse küsimuses 17. sajandi teisel poolel

2002 Keskus - tagamaa - ääreala: Uurimusi asustushierarhia ja võimukeskuste kujunemisest Eestis. Koostanud Valter Lang

2003 Jaak Valge. Lahtirakendamine: Eesti Vabariigi majanduse stabiliseerimine 1918-1924

2004 Indrek Jürjo. Liivimaa valgustaja August Hupel 1737-1819

2005 Eesti ajalugu VI: Vabadussõjast taasiseseisvumiseni. Peatoimetaja Sulev Vahtre, tegevtoimetajad Ago Pajur ja Tõnu Tannberg

2006 Rein Helme. Kindralfeldmarssal Barclay de Tolly

2007 Ea Jansen. Eestlane muutuvas ajas: Seisusühiskonnast kodanikuühiskonda

2008 Arvo Tering. Eesti-, liivi- ja kuramaalased Euroopa ülikoolides 1561-1798

2009 Inna Põltsam-Jürjo. Liivimaa väikelinn: Uus-Pärnu 16. sajandi esimesel poolel

2010 Eesti kunsti ajalugu 5. Koostanud Mart Kalm

2011 Aivar Jürgenson. Ladina rahva seas: Argentina ja sealsed eestlased

2012 Eesti ajalugu II: Eesti keskaeg. Koostanud Anti Selart

2013 Eesti ajalugu III: Vene-Liivimaa sõjast Põhjasõjani. Koostanud Enn Küng

2014 Piret Lotman. Heinrich Stahli elu ja looming

2015 Heiki Valk, Silvia Laul. Siksälä kalme

2016 Eesti kunsti ajalugu 6, 2. osa. Koostanud Jaak Kangilaski

2017 Jüri Kivimäe. Rektor Hans Kruus

77 2020. aasta seisuga osalevad ajalookirjanduse aastapreemia väljaandmisel Akadeemiline Ajalooselts, Eesti Ajaloomuuseum, Eesti Kunstiakadeemia kunstikultuuri teaduskond, Pärnu muuseum, Rahvusarhiiv, SA Haapsalu ja Läänemaa Muuseumid, Tallinna Linnaarhiiv, Tallinna Ülikooli humanitaarteaduste instituut, Tartu Linnamuuseum, Tartu Ülikooli ajaloo ja arheoloogia instituut ning Tartu Ülikooli muuseumid. 
2018 Heino Arumäe. Eesti ja Soome: sõjast sõjani

2019 Epi Tohvri. Georges Frédéric Parrot: Tartu Keiserliku Ülikooli esimene rektor

Sellest nimekirjast saab teha kindlasti erinevaid järeldusi ${ }^{78}$ ent mina tooksin välja järgmised kolm. Esiteks domineerivad selgelt ajaloouurimused, samas kui arheoloogilisi uurimistöid on nimekirjas vaid kaks ja kunstiajaloolisi üks (lisaks üks etnoloogi kirjutatud teos); väga võimalik, et põhjuseks on ennekõike ajaloolaste ülekaal žüriis. Teiseks näivad teistest edukuselt eristuvat kaks žanrit: monograafiline juhtumiuuring (kõige sagedamini ühest inimesest või konkreetsest piirkonnast) ja mahukas mitme autoriga üldkäsitlus (nagu „Eesti ajalugu“ või „Eesti kunsti ajalugu“"). Kolmandaks prevaleerivad nimekirjas uurimused traditsioonilistest ajaloovaldkondadest, nagu majandusajalugu, poliitiline ajalugu ja sotsiaalajalugu.

Huvi pärast võiks siia kõrvale tuua teisegi auhinnatud ajalooraamatute nimekirja, nimelt Eesti muuseumide aastaauhinna parima teadustrükise kategoorias, mida Kultuuriministeeriumi muuseuminõukogu algatusel antakse välja alates 2011. aastast:

2011 Tõnis Liibek, Ivar Leimus, Rein Loodus, Anu Mänd, Marta Männisalu, Mariann Raisma. Tallinna Suurgild ja gildimaja

2012 Elnara Taidre. Tõnis Vint ja tema esteetiline universum

2013 Linda Kaljundi, Tiina-Mall Kreem. Friedrich Ludwig von Maydelli pildid Baltimaade ajaloost

2014 Krista Sildoja. Äratusmäng uinuvale rahvamuusikale: August Pulsti mälestusi

2015 Tiina Jürgen, Ave Matsin. Mulgi rahvarõivad

2016 Garel Püüa, Tõnu Sepp, Ragnar Nurk. Kastellist kindluseks: Kuressaare linnus-kindluse ehituslugu uute väliuuringute valguses

2017 Oliver Orro, Maris Mändel, Robert Treufeldt. Kopli sonaat: Vene-Balti laevatehas

2018 Kalle Voolaid, Kaarel Antons. Eesti spordi lugu

2019 Mai Levin. Johann Köler

Ootuspäraselt on selles nimekirjas kõige enam esindatud kunsti- ja kultuuriajaloolised uurimused, samuti pole peetud paljuks tunnustada ka populaarteaduslikuma iseloomuga teoseid. Kindlasti on hindamisel silmas peetud ka auhinnatud raamatute väljanägemist, s.t eelistatud on suuremas formaadis ja rikkalikult illustreeritud teoseid. ${ }^{79}$

\footnotetext{
${ }^{78}$ Vt ka Tannberg, T. Zehn Jahre „Jahrespreis der estnischen Geschichtsschreibung“ (1996-2005). Forschungen zur baltischen Geschichte, 2006, 1, 191-194; Laur, M. Die estnische Geschichtsliteratur in den Jahren 2013 und 2014. - Forschungen zur baltischen Geschichte, 2015, 10, 319-329. Ajakiri Tuna avaldab igal aastal ka auhinnažürii pikema kommentaari finalistide ja laureaadi kohta.

${ }^{79}$ Olgu lisatud, et ajalookirjanduse auhindu jagatakse Eestis veel teisigi, näiteks Kaitseministeeriumi ja Eesti Sõjamuuseumi - Kindral Laidoneri Muuseumi Hendrik Sepa nimeline preemia silmapaistva Eesti sõjaajalooalase uurimuse autorile (alates 2013, vt https://esm.ee/uurimistoo/hendrik-sepa-preemia), Rahvusarhiivi tudengipreemia parimale arhiivinduslikule või arhiivimaterjalidele tuginevale üliõpilastööle (asutatud 1996, vt https://www.ra.ee/teadus-ja-publikatsioonid/rahvusarhiivi-tuden-
} 
Ajalookirjanduse aastapreemia nimekiri annab selge vihje, et 21. sajand on Eesti ajalooteaduses olnud üldkäsitluste kirjutamise aeg. See ei ole tingimata üllatav, sest sotsiaalne (kui mitte poliitiline) tellimus riigi ja rahva ajalooliste panoraamide järele on suur, samuti on üles kasvanud uus põlvkond ajaloolasi, kes on valmis seda tellimust täitma. Sümboolseks stardipauguks võib pidada Lennart Meri üleskutset 1999. aasta detsembris, eestikeelse ülikooli 80. aastapäeval, koostada Eesti rahvale uus Eesti ajalugu, mis jätkaks 1930. aastatel Hans Kruusi peatoimetatud sariväljaannet. Kakskümmend aastat hiljem on plaan edukalt ellu viidud, isegi ületatud; veel selle aasta lõpus peaks ilmuma sarja uus avaköide Eesti esiajaloost. ${ }^{80}$ Lisaks sellele kollektiivsele ettevõtmisele on uuel sajandil ilmunud aga ridamisi ühe mehe Eesti ajalugusid, isegi kui peamiselt välisautorite sulest. Neist kõige mahukam ja Eestiski kõrgelt hinnatud on Seppo Zetterbergi „Eesti ajalugu“, mis soome keeles ilmus 2007. aastal ja eesti keeles kaks aastat hiljem. ${ }^{81}$ Samal aastal tutvustas prantsuse lugejatele Eesti ajalugu Jean-Pierre Minaudier. ${ }^{82}$ 2018. aastal üllitas populaarse ingliskeelse lühiajaloo Neil Taylor ja seegi on jõudnud praeguseks eesti keelde..$^{83}$ Kuid ühe autori Eesti ajalugusid on uuel sajandil kirjutatud ka eesti keeles, pean ennekõike silmas Enn Tarveli „Eesti rahva lugu“ ${ }^{84}$ ent niisamuti Andres Adamsoni fragmentaarsemat ülevaadet „Eesti ajaloost viha, eelarvamuste ja valehäbita“, mõlemad $2018 .{ }^{85}$

Uueks arenguks sel sajandil võib pidada ka Eesti üldajaloolist käsitlust laiemas Baltimaade ajaloo kontekstis. Siin olid teedrajavad Andres Kasekampi ja Andrejs Plakansi raamatud esimese kümnendi lõpul, ${ }^{86}$ samuti veidi hilisem Norbert Angermanni ja Karsten Brüggemanni teos ${ }^{87}$ ent tõeliselt monumentaalseks võib pidada

gipreemia/) ja ajakirja Tuna artiklipreemia aasta parimale kaastööle (alates 2005). Välis-Eestis on 1976. aastast ebaregulaarselt välja antud Arthur Puksovi auhinda parimale ajaloouurimusele, mis käsitleb Eesti ajalugu muinasajast 1920. aastani. Vt Piirimäe, H. Eesti ajaloolaste ülemaailmne auhind: Dr. Arthur Puksovi auhind 2003. - Tuna, 2003, 3, 153-156.

${ }^{80}$ Eesti ajalugu II: Eesti keskaeg. Koost ja toim A. Selart. Tartu Ülikooli ajaloo ja arheoloogia instituut, Tartu, 2012; Eesti ajalugu III: Vene-Liivimaa sõjast Põhjasõjani. Koost ja peatoim E. Küng, kaastoim M. Seppel. Tartu Ülikooli ajaloo ja arheoloogia instituut, Tartu, 2013; Eesti ajalugu V: Pärisorjuse kaotamisest Vabadussõjani. Peatoim S. Vahtre tegevtoim T. Karjahärm, T. Rosenberg. Ilmamaa, Tartu, 2010; Eesti ajalugu IV: Põhjasõjast pärisorjuse kaotamiseni. Peatoim S. Vahtre, tegevtoim M. Laur. Ilmamaa, Tartu 2003; Eesti ajalugu VI: Vabadussõjast taasiseseisvumiseni. Peatoim S. Vahtre, tegevtoim A. Pajur, T. Tannberg. Ilmamaa, Tartu, 2005.

${ }^{81}$ Zetterberg, S. Viron historia. Suomalaisen Kirjallisuuden Seura, Helsinki, 2007; Zetterberg, S. Eesti ajalugu. Tlk M. Berg jt. Tänapäev, Tallinn, 2009.

${ }^{82}$ Minaudier, J.-P. Histoire de l'Estonie et de la nation estonienne. L'Harmattan, Paris, 2007.

${ }^{83}$ Taylor, N. Estonia: A modern history. Hurst \& Company, London, 2018; Taylor. N. Eesti ajalugu. Tlk L. Liiders. Rahva Raamat, Tallinn, 2020.

${ }^{84}$ Tarvel, E. Eesti rahva lugu. Varrak, Tallinn, 2017.

85 Adamson, A. Mida koolis ei õpetata: Eesti ajaloost viha, eelarvamuste ja valehäbita. Argo, Tallinn, 2018. Ei ole loetellu lisanud koolide tarbeks kirjutatud Eesti ajaloo ülevaateid, mida on minu teada sel sajandil valminud vähemalt kaks.

${ }^{86}$ Kasekamp, A. A history of the Baltic states. Palgrave Macmillan, Basingstoke, New York, 2010 (ee: Kasekamp, A. Balti riikide ajalugu. Tlk M. Laane. Varrak, Tallinn, 2011); Plakans, A. A concise history of the Baltic states. Cambridge University Press, Cambridge, 2011. Arheoloogia kontekstis oli esimene pääsuke: Lang, V. Baltimaade pronksi- ja rauaaeg. Tartu Ülikooli Kirjastus, Tartu, 2007.

87 Angermann, N., Brüggemann, K. Geschichte der baltischen Länder. Reclam, Ditzingen, 2018 (ilmumas peatselt ka eesti keeles). Vt ka Garleff, M. Die baltischen Länder: Estland, Lettland, Litauen 
Karsten Brüggemanni ja Ralph Tuchtenhageni koostatud kolmeköitelist koguteost „Das Baltikum: Geschichte einer europäischen Region“, millest siiani on ilmunud esimene ja kolmas köide. ${ }^{88}$

Üldajalugude kõrval on viimased paar kümnendit olnud soodsad ka spetsiifilisematele üldkäsitlustele. Nii on praegu valmimise lõppjärgus kuueosaline „Eesti kunsti ajalugu“", mille kõrval tuleb mainida ka Juhan Maiste kirjutatud „Eesti kunsti lugu“. 89 Ilmar Talve pani kirja „Eesti kultuuriloo“ .90 Välja on antud mahukas „Eesti spordi lugu“ ${ }^{91}$ samuti ,Eesti kiriku- ja religioonilugu“92 ning „Eesti linnaehituse ajalugu“ ${ }^{“ 93}$. Ilmavalgust on näinud „Eesti kooli ajaloo“ teine mahukas köide (esimene juba 1989). ${ }^{94}$ Arheoloogid kureerivad eesti- ja ingliskeelset sariväljaannet „Eesti arheoloogia“. ${ }^{95}$ Neljas kogukas köites avaldati hiljuti „Tallinna ajalugu“ ${ }^{96}$ Tõelise publitseerimisbuumi vallandas Eesti Vabariigi 100. aastapäev, mille raames avaldati üle 200 ajaloolise sisuga juubeliteose, sh 43-köiteline raamatusari „EV 100“.97

Kuid üldkäsitluste lokkamine ei tähenda, et viimased kümnendid poleks näinud tähelepanunihkeid ajalooperiooditi. Nagu kirjutavad siinsamas numbris Aivar Põldvee ja Marten Seppel, märgib uus sajand „varauusaja“ nimetuse kinnistumist Eesti

vom Mittelalter bis zur Gegenwart. Verlag Friedrich Pustet, Regensburg, 2001; Tuchtenhagen, R. Geschichte der baltischen Länder. Beck, München, 2005, 2. tr 2016.

${ }^{88}$ Das Baltikum: Geschichte einer europäischen Region, Bd. 1: Von der Vor- und Frühgeschichte bis zum Ende des Mittelalters. Hrsg. v. K. Brüggemann, D. Henning, K. Maier, R. Tuchtenhagen. Hiersemann, Stuttgart, 2018; Das Baltikum: Geschichte einer europäischen Region, Bd. 3: Die Staaten Estland, Lettland und Litauen. Hrsg. v. K. Brüggemann, R. Tuchtenhagen, A. Wilhelmi. Hiersemann, Stuttgart, 2020; Das Baltikum: Geschichte einer europäischen Region, Bd. 2: Vom Beginn der Frühen Neuzeit bis zur Gründung der modernen Staaten. Hrsg. v. K. Brüggemann, D. Henning, R. Tuchtenhagen. Hiersemann, Stuttgart (ilmumas 2021).

${ }^{89}$ Eesti kunsti ajalugu 2: 1520-1770. Koost ja toim K. Kodres. Eesti Kunstiakadeemia, Tallinn, 2005; Eesti kunsti ajalugu 3: 1770-1840. Koost ja toim J. Maiste. Eesti Kunstiakadeemia, Tallinn, 2017; Eesti kunsti ajalugu 4: 1840-1900. Koost ja toim J. Keevallik. Eesti Kunstiakadeemia, Tallinn, 2019; Eesti kunsti ajalugu 5: 1900-1940. Koost ja toim M. Kalm. Eesti Kunstiakadeemia, Tallinn, 2010; Eesti kunsti ajalugu 6, I osa: 1940-1991. Koost ja toim J. Kangilaski. Eesti Kunstiakadeemia, Tallinn, 2013; Eesti kunsti ajalugu 6, II osa: 1940-1991. Koost ja toim J. Kangilaski. Eesti Kunstiakadeemia, Tallinn, 2016; Maiste, J. Eesti kunsti lugu. Varrak, Tallinn, 2007.

${ }^{90}$ Talve, I. Eesti kultuurilugu: Keskaja algusest Eesti iseseisvuseni. Ilmamaa, Tartu, 2004

${ }^{91}$ Antons, K., Voolaid, K. Eesti spordi lugu. Eesti Spordi- ja Olümpiamuuseum, Tartu, 2018.

${ }^{92}$ Eesti kiriku- ja religioonilugu. Koost ja toim R. Altnurme. Tartu Ülikooli Kirjastus, Tartu, 2018. Vt ka Saard, R. Ristitud eestlane: Kristluse ajalugu Eestis keskajast tänapäevani. Argo, Tallinn, 2018.

${ }^{93}$ Eesti linnaehituse ajalugu: Keskajast tsaariaja lõpuni. Peatoim ja koost L. Hansar. Eesti Kunstiakadeemia, Tallinn, 2019.

${ }^{94}$ Eesti kooli ajalugu 2: 1860. aastaist 1917. aastani. Koost ja toim E. Laul, toim V. Varik. Teaduste Akadeemia Kirjastus, Tallinn, 2010.

${ }^{95} \mathrm{Vthttp}: / /$ www.arheo.ut.ee/teadus/sari-eesti-arheoloogia (11.08.2020). Seni on sarjas ilmunud kolm köidet, kõik viidatud lingil tasuta loetavad.

96 Tallinna ajalugu I: 1561. aastani. Koost ja peatoim T. Kala, toim T. Tamla. Tallinna Linnaarhiiv, Tallinn, 2019; Tallinna ajalugu II: 1561-1710. Koost L. Kõiv, peatoim T. Kala, toim T. Tamla. Tallinna Linnaarhiiv, Tallinn, 2019; Tallinna ajalugu III: 1710-1917. Koost T. Kala, L. Kõiv, O. Liivik, peatoim T. Kala, toim T. Tamla. Tallinna Linnaarhiiv, Tallinn, 2019; Tallinna ajalugu IV: 19172019. Koost O. Liivik, peatoim T. Kala, toim T. Tamla. Tallinna Linnaarhiiv, Tallinn, 2019.

${ }^{97}$ Vt Hiio, T. Eestlane-olemise verstaposte loendades: juubeleist veel. - Tuna, 2019, 3, 2-6. 
ajalookirjutuses ja selle perioodi intensiivsemat uurimist kui eales varem. Suuresti ootuspärane on nõukogude perioodi uuringute kasvav populaarsus, mis on seotud nii tekkinud ajalise distantsi, rahvusvahelise huvi kui ka rohke uurimisainesega, rääkimata siiani kummitavast mälutöö vajadusest. Mõneti ootamatum on keskaja uuringute kiire kasv ja rahvusvaheline silmapaistvus. ${ }^{98}$ Võib julgelt väita, et keskaja uurijate kogukond pole Eestis kunagi olnud nii suur ja aktiivne kui viimasel kahel kümnendil. See ei tähenda mõistagi, et ülejäänud perioodid oleks jäänud vaeslapse ossa, nagu saab veenduda siinsamas numbris perioodiülevaateid lugedes.

Üks näitaja uuritavate perioodide populaarsuse kohta, ja seda eriti pikemas perspektiivis, on kaitstud doktoritööde perioodieelistused. Eesti ajaloolased on aastatel 2000-2020 (sügis) kaitsnud Tartu ja Tallinna Ülikoolis 118 ajaloovaldkonna (hõlmab ajalugu, arheoloogiat ja kunstiajalugu) doktoritööd, neile saab lisada 26 välisülikoolides doktoriks väidelnut. ${ }^{99}$ Kui need 144 doktoritööd jaotada käsitletud ajalooperioodide kaupa, siis avaneb võrdlemisi kirev vaade (joonis 24). Selgeid trende on joonisel keeruline tuvastada, ent siiski torkab silma lähiajaloole pühendatud väitekirjade suur hulk (kokku 58 ehk 41\%), arvukuselt järgneb varauusaeg, mida käsitleb 27 väitekirja ehk 19\%, seejärel joonisel veidi meelevaldselt kokku pandud esi- ja vanaaeg (s.t peamiselt arheoloogide tööd, pluss mõned uurimused Vana-Lähis-Ida jm ajaloost), kus on kaitstud 22 dissertatsiooni ehk 15\%. Kohe kannul on keskaeg (19 tööd ehk 13\%) ja uusaeg (17 tööd ehk 12\%).

Keerulisem ja subjektiivsem on hinnata metodoloogilisi orientatsiooninihkeid käesoleva sajandi Eesti ajalooteaduses. Mõningatest uutest suundumustest annavad siin teemanumbris ülevaate Linda Kaljundi ja Aro Velmet. Kui aga vaadata n-ö kaotajate poolele, siis tundub, et selle sajandi suurim taanduja on 20. sajandi kõige mõjukam ajalooteaduse haru Eestis - agraarajalugu. Marten Seppel on selle hiljuti tabavalt kokku võtnud nii: „Kui 20. sajandi Eesti ajalookirjutust iseloomustas keskendumine agraarajaloo probleemidele, siis viimasel paarikümnel aastal on agraarajalugu jäänud vaeslapse ossa." ${ }^{100}$ Tõepoolest, kui vaadata näiteks kaitstud ajaloodissertatsioonide nimekirja, siis saab 144 doktoritööst liigitada agraarajaloo valdkonda vaid kaks. Seevastu oleme viimastel aastatel olnud tunnistajaks kasvavale huvile linnaajaloo vastu, mis eelmisel sajandil pälvis vaid üksikute entusiastide tähelepanu, ja sedagi peamiselt Tallinna näitel. ${ }^{101}$ Kui 20. sajandil huvitusid Eesti ajaloolased ennekõike poliitilisest, sotsiaal- ja majandusajaloost, siis sellel sajandil on

${ }^{98}$ Vt Mänd, A. Medieval studies in Estonia. - Annual of medieval studies at CEU. Ed. by J. A. Rasson, B. Z. Szakacs. CEU Press, Budapest, 2009, 221-230; Randla, A., Mänd, A. Keskaja visuaalkultuuri uurimisseisust Eestis ja Lätis. - Kunstiteaduslikke Uurimusi, 2016, 25, 1/2, 7-22. Vt ka Inna Põltsam-Jürjo ja Anti Selarti artiklit siinsamas ajakirjanumbris.

${ }^{99}$ Olen mõneti meelevaldselt jätnud arvestusest välja Eesti Kunstiakadeemias ning Eesti Muusika- ja Teatriakadeemias kaitstud ajalooainelised doktoritööd, kuivõrd rangelt võttes ei ole need kaitstud ajaloo õppekaval. Minu arvutuste kohaselt on perioodil 2000-2020 kaitstud EKA-s 12 kunstiajaloolist doktoritööd ja EMTA-s 3 muusikaajaloolist doktoritööd.

${ }^{100}$ Seppel, M. Väljasurev agraarajalugu. - Sirp, 05.09.2013.

${ }^{101}$ Vt Kreem, J. Was ist Stadtgeschichte in Estland? - Stadtgeschichte des Baltikums oder baltische Stadtgeschichte? Annäherungen an ein neues Forschungsfeld zur baltischen Geschichte. Hrsg. v. H. Hein-Kircher, I. Misāns. Verlag Herder-Institut, Marburg, 2016, 61-73. 


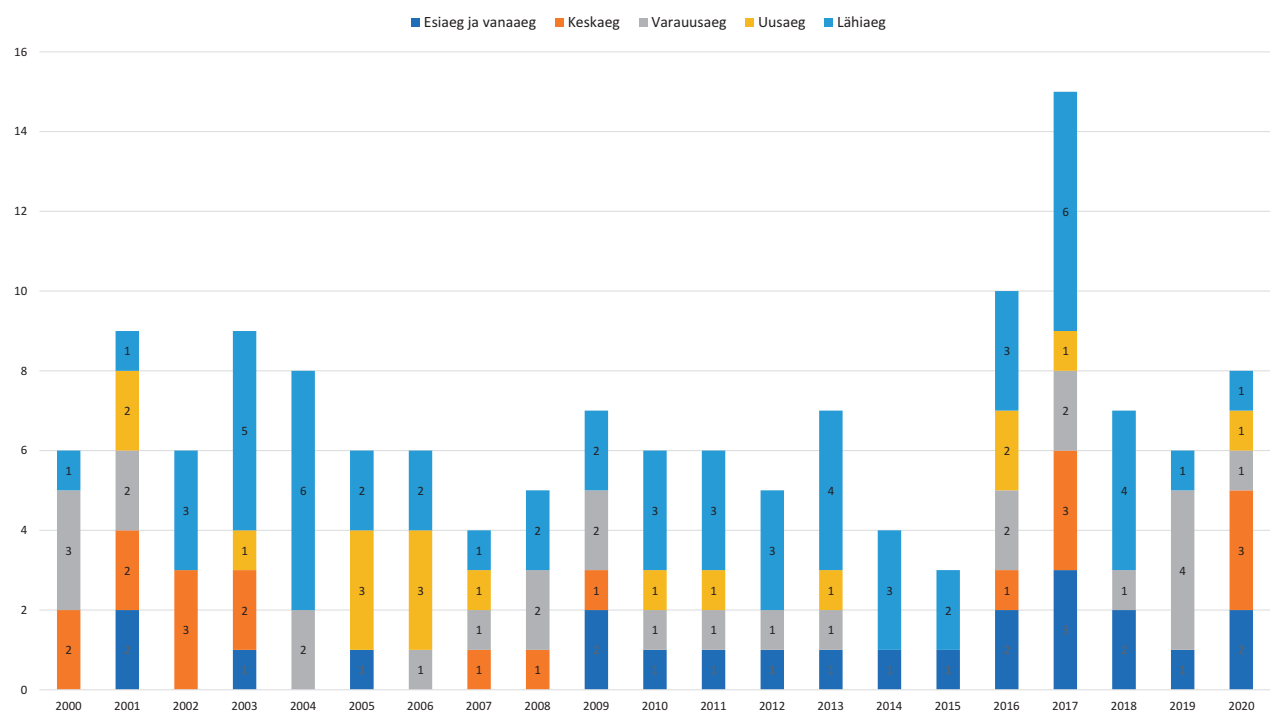

Joonis 24. Eestis ja välismaal kaitstud Eesti uurijate ajalooaineliste doktoritööde uurimisteemad periooditi aastatel 2000-2020. ${ }^{102}$

teinud kiire tähelennu avaralt mõistetud kultuuriajalugu, samuti selle sõiduvees ideede- ehk mõtteajalugu. ${ }^{103}$ Kui laenata üht vana metafoori prantsuse ajaloolaselt Michel Vovelle'ilt, siis võiks kujundlikult (ent lihtsustavalt) sedastada, et Eesti ajalooteadus on viimastel kümnenditel teinud läbi arengu „keldrist pööningule“. ${ }^{104}$

Ühe esmapilgul paradoksaalse arengujoone tahaksin veel välja tuua. Ühest küljest on uus sajand märkinud varem tihti ajaloo ,abiteaduste" või „eridistsipliinide“ rolli taandatud erialade, nagu arheoloogia, arhiivindus, etnoloogia ja kunstiajalugu, emantsipeerumist Eestis. Teisest küljest julgen aga arvata, et mitte kunagi varem pole ajaloouurimine olnud nii valdkondadevaheline kui viimastel aastatel. Esimese arengu ilmekad näited on institutsionaalsed nimemuutused: kunagisest ajaloo osakonnast on Tartu Ülikoolis saanud ajaloo ja arheoloogia instituut, samas kui Ajaloo

102 Andmed olen kogunud ise, peamisteks allikateks ETIS, ülikoolide kodulehed ja kolleegidelt saadud informatsioon. Arvestusse on lisatud ka need doktoritööd, mis on läbinud eelkaitsmise enne 01.08.2020. Doktoritööd, mille uurimisteema hõlmab pikemat ajavahemikku, liigitasin selle perioodi alla, mis on kaetud kõige mahukamalt. Esi- ja vanaajaks on loetud periood enne 1200. aastat, keskajaks 1200-1550, varauusajaks 1550-1800, uusajaks 1800-1900 ja lähiajaks 1900-2000. Tartu ja Tallinna Ülikoolis kaitstud doktoritööde kohta olid oluliseks allikaks järgmised artiklid: Laur, M. Dissertationen aus dem Fachbereich Geschichte der Universität Tartu seit 1991. - Forschungen zur baltischen Geschichte, 2006, 1, 184-190; Selart, A. Dissertationen aus dem Fachbereich Geschichte der Universität Tartu 2006-2015. - Forschungen zur baltischen Geschichte, 2016, 11, 215-221; Brüggemann, K. An der Universität Tallinn verteidigte Dissertationen zu historisch relevanten Themen 2000-2018. - Forschungen zur baltischen Geschichte, 2019, 14, 189-198.

${ }^{103}$ Vt Pärtel Piirimäe artiklit siinsamas ajakirjanumbris.

${ }^{104}$ Vovelle, M. De la cave au grenier: Un itinéraire en Provence au XVIIIe siècle, de l' histoire sociale à l'histoire des mentalités. S. Fleury, Québec, 1980. 
Instituut tegutseb nüüdsest nime all ajaloo, arheoloogia ja kunstiajaloo keskus. Lisaks on Tartu Ülikoolis endine etnoloogia õppetool saavutanud iseseisva osakonna staatuse sootuks teises instituudis. Muutused ei ole mõistagi üksnes nominaalsed, vaid kajastavad uut erialast eneseteadlikkust. Interdistsiplinaarse koostöö suurt kasvu on keerulisem lühidalt näidata, ent areng on olnud siiski silmatorkav, ja seda mitte ainult traditsiooniliste partnerite vahel humanitaarteaduste rüpes, vaid niisamuti loodusteadlastega (eriti arheoloogide koostöö geeniuurijate, keemikute jt-ga, kuid samuti keskkonnaajaloolaste koostöö bioloogide, klimatoloogide jt-ga). Väga võimalik, et see kahetine areng on aga paradoksaalne vaid näiliselt, tegelikult eeldabki viljakas interdistsiplinaarne koostöö tugevate distsipliinide olemasolu ja et ükski neist poleks allutatud teise abistajaks või teenindajaks.

Suurte avalike vaidluste vaates on 21. sajand Eesti ajalooteaduses olnud pigem rahulik. Oskan välja tuua vaid kaks debatti, mis pälvisid avalikkuse ulatuslikumat tähelepanu. Esiteks vaidlused Eesti esimese riigipea Konstantin Pätsi üle, eriti seoses tema tegevusega Teise maailmasõja eelõhtul. Need vaidlused puhus lõõmale Magnus Ilmjärve doktoritöö, mis eestikeelsel kujul ilmus lugejate ette 2004. aastal. ${ }^{105}$ Kuigi debatt kulges peamiselt meediaväljaannete veergudel, siis jätkus seda samuti akadeemilistesse ajakirjadesse, peamiselt tänu Jaak Valge panusele. ${ }^{106}$ Võib ilmselt pidada Eesti avalikkusele sümptomaatiliseks, et kui 2018. aastal ilmus kaheköiteline Konstantin Pätsi elulugu, mis hoidis teadlikult tasakaalukat joont, siis ei pälvinud see pea mingit laiemat huvi, samas kui tänavu suvel avaldatud endise ENSV KGB esimehe asetäitja polkovnik Vladimir Pooli raamat „Konstantin Päts vang $\mathrm{nr} 12$ “ on ajakirjanduse taas suurde elevusse viinud. ${ }^{107}$ Teine laiaulatuslikum debatt puhkes 2013. aasta alguses seoses „Eesti ajaloo“ teise, keskaja köitega. See vaidlus oli ennekõike õpetlik selles plaanis, et näitas ajaloo ootamatut aktuaalsust mitte pelgalt 20. sajandi traumaatiliste sündmuste, vaid niisamuti 13. sajandi sõjaliste ja kultuuriliste konfliktide osas. Mitu kuud väldanud debatt vääriks kindlasti distantsilt lähemat analüüsi, kuid kokkuvõttes võib seda käsitada ilmselt pärimusliku ja akadeemilise ajaloo kokkupõrkena identiteediloome tundlikel teemadel. ${ }^{108}$

${ }^{105}$ Ilmjärv, M. Hääletu alistumine: Eesti, Läti ja Leedu välispoliitilise orientatsiooni kujunemine ja iseseisvuse kaotus: 1920. aastate keskpaigast anneksioonini. Argo, Tallinn, 2004; 2. täiend. ja parand. $\operatorname{tr} 2010$.

${ }^{106}$ Valge, J. Konstantin Päts ja Nõukogude Liidu huvid I-II. - Akadeemia, 2007, 6, 1163-1200; 7, 1453-1484; Valge, J. Konstantin Päts, 12. märts ja Moskva. - Tuna, 2007, 2, 42-66; Valge, J. Veel kord Konstantin Pätsi suhetest Moskvaga. - Ajalooline Ajakiri, 2010, 1, 59-78; Valge, J. Top Estonian politician Konstantin Päts's financial dealings with Moscow. - Journal of Baltic Studies, 2012, 43, 4, 459-478. Vt ka Ilmjärv, M. Veel Konstantin Pätsist ja tema suhetest Nõukogude Liidu Tallinna saatkonnaga. Kas ainult Nõukogude diplomaatide silmade läbi? - Acta Historica Tallinnensia, 2009, 14, 62-101.

${ }^{107}$ Karjahärm, T. Konstantin Päts: Poliitiline biograafia I: Vabameelne opositsionäär (1874-1916). Rahvusarhiiv, Tartu, 2018, Pajur, A. Konstantin Päts: Poliitiline biograafia II: Riigimees (19171956). Rahvusarhiiv, Tartu, 2018; Pool, V. Konstantin Päts - vang nr 12. Tlk ja toim L. Virkus. Postimees, Tallinn, 2020.

108 Ühe retrospektiivse vaate veidi laiemas kontekstis pakub: Selart, A. Eestlaste oma ajalooteadus. Keel ja Kirjandus, 2018, 61, 1-2, 41-49. Vt ka Tarkiainen, K. Eesti keskaeg uues valguses. Tuna, 2013, 2, 131-138; Toomaspoeg, K. [Besprechung: Eesti ajalugu II: Eesti keskaeg. Hrsg. 
Väga võimalik, et 21. sajandi Eesti ajalooteaduse kõige pikema ja sügavama mõjuga arengumuutus pärineb aga hoopis tehnoloogiast ja seda võib püüda märksõnasse „digiteerumine“. Arvutite ja andmebaaside kasutamine ajaloouurimisel ei ole Eestis mõistagi uudis, pigem võiks väita, et Eesti ajalooteaduse esimene rahvusvaheline läbilöök pärinebki ajast - 1960.-1970. aastatest -, kui esimest korda läksid moodi kvantitatiivsed ja arvutuslikud meetodid. ${ }^{109}$ Võrdlemisi aktiivselt mindi Eestis 1990. aastatel kaasa ka digitehnoloogia uue lainega, kui näiteks meenutada Aadu Musta onomastikaprojekte ${ }^{110}$ ning Veiko Berendseni ja Margus Maiste ajaloolis-demograafilisi uuringuid. ${ }^{111}$ Kuid 21. sajandi digipööre on siiski märksa laiaulatuslikum ja mõjutab ajalooteaduse korraldust alusmüürideni välja (kui mõelda kas või digiarhiivinduse kiirele arengule, kultuuripärandi lausdigiteerimisele arhiivides, muuseumides ja raamatukogudes ning üha uutele andmekogudele). Tõsi, praegu on veel natuke vara hinnata, kui edukalt on Eesti ajaloolased, arhivaarid, arheoloogid, kunstiajaloolased jt digituultes toime tulnud, ent positiivseid näiteid leiab siiski arvukalt. Esile võib tuua Archaeovision OÜ ümber koondunud arheoloogide nii kodumaised kui ka rahvusvahelised projektid, ${ }^{112}$ Rahvusarhiivi edukad digitaalse ühisloome algatused ${ }^{113}$ ning kunstiajaloolaste ja konservaatorite

von Anti Selart. Tartu Ülikooli ajaloo ja arheoloogia instituut. Tartu 2012]. - Forschungen zur baltischen Geschichte, 2014, 9, 307-312. Vt ka Inna Põltsam-Jürjo ja Anti Selarti artiklit siinsamas ajakirjanumbris.

${ }^{109}$ Oluline oli siin Juhan Kahki panus, ent samuti Heldur Palli, Herbert Ligi jt oma. Vt nt Kahk, J. Elektronarvutite kasutamise võimalikkusest ajaloo uurimisel. - Eesti NSV Teaduste Akadeemia toimetised. Ühiskonnateaduste seeria, 1964, 4, lk 354-360; Kahk, J. Mathematics and complexity. - Times Literary Supplement, 1966, 3367, 803-804; Кахк, Ю. Нужна ли новая историческая наука. - Вопросы истории, 1969, 3, 41-54; Kahk, J. Application of computers and mathematical and statistical methods in studies carried out by Soviet historians. - Social Science Information, 1970, 9, 4, 81-90; Kahk, J. Computer analysis of socio-economic development in Estonia in the first half of the nineteenth century. - Mathematics in the archaeological and historical sciences. Ed. by F. R. Hodson; D. G. Kendall, P. Tăutu. Edinburgh University Press, Edinburgh, 1971, 500 504; Kahk J. New possibilities of using computerized historical analysis in the study of peasant households. - Turun Historiallinen Arkisto, 1973, 28, 375-389; Kahk, J. A propos de la politique agraire dans les régions baltes au cours des années 1840: Essai d'analyse du développement politique. - Annales: Histoire, Sciences Sociales, 1973, 28, 3, 817-837; Kahk, J. Recent results of Soviet historians in use of mathematical methods and computers in agrarian history. - Historisk Tidskrift, 1974, 94, 3, 414-421; Kahk, J., Kovalchenko, I. D. Methodological problems of the application of mathematical methods in historical research. - Historical Methods Newsletter, 1974, 7, 3, 217-224; Kahk, J. Quantitative historical research in Estonia: A case study in Soviet historiography. - Social Science History, 1984, 8, 2, 193-200.

${ }^{110}$ Must, A. Onomastika (I versioon 1995). - Rahvusarhiivi virtuaalne uurimissaal VAU, http://www.ra.ee/apps/onomastika/ (11.08.2020); vt ka Must, A. Komputeriseeritud ajaloouurimine Eestis maailmakonverentsi foonil. - Ajalooline Ajakiri, 1998, 4 (103), 15-24.

${ }^{111}$ Berendsen, V., Maiste, M. Esimene ülevenemaaline rahvaloendus Tartus 28. jaanuaril 1897. Eesti Ajalooarhiiv, Tartu, 1999.

${ }^{112} \mathrm{Vt} \mathrm{https://archaeovision.eu/et/} \mathrm{(11.08.2020).}$

${ }^{113} \mathrm{Vt} \mathrm{http://www.ra.ee/ilmasoda/;} \mathrm{http://www.ra.ee/vallakohtud/} \mathrm{ja} \mathrm{http://www.ra.ee/vabadussoda}$ (11.08.2020). Vt ka Mürk, M. Ühisloome esimesed sammud: algatus „Eestlased Esimeses maailmasõjas“. - Rahvusarhiiv 2013-2014. Koost T. Tannberg. Rahvusarhiiv, Tartu, 2015, 63-65; Too- 
palju tähelepanu pälvinud interdistsiplinaarsed uuringud visuaalkultuuri vallas. ${ }^{114}$ Kultuuripärandi digiteerimine on seatud viimasel kümnendil riiklikuks prioriteediks ja praegu kehtiv Kultuuriministeeriumi tegevuskava „Kultuuripärandi digiteerimine 2018-2023“ lubab: „1. Teha digitaalselt kättesaadavaks kuni kolmandik Eesti mäluasutuste kultuuripärandist. 2. Arendada välja digitaalse kultuuripärandi arhiveerimise, pikaajalise säilitamise ja varundamise konsolideeritud arhitektuur ning teenus. 3. Teha vähemalt kolmanda astme avaandmetena kättesaadavaks info 1,2 miljoni kultuuripärandi objekti kohta. " ${ }^{115}$ Siin pole koht ega võimalus, et Eesti ajalooteaduse digitaalset tulevikku pikemalt eritleda, ent isegi mõõdukalt optimistlike stsenaariumide puhul võib eeldada, et uurimisaine ulatuslik digiteerimine ning digitehnoloogiliste uurimisvahendite ja -meetodite kasutuselevõtt võib Eesti ajalooteadust järgmistel kümnenditel muuta enam, kui me seda praegu oskame ette näha. ${ }^{116}$ Kuid sellest saab täpsemalt kirjutada ilmselt juba kahekümne aasta pärast.

\section{TÄNUAVALDUS}

Tänan kõiki, kes aitasid täpsustada mitmesugust informatsiooni, mis artiklis on esitatud. Eraldi tänan ETAg-ist Maarja Sillastet, kes aitas koguda konkurentsipõhise teadusrahastuse andmeid. Samuti Tallinna Ülikoolist Maris Petersit ja Tartu Ülikoolist Kersti Roosimäed, kes aitasid täiendada andmeid üliõpilaste kohta. Viimaks suur tänu headele kolleegidele, kes olid lahkelt valmis läbi lugema artikli esimese versiooni ning esitama oma täpsustusi ja täiendusi: Toomas Hiio, Jüri Kivimäe, Krista Kodres, Valter Lang, Anu Mänd, Priit Pirsko, Anti Selart ja Marten Seppel. Vastutus võimalike vigade eest jääb mõistagi autorile.

ming, K. Ühisloomealgatus „Eestlased Esimeses maailmasõjas“ jõudis finišisse. - Rahvusarhiiv 2017-2018. Koost T. Tannberg, H. Tamman. Rahvusarhiiv, Tartu, 2019, 111-113.

${ }^{114}$ Vt http://rode.ekm.ee/ ja https://www.ackermann.ee/ (11.08.2020). Vt ka Hiiop, H., Randla, A. Medieval painted saints meeting modern media: Project: „Rode Altarpiece in Close-Up“. - Baltic Journal of Art History, 2014, 7, 171-180; Hiiop, H. What is under the paint layer of the Rode altarpieces. - Baltic Journal of Art History, 2015, 9, 239-253; Rode altar lähivaates = Rode altarpiece in close-up. Koost H. Hiiop, M. Kurisoo. Eesti Kunstimuuseum, Tallinn, 2016; Uueni, A., Apollonio, F. I., Hiiop, H. Photogrammetry and multispectral imaging for conservation documentation: Tools for heritage specialists. - New activities for cultural heritage. Ed. by M. Ceccarelli, M. Cigola, G. Recinto. Springer, Cham, 2017, 122-130.

$115 \mathrm{https}$ //www.kul.ee/sites/kulminn/files/kultuuriparandi_digiteerimine 2018-2023 tegevuskava luhiversioon_2020.pdf(11.08.2020).

${ }^{116}$ Vt Tamm, M., Pagi, H. Digiajaloo ja -arheoloogia uurimismeetodid. - Kuidas mõista andmestunud maailma? Metodoloogiline teejuht. Koost ja toim A. Masso, K. Tiidenberg, A. Siibak. Tallinna Ülikooli Kirjastus, Tallinn, 2020, 409-433; Tamm, M. Digitaalse ajalookultuuri sünd. - Postimees, 14.02.2020. Vt ka ajakirja Muuseum viimast teemanumbrit $(1,2020)$ „Digikultuur ja muuseum“, https://ajakiri.muuseum.ee/ journal/muuseum-nr-1-44-2020-digikultuur-ja-muuseum/ (11.08.2020). 


\title{
HISTORICAL RESEARCH IN ESTONIA IN THE TWENTY-FIRST CENTURY: AN INTRODUCTION
}

\author{
Marek TAMM
}

This is an introductory article for the special issue of Acta Historica Tallinnensia on historical studies in Estonia in the first two decades of the twenty-first century. The main aim of the article is to provide a quantitative and descriptive overview of the development and organisation of Estonian historical research in the last decades. The article is divided into five main topics.

First, the historical research is mapped from the perspective of researchers. An attempt is made to calculate the number of professional historians in Estonia, which is difficult both because of the lack of reliable statistical data and because of the difficulties in defining who can be considered a professional historian. However, it is proposed that there are up to 400 historians, widely defined, but less than a hundred who are actively engaged in research. In this context, the question of generation change is raised and examined on the basis of published Festschrifts. Then statistics about history students at Tartu and Tallinn Universities is provided over the last two decades and at three levels of study: $\mathrm{BA}, \mathrm{MA}$ and $\mathrm{PhD}$. The number of BA students in history has almost halved since 2012 as has the number of $\mathrm{PhD}$ students.

Secondly, the institutional organisation of historical research is examined. As in the late Soviet period, historical studies have two main centres in Estonia: Tartu and Tallinn, more specifically the Institute of History and Archaeology at the University of Tartu and the Institute of History, Archaeology and Art History at Tallinn University. A new important research centre for contemporary history is the Estonian Institute of Historical Memory, established in 2008. Traditionally, historical archives have played a major role in historical research. By far the most important archival institution is the National Archives of Estonia (re-established in 1999, reorganised in 2012). Especially in the context of medieval and early modern studies, Tallinn City Archives should also be mentioned. The third main institutional pillar of historical research is formed by the museums. There are currently 180 museums in Estonia, with 244 places to visit, and within these, 49 history and archaeology museums. Finally, the role of academic libraries in historical research is briefly discussed. Next to institutions, various associations have important roles in the field of historical studies. The main organisation of historians is the Estonian Academic Society of History (re-established in 1999). But even more active and influential are the Estonian Association of Archivists (re-established in 1989) and the Estonian Museum Association (established in 1988). There are in total about ten historical societies or associations in Estonia, in various branches of historical studies (from art history and archaeology to military and church history).

Thirdly, the financing of historical research is addressed, with a focus on competition-based funding. A new system of research grants was introduced in early 1990s, and since 2012 grant funding has been organised by the Estonian Research Council. 
The article offers a statistical overview of the research grants given in the fields of history, archaeology and art history over the last two decades, both in numbers and in monetary terms. While in terms of money the rise has been significant in the last decades, in terms of numbers there has been a decline of grants since the early 2010s. The most revealing number is the success rate of grant applications in the aforementioned three fields: up to 2015 the average success rate was about 20-30\%, but during the last five years it has dropped to 6-14\%, with a small rise in 2020. In other words, there has been a clear underfunding of historical research in the past five years, seriously undermining the sustainability of historical studies in Estonia.

Fourthly, the main communication channels of historians in Estonia and their publishing practices are discussed. Since the turn of the century, there has been a boom in historical periodicals in Estonia. Three new history journals were established in late 1990s: Acta Historica Tallinnensia (1997), Tuna (1998) and Ajalooline Ajakiri (1998). In addition, many more specific periodicals were launched, including Eesti Arheoloogia Ajakiri (1997), Archaeological Fieldwork in Estonia (1997), Kunstiteaduslikke Uurimusi (reorganised as a periodical in 2002), Forschungen zur baltischen Geschichte (2006), the Baltic Journal of Art History (2009). In addition, Estonian museums and archives are very active in the field of publishing. There are, for instance, about thirty regular series of yearbooks or proceedings, and also quite a few book series, published by various memory institutions. As to publishing practices, a statistical overview of the research output of historians (widely defined) in Tallinn and Tartu University is presented. Over the last twenty years, 155 monographic studies have been published (73\% written in Estonian, 13\% in English and $10 \%$ in German). Between 2000 and 2019, historians of both universities have published in total 2017 research papers (in peer-reviewed journals and edited volumes, corresponding to the categories of 1.1, 1.2, 1.3 and 3.1 of the Estonian Research Council). Forty-six percent of the articles were published in English, 37\% in Estonian and $11 \%$ in German.

Fifthly, and finally, some general trends in historical research in Estonia are briefly analysed. There has been a decline in agrarian history in this century, while urban and cultural history have become more popular than ever. A great number of general histories have been published in recent decades, including a major six-volume History of Estonia, a six-volume Estonian Art History and a four-volume History of Tallinn. In terms of historical periods, there has been new interest in the early modern period, although contemporary history is clearly the dominant field of study. Somehow surprisingly, medieval studies have also gained new important ground. In $\mathrm{PhD}$ dissertations over the last two decades, $41 \%$ of the theses were dedicated to contemporary history, $19 \%$ to early modern history, $15 \%$ to pre- and ancient history, $13 \%$ to medieval history and $12 \%$ to modern history. The most important and longterm change in Estonian historical research is probably the 'digital turn', i.e. the massive digitisation of historical documents and cultural heritage as well as the introduction of new digital research methods. It is highly probable that this trend will continue to shape prominently the landscape of historical studies in Estonia in the next two decades. 